\title{
Synthesis and Reactivity of Iron Complexes with a Biomimetic SCS Pincer Ligand
}

\author{
Amy L. Speelman, Kazimer L. Skubi, Brandon Q. Mercado, and Patrick L. Holland* \\ * = corresponding author; email: patrick.holland@yale.edu \\ Department of Chemistry, Yale University, 225 Prospect Street, New Haven, Connecticut 06520, United \\ States
}

\section{Table of Contents}

General Information $\quad$ S2

Ligand synthesis $\quad$ S4

NMR spectra of ligands and synthetic intermediates $\quad$ S8

Supplemental experiments for ligand synthesis $\quad S 16$

Synthesis and characterization of iron complexes with $\mathbf{S}^{\mathrm{Me}} \mathbf{C S}^{\mathrm{Me}} \quad \mathrm{S} 19$

$\begin{array}{ll}\mathrm{N}_{2} \text { reduction attempts with compound } 8 & \mathrm{~S} 27\end{array}$

Synthesis and characterization of iron complexes with $\mathbf{S C S}^{2-} \quad$ S28

Mössbauer studies on protonation of compound $10 \quad S 45$

$\begin{array}{ll}\mathrm{N}_{2} \text { reduction attempts with compound } 10 & \text { S49 }\end{array}$

Thermal decomposition of $12 \quad S 50$

$\begin{array}{ll}\text { Crystallographic details } & \text { S51 }\end{array}$

References $\quad$ S63 


\section{General Information}

All syntheses were performed under nitrogen or argon atmosphere in MBraun or Vigor gloveboxes maintained at or below $1 \mathrm{ppm}$ of $\mathrm{O}_{2}$, or using standard Schlenk techniques under nitrogen atmosphere unless otherwise noted. Glassware was either flame-dried or dried in an oven at $150{ }^{\circ} \mathrm{C}$ overnight. Molecular sieves, alumina, and Celite were dried overnight at $200^{\circ} \mathrm{C}$ under vacuum.

\section{Sources of materials}

All solvents and reagents were purchased from commercial suppliers and used as received, except as follows:

Solvents used for air- and moisture-sensitive reactions: Pentane, hexanes, benzene, toluene, and diethyl ether were purified by passage through activated alumina and Q5 columns and stored over $4 \AA$ molecular sieves. THF was distilled from a potassium benzophenone ketyl solution under argon and stored over $4 \AA$ molecular sieves. For manipulations of iron complexes, THF was also passed through a plug of activated alumina immediately before use. Acetonitrile was degassed with argon, dried using a Pure Process Technology solvent system, and stored over $3 \AA$ molecular sieves.

NMR solvents: $\mathrm{C}_{6} \mathrm{D}_{6}$ was dried over activated alumina and sparged with argon, and THF- $\mathrm{d}_{8}$ was vacuum transferred from potassium benzophenone keyl; both were stored over $4 \AA$ molecular sieves. $\mathrm{CD}_{3} \mathrm{CN}$ was vacuum transferred from $\mathrm{CaH}_{2}$ and stored over $3 \AA$ molecular sieves.

Purified materials: Methyl iodide and benzyl bromide were purified by passage through a plug of activated alumina. Naphthalene was sublimed under vacuum. KHMDS was crystallized from toluene. 2,6-di-tertbutyl-4-methoxyphenol (BHT) and 18-crown-6 were dissolved in dry diethyl ether or pentane and stored over molecular sieves for at least 24 hours, then filtered through Celite and dried under vacuum.

Synthesized materials: $\mathrm{Fe}(\mathrm{OTf})_{2}(\mathrm{MeCN})_{2}$ was generated by precipitating $\mathrm{Fe}(\mathrm{OTf})_{2}$ (Strem) from an acetonitrile solution with diethyl ether. ${ }^{1} \mathrm{Fe}(\mathrm{HMDS})_{2}(\mathrm{THF})_{n}$ was synthesized following a literature procedure and THF content was quantified using ${ }^{1} \mathrm{H}$ NMR spectroscopy. ${ }^{2}$ Potassium on graphite $\left(\mathrm{KC}_{8}\right)$ was prepared by heating stoichiometric amounts of potassium and graphite at $140^{\circ} \mathrm{C}$ under argon atmosphere. ${ }^{3}$ Caution: Both $\mathrm{KC}_{8}$ and $\mathrm{Fe}(\mathrm{HMDS})_{2}$ can ignite on contact with air, and care must be taken during their synthesis and handling. 2,2",4,4",6,6"--Hexamethyl-[1,1':3',1"-terphenyl]-2'-thiol ${ }^{4},\left[\mathrm{H}\left(\mathrm{OEt}_{2}\right)_{2}\right]\left[\mathrm{BAr}^{\mathrm{F}}\right]^{5},\left[\mathrm{Ph}_{2} \mathrm{NH}_{2}\right][\mathrm{OTf}]^{6}$, and $\left[\mathrm{HNEt}_{3}\right]\left[\mathrm{PF}_{6}\right]^{7}$ were synthesized following literature procedures.

\section{Spectroscopic measurements}

${ }^{1} \mathrm{H},{ }^{13} \mathrm{C}$, and ${ }^{19} \mathrm{~F}$ NMR spectra were recorded on Agilent DD2 400, 500, or $600 \mathrm{MHz}$ NMR spectrometers at $25{ }^{\circ} \mathrm{C}$ except where noted. Chemical shifts for ${ }^{1} \mathrm{H}$ and ${ }^{13} \mathrm{C}\left\{{ }^{1} \mathrm{H}\right\}$ spectra are referenced to $\mathrm{SiMe}_{4}$ using the residual protiated solvent peaks as internal standards. ${ }^{19} \mathrm{~F}$ spectra were absolute referenced to the corresponding ${ }^{1} \mathrm{H}$ spectra.

UV-Visible spectra were recorded in $1 \mathrm{~mm}$ pathlength cells on a Cary 60 spectrophotometer at ambient temperature.

IR spectra were recorded on a Bruker ALPHA FT-IR spectrometer equipped with a platinum-ATR attachment.

Mass spectrometric measurements were performed with a Waters Xevo QToF LC-MS system, equipped with a Waters Acquity UPLC system. $3 \mu \mathrm{L}$ of each solution were injected into a sample loop and separated on a Waters Acquity UPLC BEH C18 $1.7 \mu \mathrm{m}, 2.1 \times 50 \mathrm{~mm}$ Column, equilibrated at $30 \mathrm{deg} C$ in the column department of the LC system. $A$ binary gradient was used: Solvent $A=$ Water, HPLC grade Chromasolv, with $0.1 \%$ Formic Acid; Solvent B = Acetonitrile, HPLC grade Chromasolv, with $0.1 \%$ Formic Acid. Flow 
was held constant at $0.600 \mathrm{~mL} / \mathrm{min}$ and the composition of the eluent was changed according to the following gradient:

0 to $0.4 \mathrm{~min}$, held at $95 \% \mathrm{~A}, 5 \% \mathrm{~B}$

0.4 to 2 min, change to $5 \% \mathrm{~A}, 95 \% \mathrm{~B}$

2 to $3 \mathrm{~min}$, held at $5 \% \mathrm{~A}, 95 \% \mathrm{~B}$

3 to 3.01 min, change to $95 \%$ A, $5 \%$ B

3.01 to $5 \mathrm{~min}$, held at $95 \%$ A, $5 \%$ B

The ionization source was run in ESI mode, with the electrospray needle held at $+3 \mathrm{kV}$.

Cone Gas was held at $24 \mathrm{~L} / \mathrm{h}$, Desolvation Gas at $720 \mathrm{~L} / \mathrm{h}$ and $250 \mathrm{deg} \mathrm{C}$ and the source was held at $125 \mathrm{deg}$ C. Mass spectra were recorded in the range of 100 to $2000 \mathrm{~m} / \mathrm{z}$ in positive ion mode. Measurements and data post-processing were performed with MassLynx 4.1 VSN 719.

Elemental analyses were performed at the CENTC Elemental Analysis facility at the University of Rochester or by Midwest Microlabs.

Mössbauer data were recorded on a See Co. MS4 Mössbauer spectrometer with alternating constant acceleration integrated with a Janis SVT-400T He/ $\mathrm{N}_{2}$ cryostat with a $50 \mathrm{mT}$ applied magnetic field. All measurements were performed at $80 \mathrm{~K}$. Isomer shifts were determined relative to $\alpha-F e$ at $298 \mathrm{~K}$. Mössbauer spectra were fit to Lorentzian doublets using the program WMoss (SEECo). Mössbauer spectra for 8 and 9 were recorded on 30-40 mg of compound with natural abundance Fe. Spectra for 10 - 13 were recorded on $5-10 \mathrm{mg}$ of compound enriched with $20 \%{ }^{57} \mathrm{Fe}$. 


\section{Ligand Synthesis}

\section{Synthetic procedures}

Except where explicitly noted, all syntheses were performed under inert atmosphere. Compounds 2 - 4 were synthesized as described in the literature ${ }^{8-10}$ with minor modifications. The ${ }^{1} \mathrm{H}$ NMR spectra of $1-4$ match those reported in the literature. The synthetic procedures and ${ }^{1} \mathrm{H}$ NMR spectra are provided here for the reader's convenience. The new compounds $5-7$ are additionally characterized by ${ }^{13} \mathrm{C}$ NMR spectroscopy and high-resolution mass spectrometry.

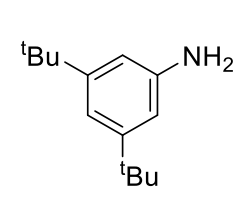

Synthesis of $1 .{ }^{11-12} \mathrm{In}$ an $\mathrm{N}_{2}$-filled glovebox, $25.35 \mathrm{~g}(94.2 \mathrm{mmol}) 3,5$-di-tert-butyl bromobenzene and $17.34 \mathrm{~g}$ (104 mmol, $1.1 \mathrm{eq})$ lithium bis(trimethylsilyl)amide were combined in $300 \mathrm{~mL}$ of toluene in a Schlenk flask. A pre-mixed solution of $270.6 \mathrm{mg}(0.47$ $\mathrm{mmol}, 0.005 \mathrm{eq}) \mathrm{Pd}(\mathrm{dba})_{2}$ and $165.3 \mathrm{mg}(0.47 \mathrm{mmol}, 0.005$ equiv) CyJohnPhos in $10 \mathrm{~mL}$ toluene was added. The Schlenk flask was placed under $\mathrm{N}_{2}$ on a Schlenk line and transferred to an oil bath pre-heated to $100^{\circ} \mathrm{C}$. After 1 hour, the flask was removed from heat and cooled to room temperature. Subsequent workup steps were performed in air. The reaction mixture was diluted with $300 \mathrm{~mL}$ of diethyl ether, then stirred with $500 \mathrm{~mL}$ of $1 \mathrm{M}$ aqueous $\mathrm{HCl}$ for 30 minutes. The aqueous and organic layers were separated, and the organic layer was stirred with $500 \mathrm{~mL}$ of $2.5 \mathrm{M}$ aqueous $\mathrm{KOH}$ for 30 minutes. The aqueous and organic layers were separated, and the organic layer was dried over sodium sulfate. The solvent was removed via rotary evaporation, affording the title compound as a waxy brown solid. This compound contains a colored impurity not visible by ${ }^{1} \mathrm{H}$ NMR spectroscopy that was not removed because it does not impact the subsequent step. Yield: $18.86 \mathrm{~g}$ (98\% yield).

${ }^{1} \mathrm{H} \mathrm{NMR}\left(\mathrm{CDCl}_{3}, 400 \mathrm{MHz}\right): 6.85(\mathrm{t}, J=1.6 \mathrm{~Hz}, 1 \mathrm{H}), 6.57(\mathrm{~d}, J=1.6 \mathrm{~Hz}, 2 \mathrm{H}), 3.58(\mathrm{~s}, 2 \mathrm{H}), 1.29(\mathrm{~s}, 18 \mathrm{H})$ ppm.<smiles>Nc1nc2cc(Br)cc(Br)c2s1</smiles>

Synthesis of 2..$^{8-9}$ This reaction was performed entirely in air. In a round-bottomed

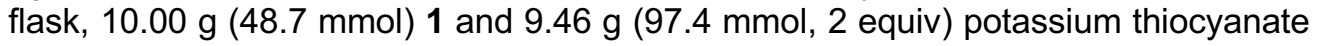
were combined in $85 \mathrm{~mL}$ glacial acetic acid. While stirring the resulting slurry, a solution of $2.5 \mathrm{~mL}$ (48.5 mmol, 1 eq) $\mathrm{Br}_{2}$ in $10 \mathrm{~mL}$ glacial acetic acid was added dropwise over 45 minutes. After an hour, the solvent was removed under vacuum giving an orange tar. Methanol $(200 \mathrm{~mL})$ was added, and the resulting mixture was stirred to produce a red solution with an orange solid. The suspension was filtered through Celite, and $5 \mathrm{M} \mathrm{KOH}$ was added to the filtrate until the solution became weakly alkaline. Water $(400 \mathrm{~mL})$ was added, resulting in the formation of a white suspension. The suspension was extracted with $400 \mathrm{~mL}$ of dichloromethane. The organic layer was shaken with brine, dried over sodium sulfate, and filtered. The solvent was removed via rotary evaporation, and the resulting red solid was triturated with pentane to afford the title compound as a white solid. Yield: $11.22 \mathrm{~g}$ (88\% yield).

${ }^{1} \mathrm{H} \mathrm{NMR}\left(\mathrm{CDCl}_{3}, 400 \mathrm{MHz}\right): 7.49(\mathrm{~d}, J=1.7 \mathrm{~Hz}, 1 \mathrm{H}), 7.20(\mathrm{~d}, J=1.7 \mathrm{~Hz}, 1 \mathrm{H}), 5.30(\mathrm{~s}, 2 \mathrm{H}), 1.45(\mathrm{~s}, 9 \mathrm{H})$, $1.36(\mathrm{~s}, 9 \mathrm{H}) \mathrm{ppm}$.<smiles>Nc1cc(Br)cc(Br)c1S</smiles>

Synthesis of 3 and $4 .{ }^{8}$ In a round-bottomed flask equipped with a Claisen adapter and a condenser, $10.00 \mathrm{~g}(38.1 \mathrm{mmol})$ of 2 was suspended in $110 \mathrm{~mL}$ of 2,3-butanediol. The flask was evacuated and the suspension was stirred under dynamic vacuum for 15 minutes to remove dioxygen. The reaction setup was refilled with $\mathrm{N}_{2}$, and $86.02 \mathrm{~g}(1.53 \mathrm{~mol}, 40$ equiv) of potassium hydroxide was quickly added under $\mathrm{N}_{2}$ counterflow. The resulting suspension was heated under $\mathrm{N}_{2}$ at $200{ }^{\circ} \mathrm{C}$ for 3 hours. The reaction mixture was then cooled to $100{ }^{\circ} \mathrm{C}$ and $150 \mathrm{~mL}$ of $\mathrm{N}_{2}$-sparged glacial acetic acid was slowly added in portions via cannula needle. After cooling to room temperature, the resulting viscous yellow-green solution solidified. Although the product oxidizes slowly in air to the corresponding disulfide, ${ }^{13}$ subsequent workup steps could be performed in air without significantly impacting the purity of the final product. In portions, $500 \mathrm{~mL}$ of diethyl ether and $700 \mathrm{~mL}$ of water were added to the reaction mixture. The aqueous and organic layers were separated, and the organic layer was washed twice with water. The organic layer was dried over sodium sulfate, filtered, and the solvent was removed via rotary evaporation. The resulting solution was transferred to a Schlenk flask equipped 
with a Teflon valve, and the solution was stirred under dynamic vacuum at $40{ }^{\circ} \mathrm{C}$ for 1 hour to remove excess acetic acid, affording crude 3 as a yellow-brown oil. This material was used in the next step without further purification.

${ }^{1} \mathrm{H} \mathrm{NMR}\left(\mathrm{CDCl}_{3}, 400 \mathrm{MHz}\right): 6.94(\mathrm{~d}, J=2.1 \mathrm{~Hz}, 1 \mathrm{H}), 6.73(\mathrm{~d}, J=2.1 \mathrm{~Hz}, 1 \mathrm{H}), 3.9($ broad s, $3 \mathrm{H}), 1.53(\mathrm{~s}$, 9H), $1.28(\mathrm{~s}, 9 \mathrm{H}) \mathrm{ppm}$.<smiles>CC(C)(C)c1cc(Br)c2c(c1)NC(C1Nc3cc(Br)cc(Br)c3S1)S2</smiles>

The crude 3 from above was dissolved in $125 \mathrm{~mL}$ of degassed methanol. The flask was heated to $40{ }^{\circ} \mathrm{C}$ under $\mathrm{N}_{2}$ and $2.5 \mathrm{~mL}(21.8 \mathrm{mmol}, 0.57$ equiv based on 2) of $40 \%$ aqueous glyoxal was added dropwise, resulting in the precipitation of a white solid. The Teflon valve was closed and the suspension was stirred for 1 hour at $40^{\circ} \mathrm{C}$. The reaction mixture was then cooled to room temperature and filtered in a glovebox. The resulting white solid was washed with $100 \mathrm{~mL}$ of hexanes in portions and dried under vacuum to give 4. This compound was isolated as a mixture (ca. $1.4: 1)$ of diastereomers. Yield: $5.31 \mathrm{~g}(56 \%$ yield $)$.

${ }^{1} \mathrm{H} \mathrm{NMR}\left(\mathrm{CDCl}_{3}, 400 \mathrm{MHz}\right): 6.90(\mathrm{~d}, J=1.8 \mathrm{~Hz}, 2 \mathrm{H}$ isomer A), $6.85(\mathrm{~d}, J=1.8 \mathrm{~Hz}, 2 \mathrm{H}$ isomer $\mathrm{B}), 6.67(2$ overlapping doublets, $2 \mathrm{H}$ isomer $\mathrm{A}+2 \mathrm{H}$ isomer $\mathrm{B}), 4.95(\mathrm{~m}, 2 \mathrm{H}$ isomer $\mathrm{A}+2 \mathrm{H}$ isomer $\mathrm{B}), 4.70(\mathrm{~s}, 2 \mathrm{H}$ isomer $\mathrm{B}$ ), $4.67(\mathrm{~s}, 2 \mathrm{H}$, isomer $\mathrm{A}$ ), 1.39 (2 overlapping s, $18 \mathrm{H}$ isomer $\mathrm{A}+18 \mathrm{H}$ isomer $\mathrm{B}$ ), 1.27 (2 overlapping $\mathrm{s}, 18 \mathrm{H}$ isomer $\mathrm{A}+18 \mathrm{H}$ isomer $\mathrm{B}) \mathrm{ppm}$.

Note on the synthesis of $\mathbf{5 a}$ and $\mathbf{5 b}$. The syntheses of $\mathbf{5 a}$ and $\mathbf{5 b}$ do not scale up well, which we hypothesize is due to inefficient cooling of the reaction mixture in large reaction vessels. In order to generate $\mathbf{5 a}$ and $\mathbf{5 b}$ on gram scale, multiple small-scale $(500 \mathrm{mg})$ reactions were performed in parallel and combined for workup. For these reactions, KHMDS was used as received from commercial suppliers.

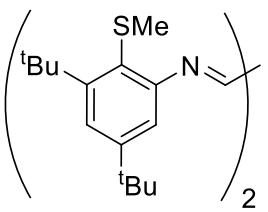

Synthesis of 5a. In an $\mathrm{N}_{2}$-filled glovebox, $500 \mathrm{mg}(1.01 \mathrm{mmol}) 4$ was dissolved in 15 $\mathrm{mL}$ of THF in each of 4 different $20 \mathrm{~mL}$ scintillation vials. The vials were cooled to -78 ${ }^{\circ} \mathrm{C}$ in a dry ice / acetone-cooled cold well and a cold solution of $408 \mathrm{mg}(2.05 \mathrm{mmol}, 2$ equiv) of KHMDS in $3 \mathrm{~mL}$ of THF was added to each vial, resulting in formation of a deep purple solution. A $150 \mu \mathrm{L}$ portion of methyl iodide ( $2.4 \mathrm{mmol}, 2.4$ equiv) was then added to each vial, causing a precipitate to form and the color to change to brown. After 30 minutes, the cooling bath was removed and the reactions were left to warm to room temperature overnight. Subsequent workup steps were performed in air. The contents of the vials were combined, the solvent was removed via rotary evaporation, and the resulting material was taken up in dichloromethane and filtered. The solvent was removed from the filtrate and the resulting yellow solid was dissolved in hot pentane and placed in $\mathrm{a}-25^{\circ} \mathrm{C}$ freezer overnight, resulting in the formation of yellow crystals. The crystals were collected and washed with cold pentane. A second crop was collected by concentrating the filtrate to $10 \mathrm{~mL}$ and placing this solution in a freezer. The combined crystals were dried under vacuum, yielding 1.91 $\mathrm{g}(90 \%$ yield $)$ of $5 \mathrm{a}$ as a yellow solid.

${ }^{1} \mathrm{H}$ NMR $\left(\mathrm{CD}_{2} \mathrm{Cl}_{2}, 400 \mathrm{MHz}\right): 8.37(\mathrm{~s}, 2 \mathrm{H}), 7.42(\mathrm{~s}, 2 \mathrm{H}), 6.91(\mathrm{~s}, 2 \mathrm{H}), 2.24(\mathrm{~s}, 6 \mathrm{H}), 1.59(\mathrm{~s}, 18 \mathrm{H}), 1.34(\mathrm{~s}$, 18H) ppm.

${ }^{13} \mathrm{C}\left\{{ }^{1} \mathrm{H}\right\}$ NMR $\left(\mathrm{CD}_{2} \mathrm{Cl}_{2}, 150 \mathrm{MHz}\right): 160.7,156.4,153.7,152.5,127.1,123.1,114.6,38.0,35.6,31.6,31.5$, $20.5 \mathrm{ppm}$.

HR-MS: $\left[\mathrm{M}+\mathrm{H}^{+}\right]$Expected 525.3332; Found: 525.3320.

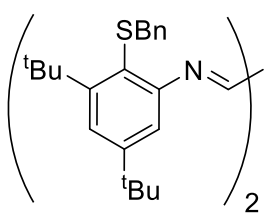

Synthesis of $\mathbf{5 b}$. In an $\mathrm{N}_{2}$-filled glovebox, $500 \mathrm{mg}(1.01 \mathrm{mmol}) \mathbf{4}$ was dissolved in 15 $\mathrm{mL}$ of THF in each of 4 different $20 \mathrm{~mL}$ scintillation vials. The vials were cooled to -78 ${ }^{\circ} \mathrm{C}$ in a dry ice / acetone-cooled cold well and a cold solution of $412 \mathrm{mg}(2.07 \mathrm{mmol})$ of KHMDS in $3 \mathrm{~mL}$ of THF was added to each vial, resulting in formation of a deep purple solution. A $0.30 \mathrm{~mL}$ portion of benzyl bromide $(2.5 \mathrm{mmol}, 2.5$ equiv) was then added to each vial, causing a precipitate to form and the color to change to brown. After 1 hour, the mixtures were removed from the cold well and stirred at room temperature overnight. Subsequent 
workup steps were performed in air. The contents of the vials were combined, the solvent was removed via rotary evaporation, and the resulting material was taken up in dichloromethane and filtered. The solvent was removed from the filtrate and the resulting yellow solid was triturated with pentane and dried under vacuum, yielding $1.97 \mathrm{~g}$ ( $72 \%$ yield $)$ of $\mathbf{5 b}$.

${ }^{1} \mathrm{H} \mathrm{NMR}\left(\mathrm{CD}_{2} \mathrm{Cl}_{2}, 400 \mathrm{MHz}\right): 8.50(\mathrm{~s}, 2 \mathrm{H}), 7.45(\mathrm{~d}, J=2.0 \mathrm{~Hz}, 2 \mathrm{H}), 7.22(\mathrm{~m}, 10 \mathrm{H}), 6.97(\mathrm{~d}, J=2.0 \mathrm{~Hz}, 2 \mathrm{H})$, $3.95(\mathrm{~s}, 4 \mathrm{H}), 1.56(\mathrm{~s}, 18 \mathrm{H}), 1.38(\mathrm{~s}, 18 \mathrm{H}) \mathrm{ppm}$.

${ }^{13} \mathrm{C}\left\{{ }^{1} \mathrm{H}\right\}$ NMR $\left(\mathrm{CD}_{2} \mathrm{Cl}_{2}, 150 \mathrm{MHz}\right): 160.7,156.4,154.0,152.8,138.3,129.6,128.9,127.6,125.8,123.3$, 114.5, 41.8, 38.0, 35.6, $31.6 \mathrm{ppm}$.

HR-MS: [M+H+ ${ }^{+}$]: Expected for $\mathrm{C}_{44} \mathrm{H}_{57} \mathrm{~N}_{2} \mathrm{~S}_{2}$ : 677.3958; Found: 677.3941 . [M+Na+]: Expected for $\mathrm{C}_{44} \mathrm{H}_{56} \mathrm{~N}_{2} \mathrm{~S}_{2}$ : 699.3777 Found: 699.3760.

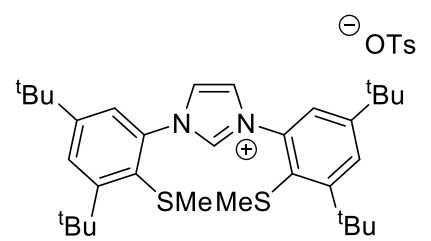

Synthesis of 6a. In a dry Schlenk flask under $\mathrm{N}_{2}, 2.11 \mathrm{~g}(4.02 \mathrm{mmol})$ of $\mathbf{5 a}$ was dissolved in $250 \mathrm{~mL}$ of dry, degassed toluene and cooled to $0{ }^{\circ} \mathrm{C}$ in an ice bath. A suspension of paraformaldehyde and $\mathrm{HCl}$ in dioxane was made by sonicating $230 \mathrm{mg}$ of paraformaldehyde in $2 \mathrm{~mL}$ of $4 \mathrm{M} \mathrm{HCl}$ in dioxane until the paraformaldehyde beads had broken apart (roughly 30 minutes). A $1.2 \mathrm{~mL}$ portion of this suspension (containing approximately $4.6 \mathrm{mmol}$ of paraformaldehyde and $4.8 \mathrm{mmol}$ of $\mathrm{HCl}$ ) was added to the flask. The solution changed color from yellow to red. Subsequent workup steps were performed in air. After 90 minutes, the solvent was removed under vacuum. The residue in the flask was suspended in pentane and filtered through a fritted glass filter funnel. The pentane-insoluble material was dissolved in $\mathrm{CH}_{2} \mathrm{Cl}_{2}$ and filtered. The solvent was removed from the filtrate via rotary evaporation giving $1.19 \mathrm{~g}$ of a brown solid.

This material was dissolved in $75 \mathrm{~mL}$ of dichloromethane and a solution of $2.42 \mathrm{~g}$ (12.7 mmol, 6.1 equiv) $p$ toluenesulfonic acid monohydrate in $75 \mathrm{~mL}$ of deionized water was added. The resulting biphasic mixture was stirred for 1.5 hours. The aqueous and organic layers were separated, and the organic layer was washed 3 times with water. The organic layer was dried over sodium sulfate, filtered, and the solvent was removed by rotary evaporation. The resulting residue was redissolved in $15 \mathrm{~mL}$ of dichloromethane and $150 \mathrm{~mL}$ of diethyl ether was added, resulting in precipitation of a white solid. The suspension was placed in a $-25^{\circ} \mathrm{C}$ freezer for 2 hours, and the solid was then collected by filtration, washed with diethyl ether, and dried under vacuum, yielding $1.05 \mathrm{~g}$ of the product. This material contained residual diethyl ether ( 0.3 equiv) based on ${ }^{1} \mathrm{H}$ NMR spectroscopy. The corrected yield is $1.00 \mathrm{~g} \mathrm{(35 \%} \mathrm{yield)} \mathrm{of} 6 \mathrm{a}$.

${ }^{1} \mathrm{H} \mathrm{NMR}\left(\mathrm{CD}_{2} \mathrm{Cl}_{2}, 600 \mathrm{MHz}\right): 9.44(\mathrm{~s}, 1 \mathrm{H}), 7.94(\mathrm{~s}, 2 \mathrm{H}), 7.76(\mathrm{~s}, 2 \mathrm{H}), 7.66(\mathrm{~s}, 2 \mathrm{H}), 7.43$ (d, J = $\left.7.9 \mathrm{~Hz}, 2 \mathrm{H}\right)$, $7.00(\mathrm{~d}, J=7.9 \mathrm{~Hz}, 2 \mathrm{H}), 2.29(\mathrm{~s}, 3 \mathrm{H}), 2.08(\mathrm{~s}, 6 \mathrm{H}), 1.61(\mathrm{~s}, 18 \mathrm{H}), 1.35(\mathrm{~s}, 18 \mathrm{H}) \mathrm{ppm}$.

${ }^{13} \mathrm{C}\left\{{ }^{1} \mathrm{H}\right\}$ NMR $\left(\mathrm{CD}_{2} \mathrm{Cl}_{2}, 150 \mathrm{MHz}\right): 156.1,154.5,145.7,140.4,139.6,138.9,128.8,128.7,127.6,126.3$, $125.3,124.1,38.6,35.8,31.5,31.3,21.6,21.5 \mathrm{ppm}$.

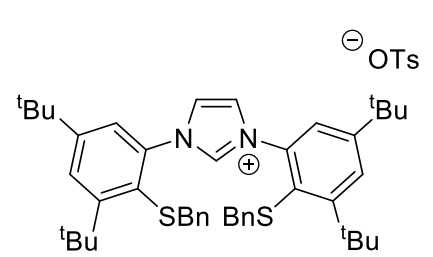

HR-MS: Calculated for $\mathrm{C}_{33} \mathrm{H}_{49} \mathrm{~N}_{2} \mathrm{~S}_{2}: 537.3337$ Found: 537.3312.

Synthesis of $\mathbf{6 b}$. In a dry Schlenk flask under $\mathrm{N}_{2}, 3.18 \mathrm{~g}(4.70 \mathrm{mmol})$ of $\mathbf{5 b}$ was dissolved in $450 \mathrm{~mL}$ of dry, degassed toluene. The flask was cooled to 0 ${ }^{\circ} \mathrm{C}$ in an ice bath. A suspension of paraformaldehyde was prepared by combining $271 \mathrm{mg}$ of paraformaldehyde with $2.3 \mathrm{~mL}$ of $4 \mathrm{M} \mathrm{HCl}$ in dioxane under $\mathrm{N}_{2}$ in a Schlenk flask equipped with a Teflon pin and sonicating until the paraformaldehyde pellets had broken apart (approximately 30 minutes). A $1.5 \mathrm{~mL}$ portion of this suspension (containing approximately $5.9 \mathrm{mmol}$ paraformaldehyde and $6.0 \mathrm{mmol} \mathrm{HCl}$ ) was added to the Schlenk flask, resulting in a color change from yellow to red. The reaction mixture was stirred and allowed to warm to room temperature over 4 hours. Subsequent workup steps were performed in air. The solvent was removed via rotary evaporation, affording a red oil. This material was chromatographed on silica using 9:1 dichloromethane:methanol as the eluent (product $R_{f}=0.5$ ). All product-containing fractions were combined and the solvent was removed via rotary evaporation, giving $1.52 \mathrm{~g}$ of a brown foam. The product co-elutes with an unknown red impurity which is removed in the next step. 
The brown foam was dissolved in $80 \mathrm{~mL}$ of dichloromethane, and a solution of $3.97 \mathrm{~g}(20.9 \mathrm{mmol}) p$ toluenesulfonic acid monohydrate in $80 \mathrm{~mL}$ of deionized water was added. The resulting biphasic mixture was stirred at room temperature for 2 hours. The organic layer was collected, washed 3 times with water, and dried over sodium sulfate. The mixture was filtered, and the solvent was removed via rotary evaporation, giving a brown foam. The foam was dissolved in $5 \mathrm{~mL}$ of THF and $150 \mathrm{~mL}$ hexanes was added, resulting in precipitation of a white solid. The solid was filtered off and washed with hexanes until the washes were colorless (approximately $100 \mathrm{~mL}$ ). This white solid was dried under vacuum, affording $1.52 \mathrm{~g}$ of the title compound. This material contains residual hexanes ( 0.4 equiv) based on ${ }^{1} \mathrm{H}$ NMR spectroscopy; the corrected yield is $1.46 \mathrm{~g}$ (36\% yield).

${ }^{1} \mathrm{H}$ NMR $\left(\mathrm{CD}_{2} \mathrm{Cl}_{2}, 600 \mathrm{MHz}\right): 8.57(\mathrm{~s}, 1 \mathrm{H}), 7.84(\mathrm{~s}, 2 \mathrm{H}), 7.82(\mathrm{~d}, J=1.9 \mathrm{~Hz}, 2 \mathrm{H}), 7.48(\mathrm{~d}, J=8.0 \mathrm{~Hz}, 2 \mathrm{H})$, $7.46(\mathrm{~d}, J=1.9 \mathrm{~Hz}, 2 \mathrm{H}), 7.13(\mathrm{~m}, 6 \mathrm{H}), 6.98(\mathrm{~d}, J=8.0 \mathrm{~Hz}, 2 \mathrm{H}), 6.88(\mathrm{~d}, J=7.7 \mathrm{~Hz}, 4 \mathrm{H}), 3.58(\mathrm{~s}, 4 \mathrm{H}), 2.27$ $(\mathrm{s}, 3 \mathrm{H}), 1.62(\mathrm{~s}, 18 \mathrm{H}), 1.38(\mathrm{~s}, 18 \mathrm{H}) \mathrm{ppm}$.

${ }^{13} \mathrm{C}\left\{{ }^{1} \mathrm{H}\right\}$ NMR $\left(\mathrm{CD}_{2} \mathrm{Cl}_{2}, 150 \mathrm{MHz}\right): 157.0,155.0,145.7,140.6,139.0,138.9,136.9,129.4,129.3,128.7$, $128.2,127.9,126.6,126.3,125.0,123.3,43.5,38.8,35.9,31.8,31.3,21.5 \mathrm{ppm}$.

HR-MS: Calculated for $\mathrm{C}_{45} \mathrm{H}_{57} \mathrm{~N}_{2} \mathrm{~S}_{2}: 689.3963$ Found: 689.3937.<smiles></smiles>

Synthesis of 7 . In an $\mathrm{N}_{2}$-filled glovebox, a solution of potassium naphthalenide was formed by stirring $208 \mathrm{mg}(5.33 \mathrm{mmol})$ freshly cut potassium with $868 \mathrm{mg}$ naphthalene $(6.77 \mathrm{mmol})$ in $30 \mathrm{~mL}$ THF until the

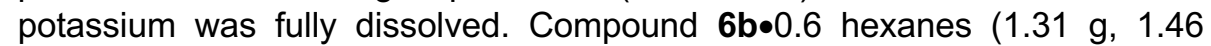
$\mathrm{mmol}$ ) was dissolved in $150 \mathrm{~mL}$ THF in a Schlenk flask equipped with a Teflon valve. The flask was cooled to $-70{ }^{\circ} \mathrm{C}$ in a dry ice / acetone cold well. The potassium naphthalenide was added via pipette and the flask was sealed. After 30 minutes, the flask was transferred out of the glovebox to a dry ice / acetone bath. The flask was placed under $\mathrm{N}_{2}$ and $15 \mathrm{~mL}$ of degassed anhydrous methanol was added. The flask was then sealed and warmed to room temperature. The solvent was removed under vacuum and the naphthalene was sublimed off by gently heating the flask with a heat gun under vacuum. The flask was transferred in to an $\mathrm{N}_{2}$-filled glovebox for workup. The residue in the flask was taken up in 30 $\mathrm{mL}$ of THF and filtered through Celite to remove salt byproducts. The solvent was removed from the filtrate under vacuum. The resulting material was triturated with pentane and dried under vacuum, giving $544 \mathrm{mg}$ of white solid. This material contains 0.5 equiv of THF based on ${ }^{1} \mathrm{H}$ NMR spectroscopy; the corrected yield is $510 \mathrm{mg}(64 \%$ yield $)$ of $\mathbf{6 b}$.

${ }^{1} \mathrm{H}$ NMR (THF-ds, $\left.600 \mathrm{MHz}\right): 9.35(\mathrm{~s}, 1 \mathrm{H}), 7.75(\mathrm{~s}, 2 \mathrm{H}), 7.32(\mathrm{~s}, 2 \mathrm{H}), 6.92(\mathrm{~s}, 2 \mathrm{H}), 1.71(\mathrm{~s}, 18 \mathrm{H}), 1.28(\mathrm{~s}$, 18H) $\mathrm{ppm}$.

${ }^{13} \mathrm{C}\left\{{ }^{1} \mathrm{H}\right\}$ NMR (THF-d $\left.8,150 \mathrm{MHz}\right): 152.4,152.2,139.6,139.1,138.8,124.2,123.2,119.7,39.1,34.9,32.0$, $30.2 \mathrm{ppm}$.

HR-MS: Calculated for $\mathrm{C}_{31} \mathrm{H}_{45} \mathrm{~N}_{2} \mathrm{~S}_{2}\left[\mathrm{M}+2 \mathrm{H}^{+}\right]: 509.3019$ Found: 509.3012 .<smiles></smiles>

Synthesis of $\mathbf{S}^{\mathrm{Me}} \mathrm{CS}^{\mathrm{Me}}$. A $150 \mathrm{mg}$ portion $(0.21 \mathrm{mmol})$ of 6 a was dissolved in $10 \mathrm{~mL}$ of THF and a solution of $42.3 \mathrm{mg}(0.21 \mathrm{mmol}) \mathrm{KHMDS}$ in $4 \mathrm{~mL}$ THF was added dropwise, resulting in formation of a white precipitate. After 1 hour, the volatile materials were removed under vacuum. The resulting white solid was taken up in $10 \mathrm{~mL}$ of diethyl ether and filtered through Celite. The solvent was removed from the filtrate and the resulting solid was taken up in $15 \mathrm{~mL}$ diethyl ether and filtered through Celite again. The filtrate was dried under vacuum giving $104.7 \mathrm{mg}\left(92 \%\right.$ yield) of $\mathbf{S}^{\mathrm{Me}} \mathbf{C S}^{\mathrm{Me}}$ as a white solid.

${ }^{1} \mathrm{H}$ NMR $\left(\mathrm{C}_{6} \mathrm{D}_{6}, 400 \mathrm{MHz}\right): 7.87(\mathrm{~d}, J=2.1 \mathrm{~Hz}, 2 \mathrm{H}), 7.69$ (d, J = 2.1 Hz, 2H), $7.33(\mathrm{~s}, 2 \mathrm{H}), 2.05(\mathrm{~s}, 6 \mathrm{H}), 1.72$ $(\mathrm{s}, 18 \mathrm{H}), 1.19(\mathrm{~s}, 18 \mathrm{H}) \mathrm{ppm}$.

${ }^{13} \mathrm{C}\left\{{ }^{1} \mathrm{H}\right\}$ NMR $\left(\mathrm{C}_{6} \mathrm{D}_{6}, 150 \mathrm{MHz}\right): 218.2,153.9,151.8,148.4,129.4,125.5,123.6,121.8,38.1,35.0,31.7$, 31.2, $20.2 \mathrm{ppm}$. 
NMR spectra of ligands and synthetic intermediates

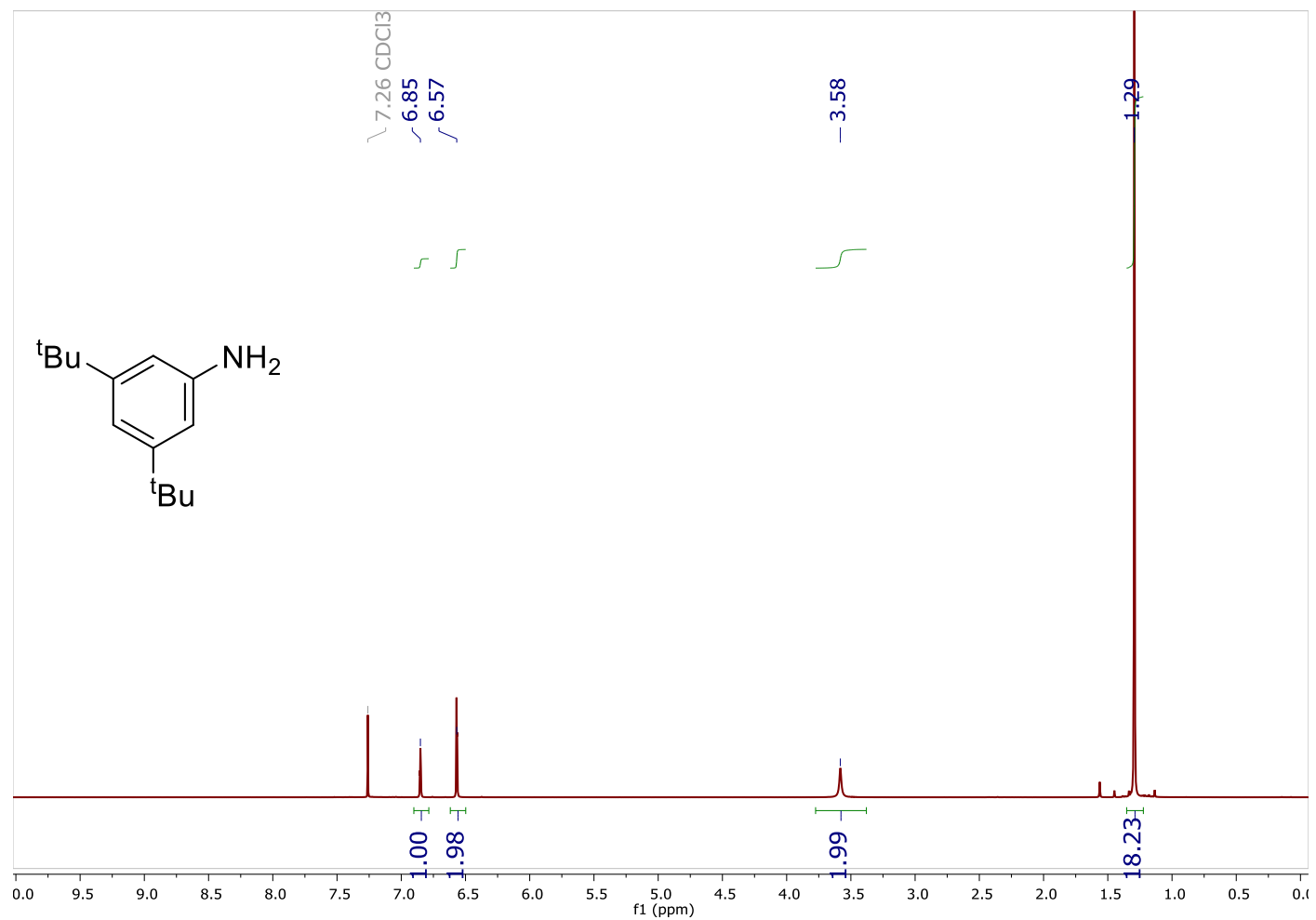

Figure S1. ${ }^{1} \mathrm{H}$ NMR spectrum of $1\left(\mathrm{CDCl}_{3}, 400 \mathrm{MHz}\right)$

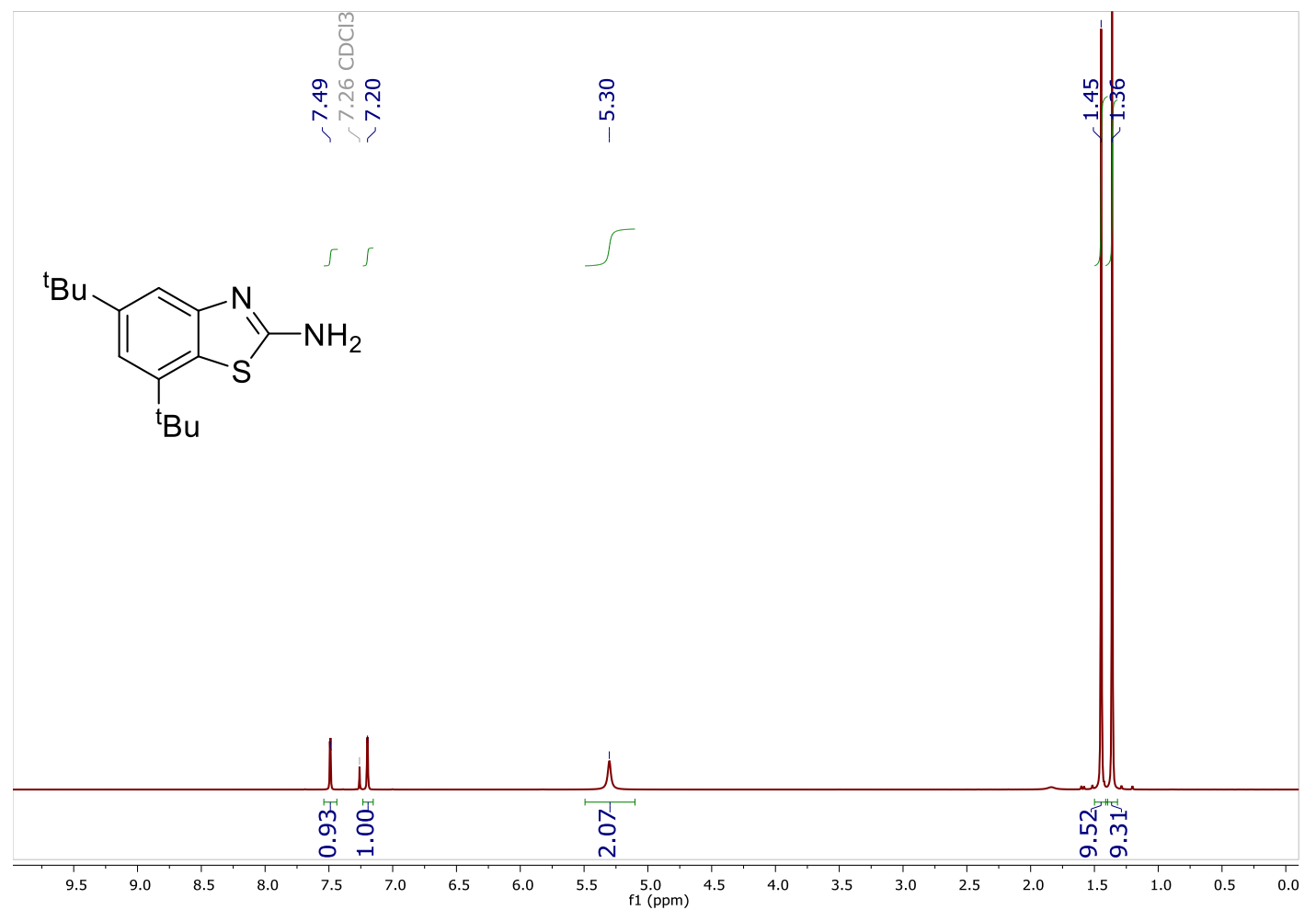

Figure S2. ${ }^{1} \mathrm{H}$ NMR spectrum of $2\left(\mathrm{CDCl}_{3}, 400 \mathrm{MHz}\right)$ 


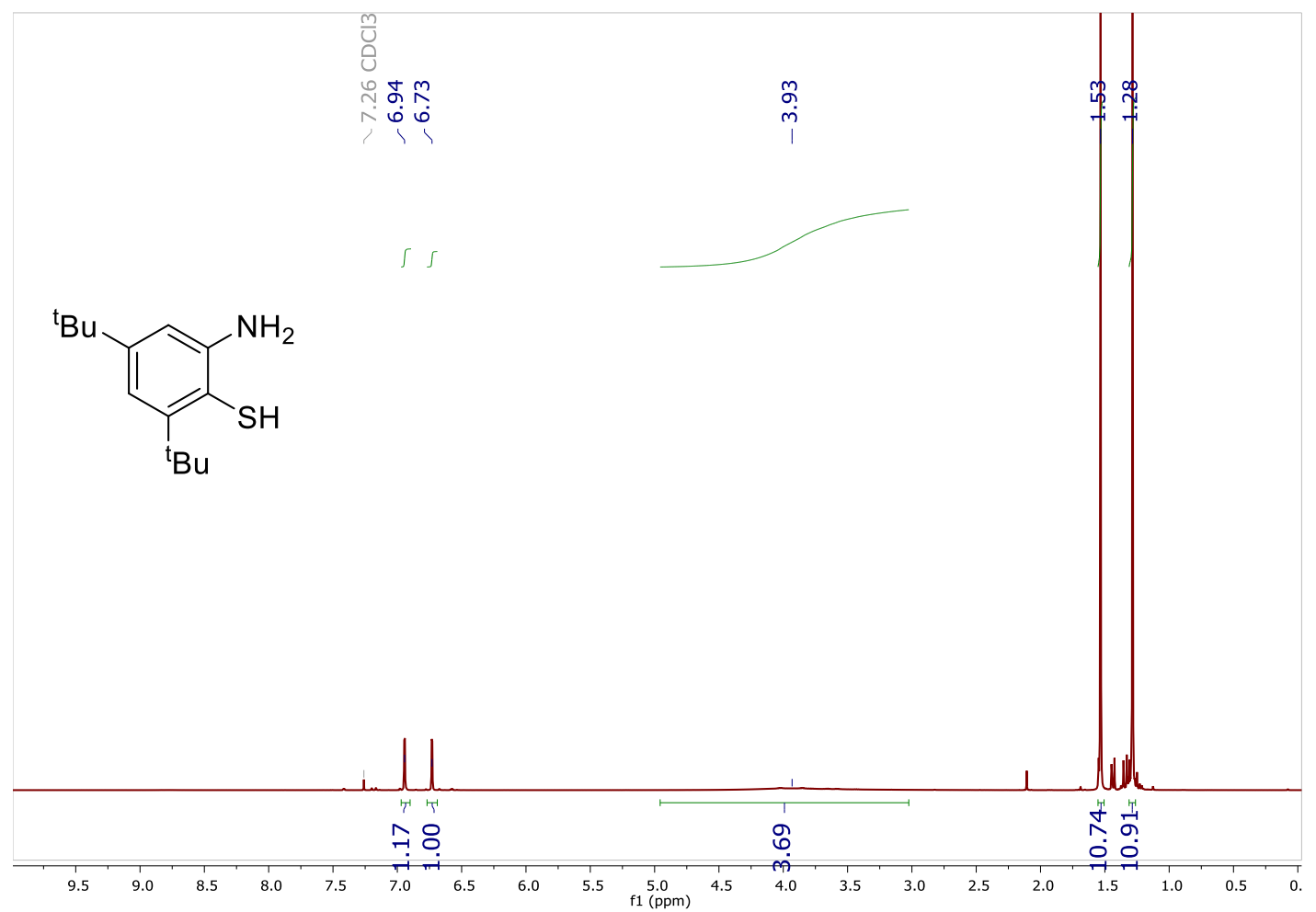

Figure S3. ${ }^{1} \mathrm{H}$ NMR spectrum of $3\left(\mathrm{CDCl}_{3}, 400 \mathrm{MHz}\right)$

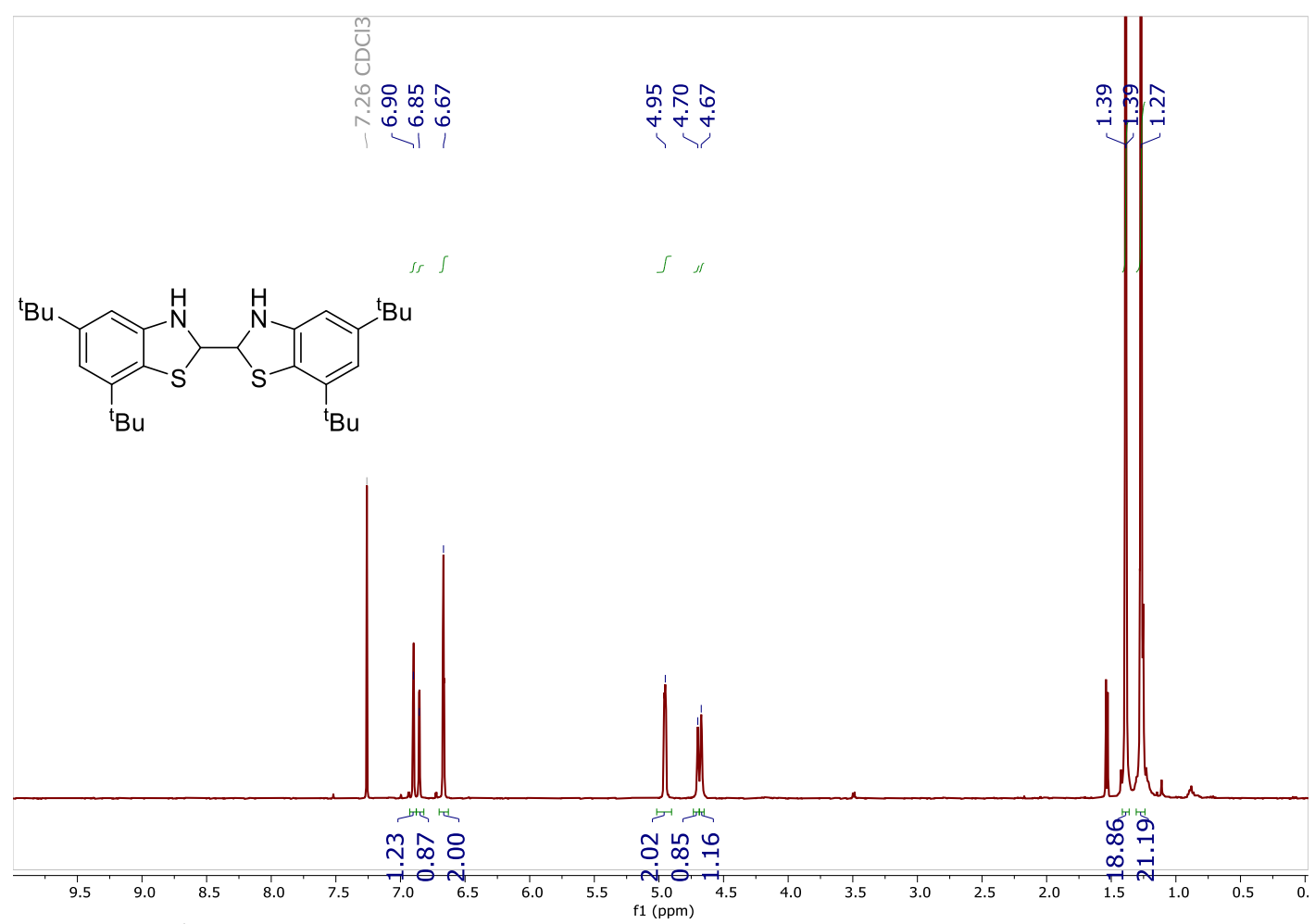

Figure S4. ${ }^{1} \mathrm{H}$ NMR spectrum of $4\left(\mathrm{CDCl}_{3}, 400 \mathrm{MHz}\right)$ 

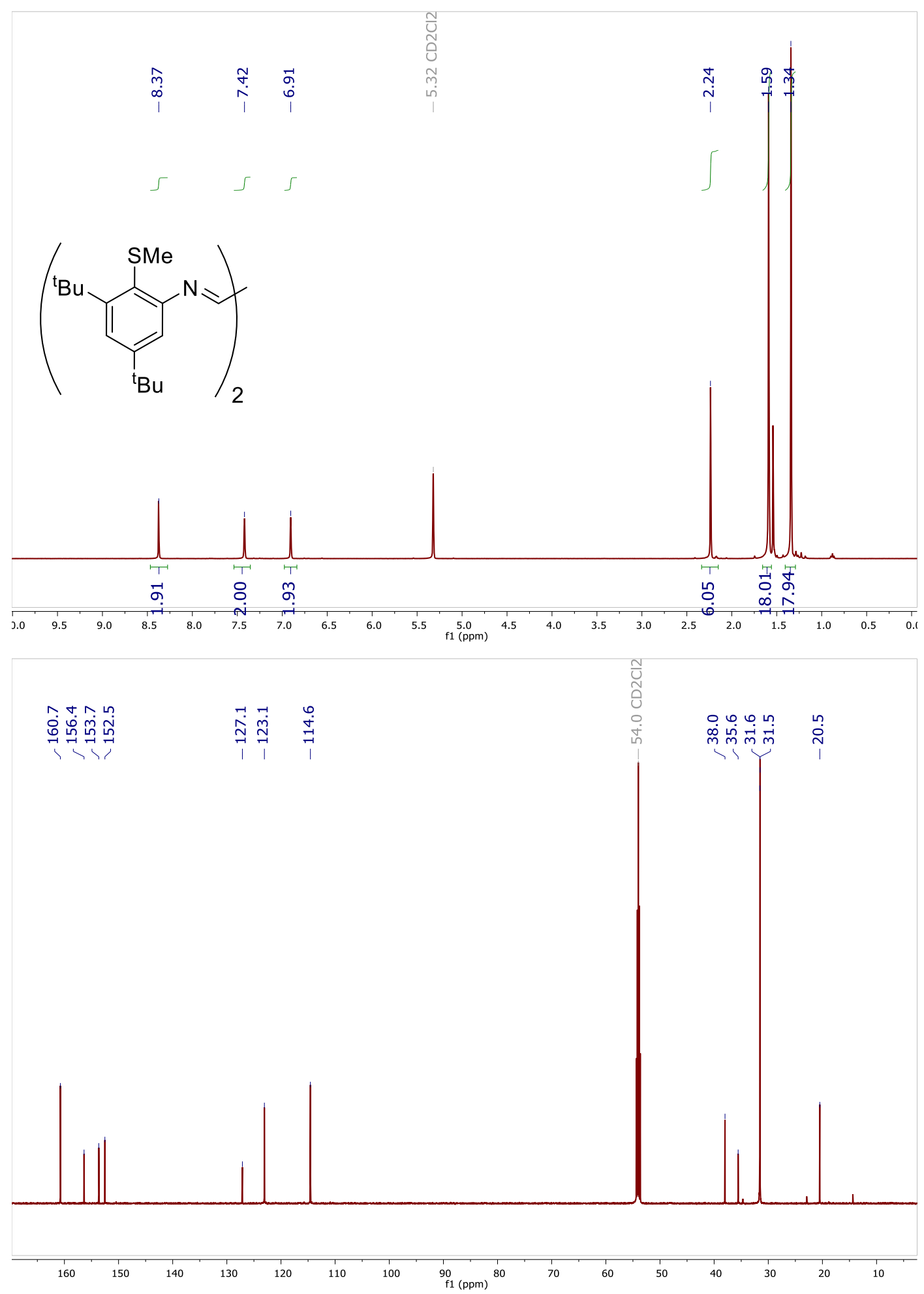

Figure S5. Top: ${ }^{1} \mathrm{H}$ NMR spectrum of $5 \mathrm{a}\left(\mathrm{CD}_{2} \mathrm{Cl}_{2}, 400 \mathrm{MHz}\right)$ Bottom: ${ }^{13} \mathrm{C}\left\{{ }^{1} \mathrm{H}\right\} \mathrm{NMR}$ spectrum of $5 \mathrm{a}\left(\mathrm{CD}_{2} \mathrm{Cl}_{2}\right.$, $150 \mathrm{MHz})$ 

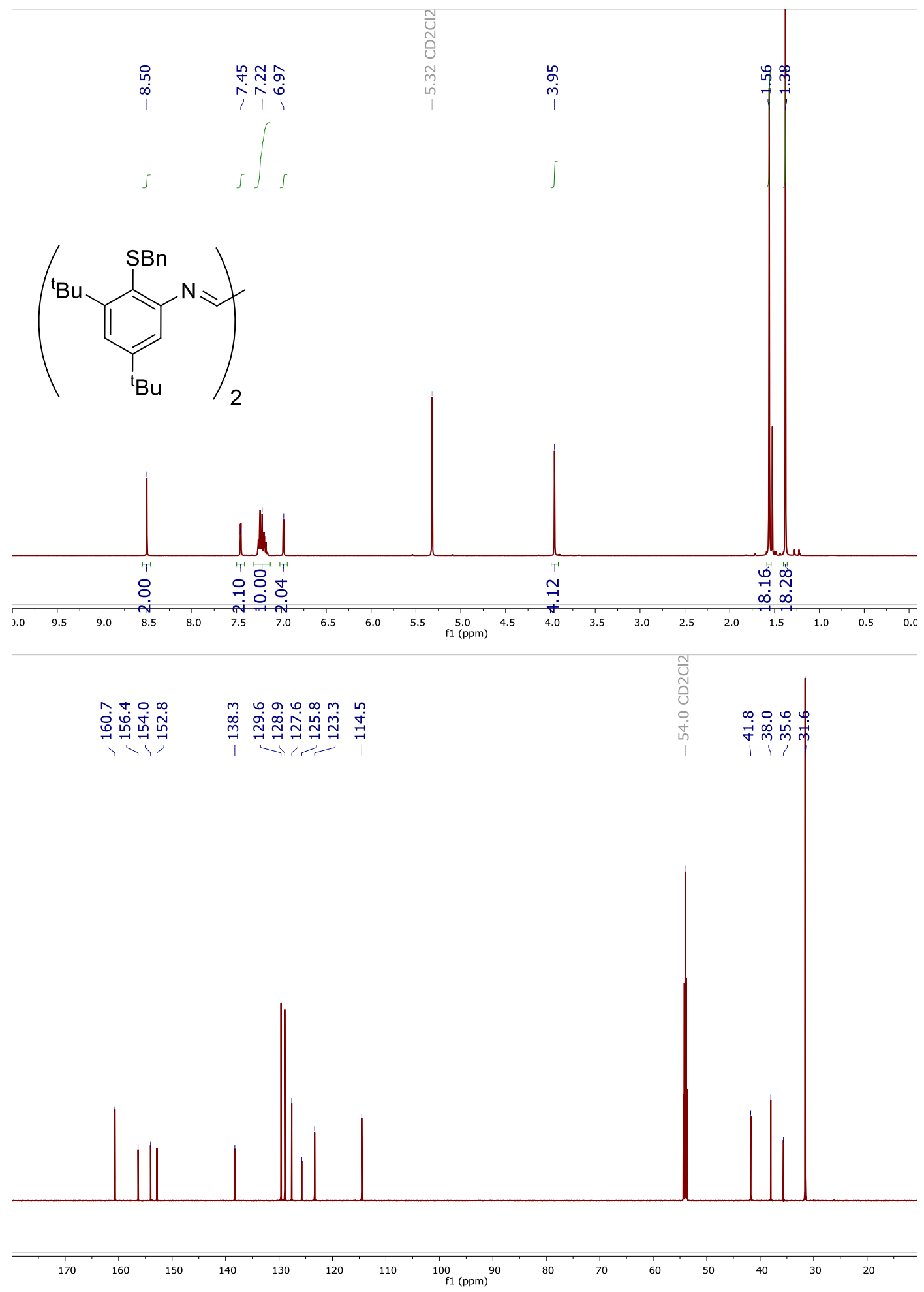

Figure S6. Top: ${ }^{1} \mathrm{H}$ NMR spectrum of $\mathbf{5 b}\left(\mathrm{CD}_{2} \mathrm{Cl}_{2}, 400 \mathrm{MHz}\right)$ Bottom: ${ }^{13} \mathrm{C}\left\{{ }^{1} \mathrm{H}\right\} \mathrm{NMR}$ spectrum of $\mathbf{5 b}\left(\mathrm{CD}_{2} \mathrm{Cl}_{2}\right.$, $150 \mathrm{MHz})$ 

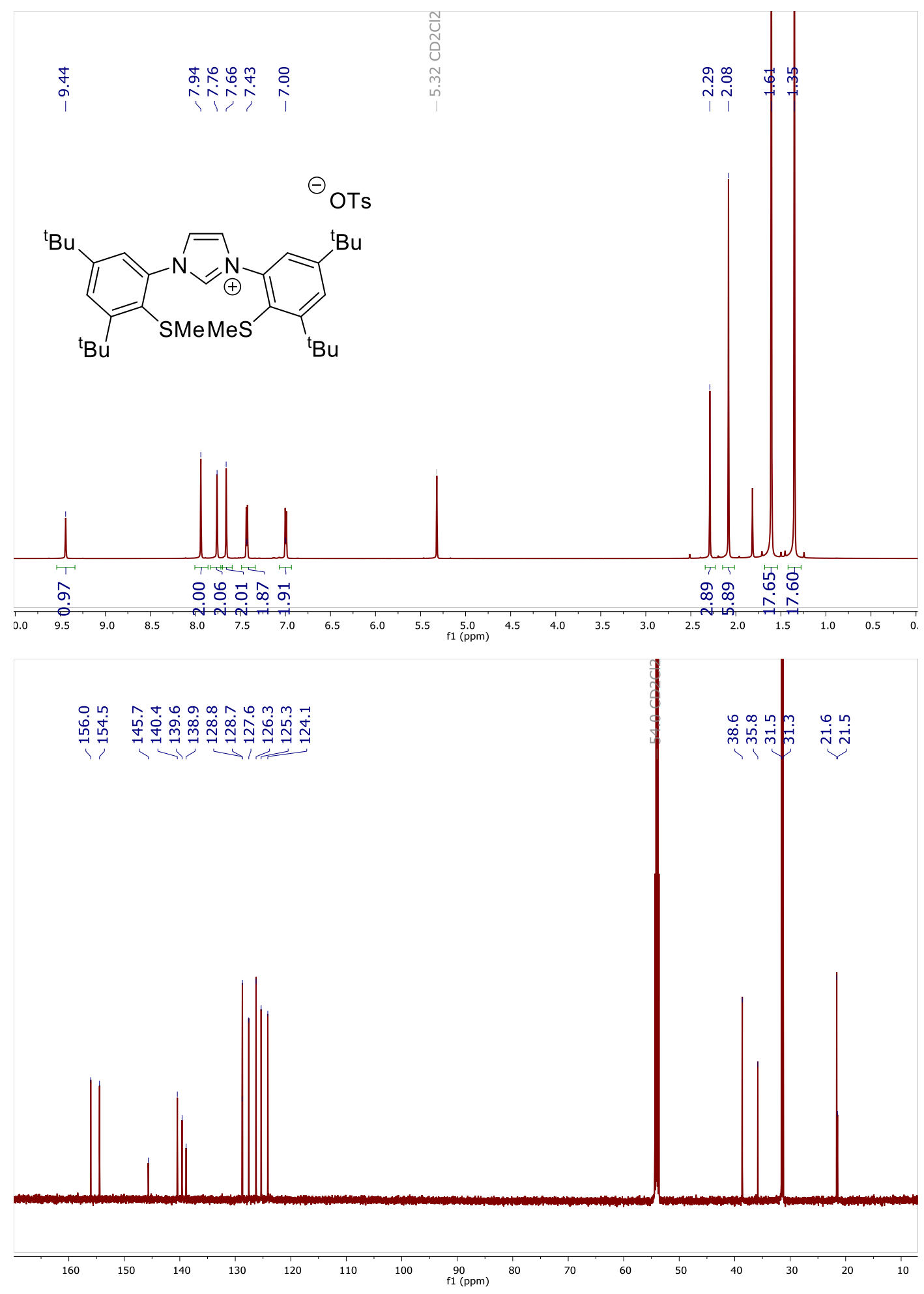

Figure S7. Top: ${ }^{1} \mathrm{H}$ NMR spectrum of $6 \mathbf{a}\left(\mathrm{CD}_{2} \mathrm{Cl}_{2}, 600 \mathrm{MHz}\right)$ Bottom: ${ }^{13} \mathrm{C}\left\{{ }^{1} \mathrm{H}\right\} \mathrm{NMR}$ spectrum of $6 \mathbf{a}\left(\mathrm{CD}_{2} \mathrm{Cl}_{2}\right.$, $150 \mathrm{MHz})$ 

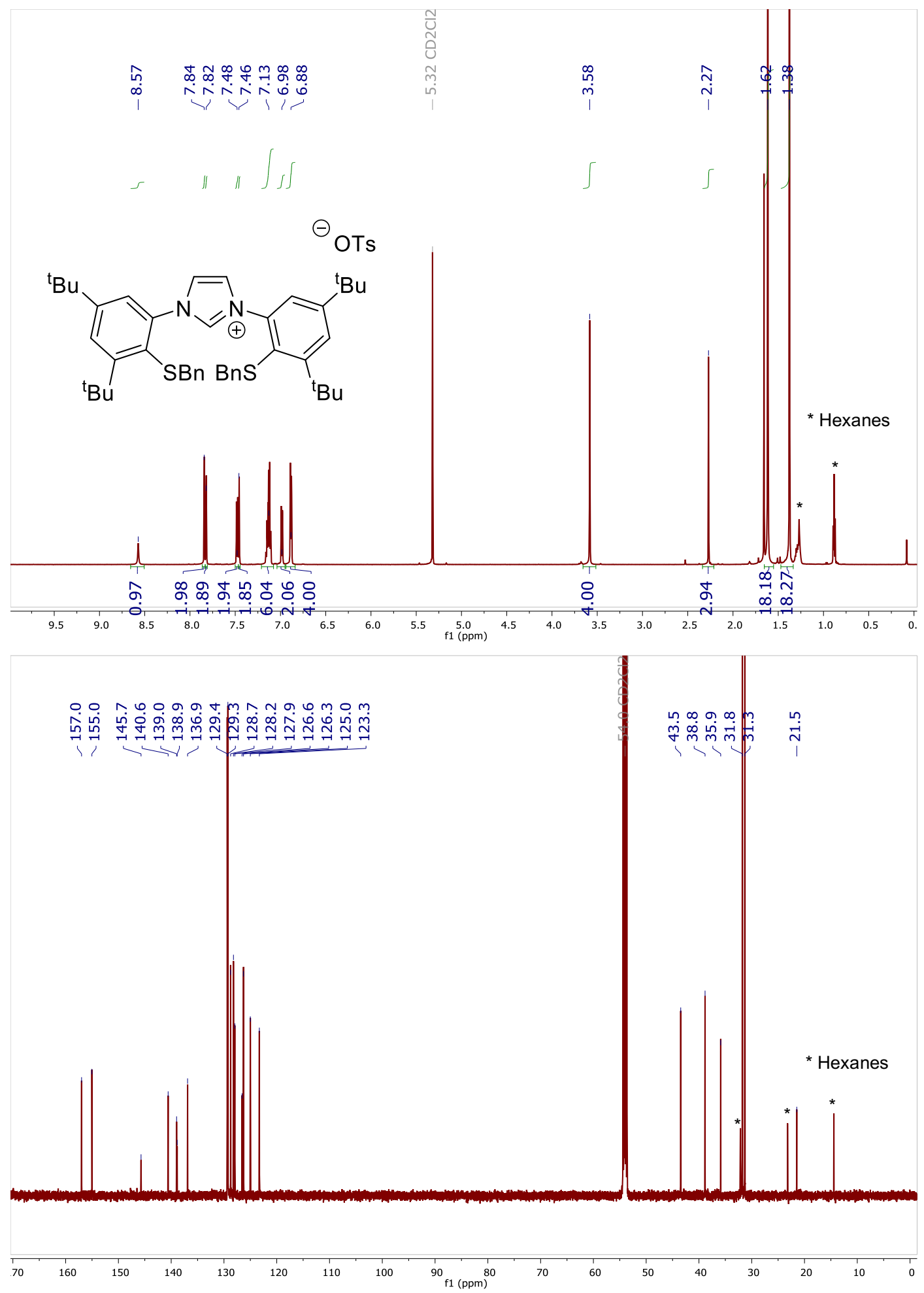

Figure S8. Top: ${ }^{1} \mathrm{H}$ NMR spectrum of $6 \mathbf{b}\left(\mathrm{CD}_{2} \mathrm{Cl}_{2}, 600 \mathrm{MHz}\right)$ Bottom: ${ }^{13} \mathrm{C}\left\{{ }^{1} \mathrm{H}\right\} \mathrm{NMR}$ spectrum of $\mathbf{6 b}\left(\mathrm{CD}_{2} \mathrm{Cl}_{2}\right.$, $150 \mathrm{MHz}$ ). This material contains residual hexanes (marked with an asterisk). 


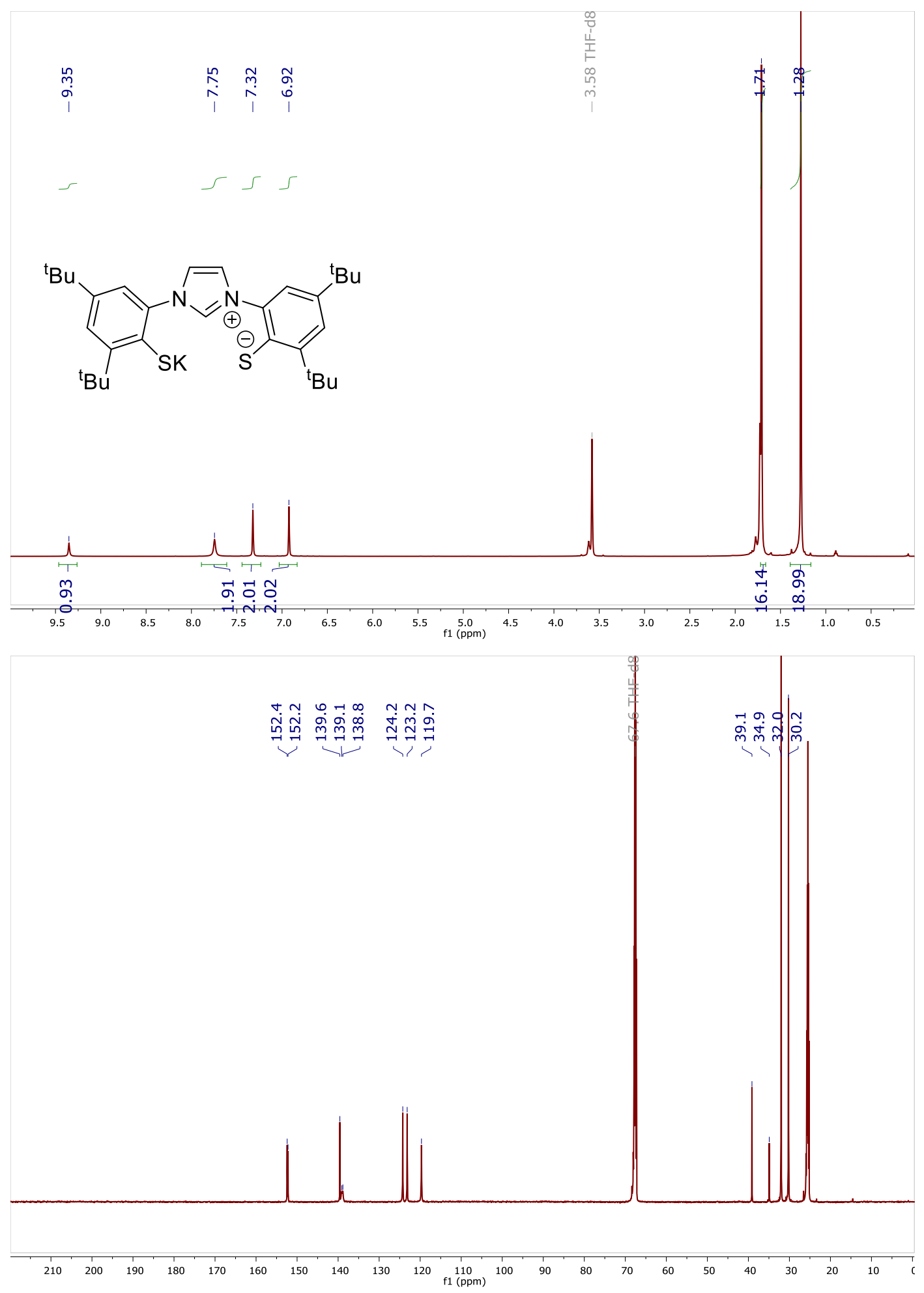

Figure S9. Top: ${ }^{1} \mathrm{H}$ NMR spectrum of $7\left(\mathrm{THF}-d_{8}, 600 \mathrm{MHz}\right)$ Bottom: ${ }^{13} \mathrm{C}\left\{{ }^{1} \mathrm{H}\right\}$ NMR spectrum of 7 (THF- $d_{8}$, $150 \mathrm{MHz})$ 

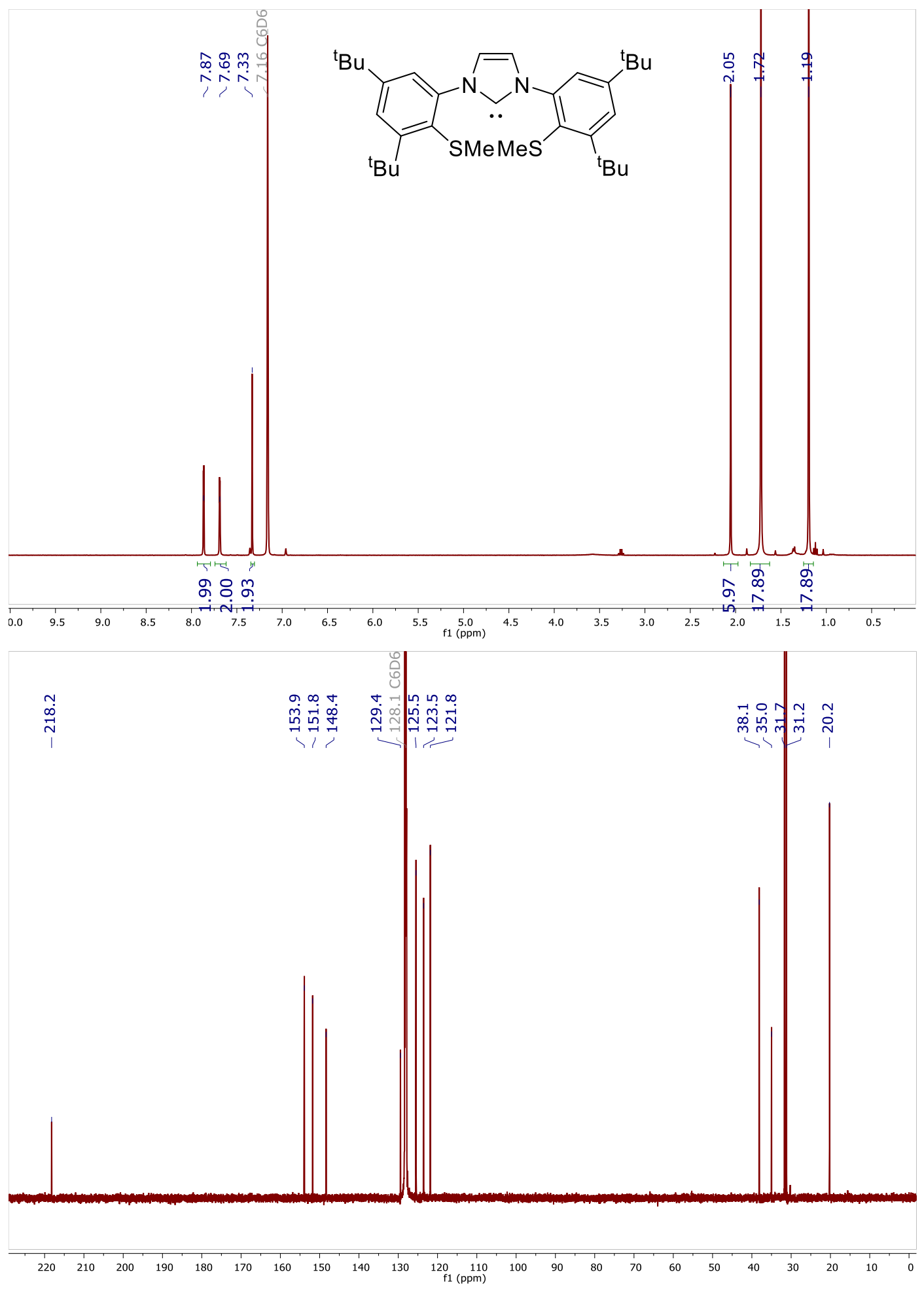

Figure S10. Top: ${ }^{1} \mathrm{H}$ NMR spectrum of $\mathbf{S}^{\mathrm{Me}} \mathbf{C S}^{\mathrm{Me}}\left(\mathrm{C}_{6} \mathrm{D}_{6}, 400 \mathrm{MHz}\right)$ Bottom: ${ }^{13} \mathrm{C}\left\{{ }^{1} \mathrm{H}\right\}$ NMR spectrum of $\mathbf{S}^{\mathrm{Me}} \mathbf{C S}^{\mathrm{Me}}\left(\mathrm{C}_{6} \mathrm{D}_{6}, 150 \mathrm{MHz}\right)$ 


\section{Supplemental experiments for ligand synthesis}

Acid-induced rearrangement during deprotection of $\mathbf{6 b}$. Deprotection of $\mathbf{6 b}$ was carried out as described above, except that the reaction mixture was quenched by addition of excess (13 equiv) $2 \mathrm{M} \mathrm{HCl}$ in diethyl ether. The solvent was removed under vacuum and the crude reaction mixture was taken up in dichloromethane and filtered. An initial aliquot of this solution was dried under vacuum, redissolved in $\mathrm{CD}_{2} \mathrm{Cl}_{2}$, and analyzed by ${ }^{1} \mathrm{H}$ NMR spectroscopy. A second aliquot was analyzed after 24 hours.
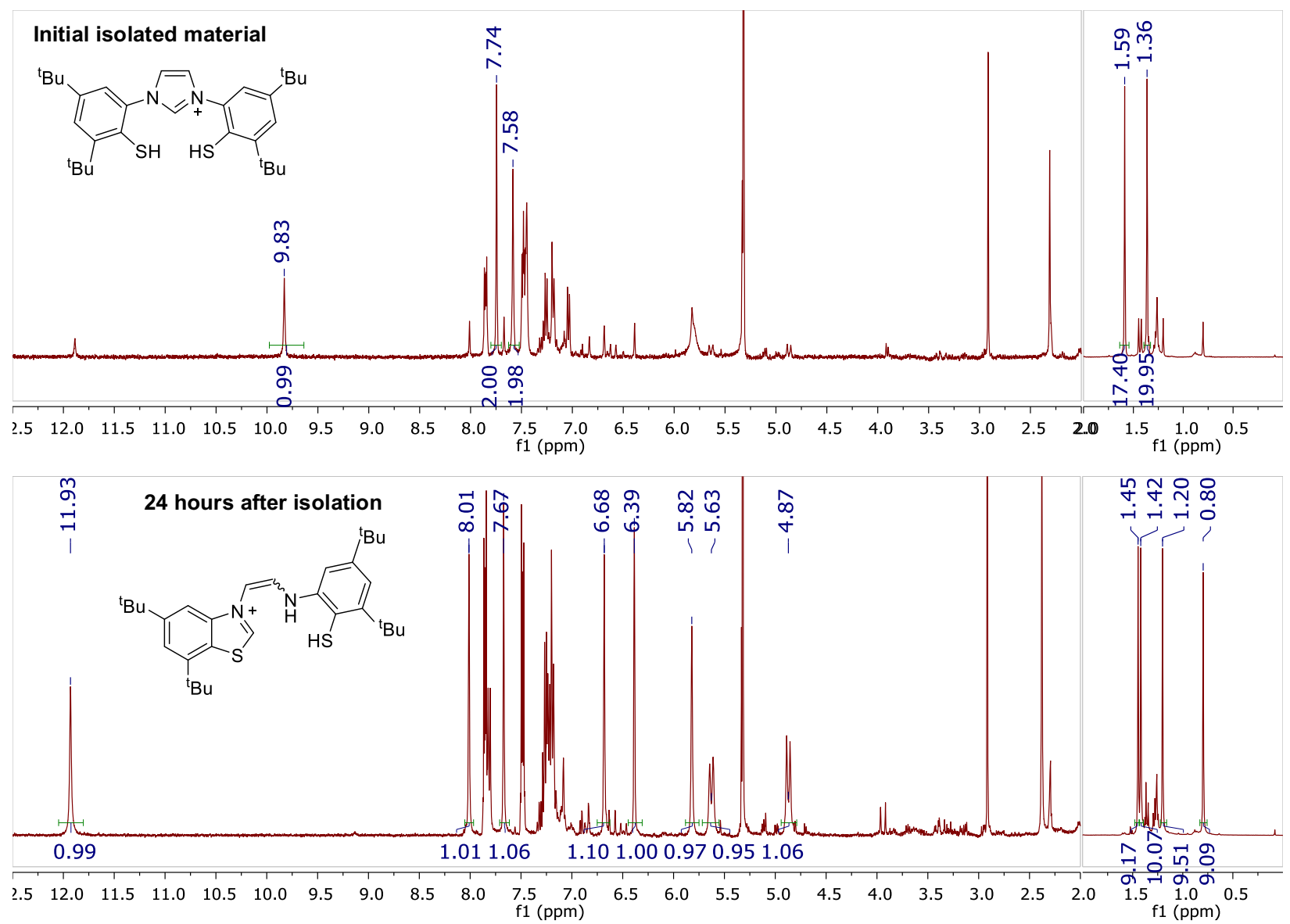

Figure S11. ${ }^{1} \mathrm{H} \mathrm{NMR}\left(\mathrm{CD}_{2} \mathrm{Cl}_{2}, 400 \mathrm{MHz}\right)$ of the crude reaction mixture from deprotection of $6 \mathbf{b}$ immediately after isolation (top) and after stirring in $\mathrm{CH}_{2} \mathrm{Cl}_{2}$ for 24 hours (bottom). The region from 0-2 ppm is shown at $\sim 10 x$ lower intensity than the rest of the spectrum. Resonances that can be assigned to the bis(thiol) imidazolium and benzothiazolium/aminothiol are labeled in the top and bottom spectra, respectively. Several resonances cannot be identified due to overlap with byproducts from the deprotection. We note that the coupling constant for the olefin protons $(J=13 \mathrm{~Hz})$ is between typical values for cis and trans alkenes and does not allow assignment of the stereochemistry of the rearranged species. 
Protonation of 7. In order to further confirm that acid, rather than a byproduct from the deprotection, causes decomposition of the bis(thiol) imidazolium salt, a THF solution of 7 was treated with 3.4 equiv of $\mathrm{HCl}$. After $5 \mathrm{~min}$, the volatile materials were removed under vacuum and the product was taken up in THF-d8 and filtered into a J. Young NMR tube. In this case, only a trace amount of the putative bis(thiol) imidazolium salt was observed $30 \mathrm{~min}$ after treatment with $\mathrm{HCl}$, and full conversion to the rearranged product was observed after $1 \mathrm{~h}$. The reason for the more rapid rearrangement in this reaction as compared to the experiment with the crude deprotection described above is not clear, but could be related to a change in ion pairing as a result of the additional salts present in the crude deprotection reaction. In analogous rearrangements with an $\mathrm{N}(\mathrm{NHC}) \mathrm{O}$ ligand, the counteranion has been proposed to play a role in rearrangement. ${ }^{14}$

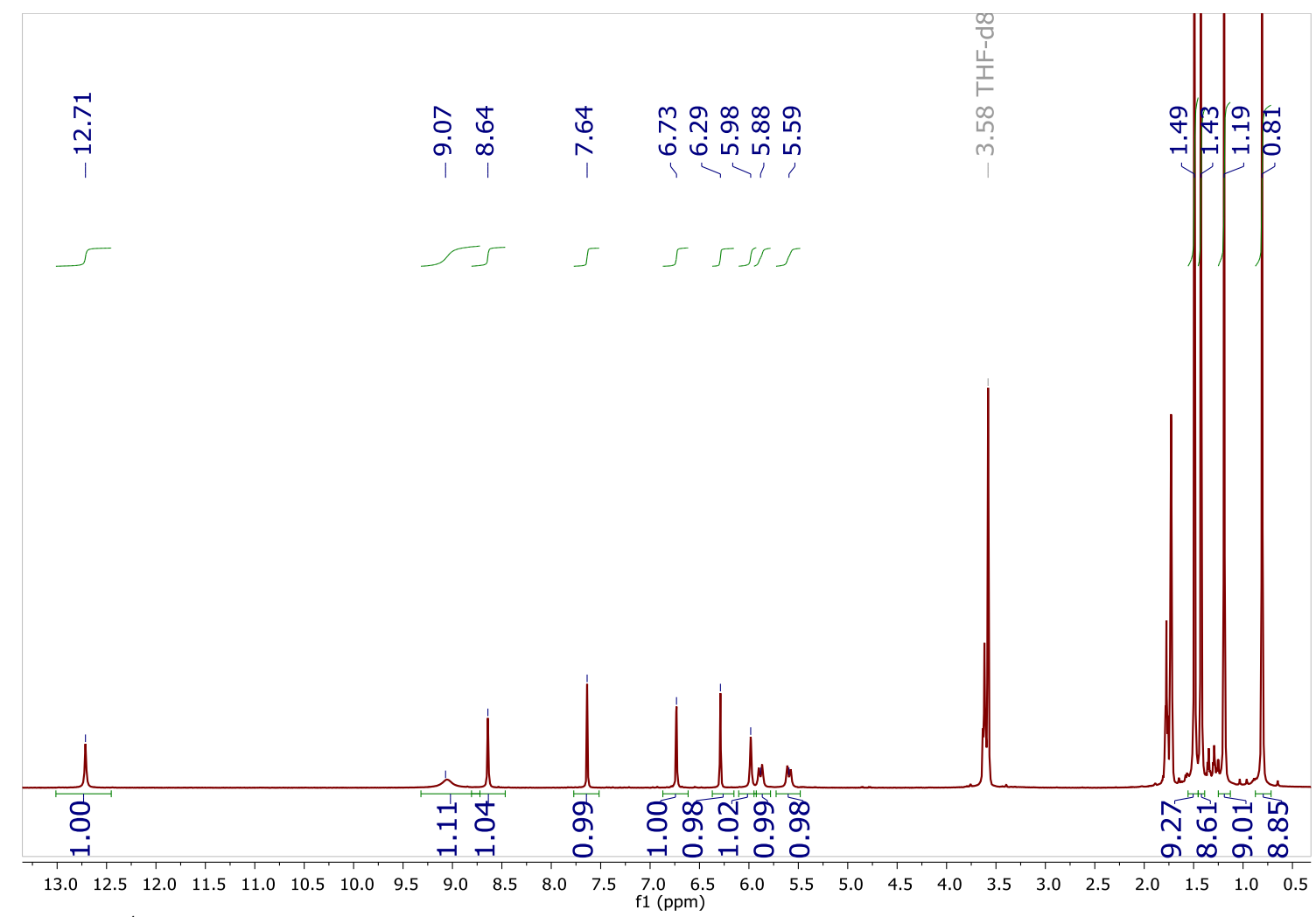

Figure S12. ${ }^{1} \mathrm{H}$ NMR spectrum (THF-d8, $400 \mathrm{MHz}$ ) of the final product from treatment of 7 with excess $\mathrm{HCl}$. 


\section{Deprotonation of 7}

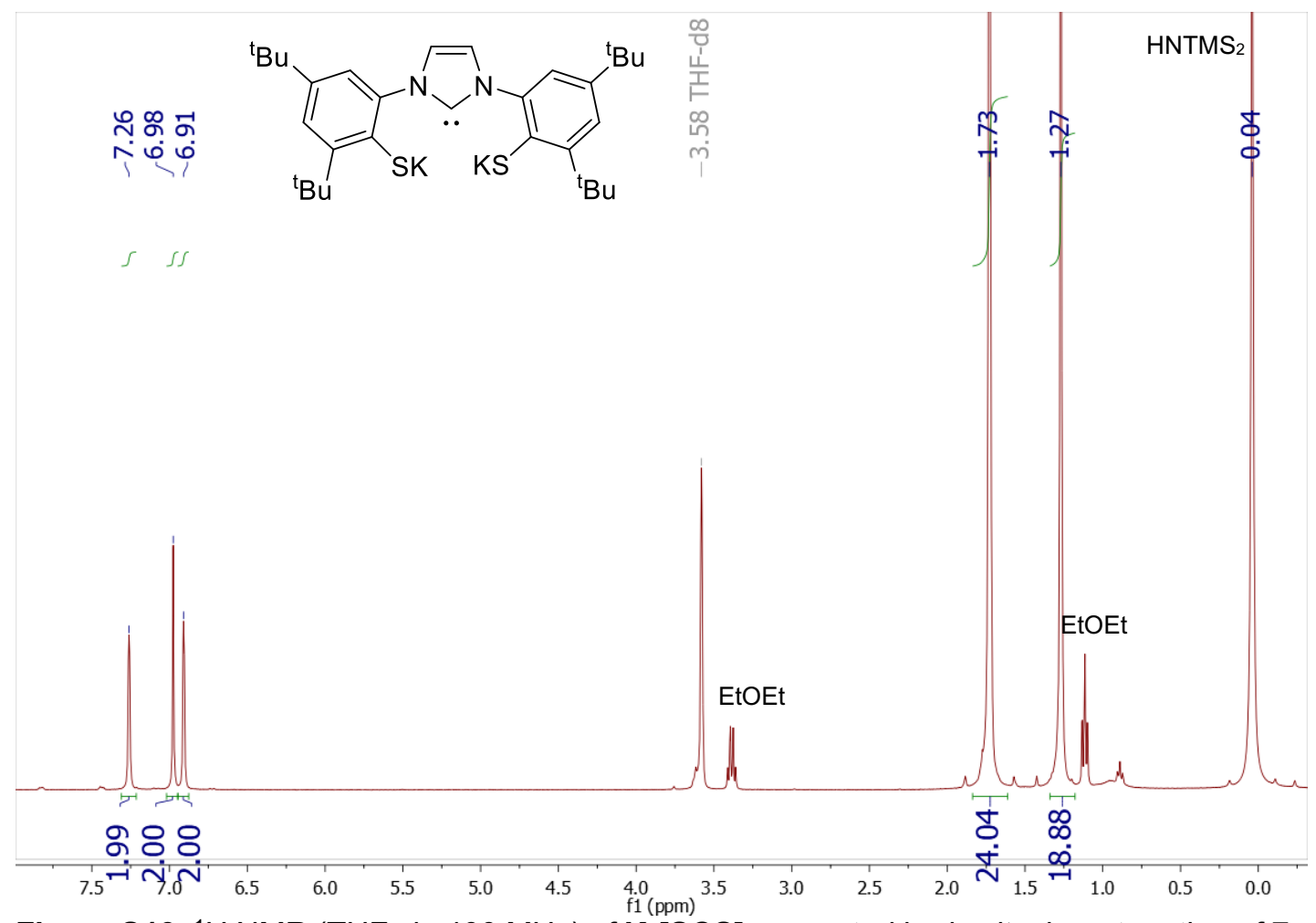

Figure S13. ${ }^{1} \mathrm{H}$ NMR (THF- $d_{8}, 400 \mathrm{MHz}$ ) of $\mathbf{K}_{2}$ [SCS] generated by in situ deprotonation of 7 with one equiv of KHMDS. The tert-butyl resonance at $1.73 \mathrm{ppm}$ overlaps with the THF solvent peak.

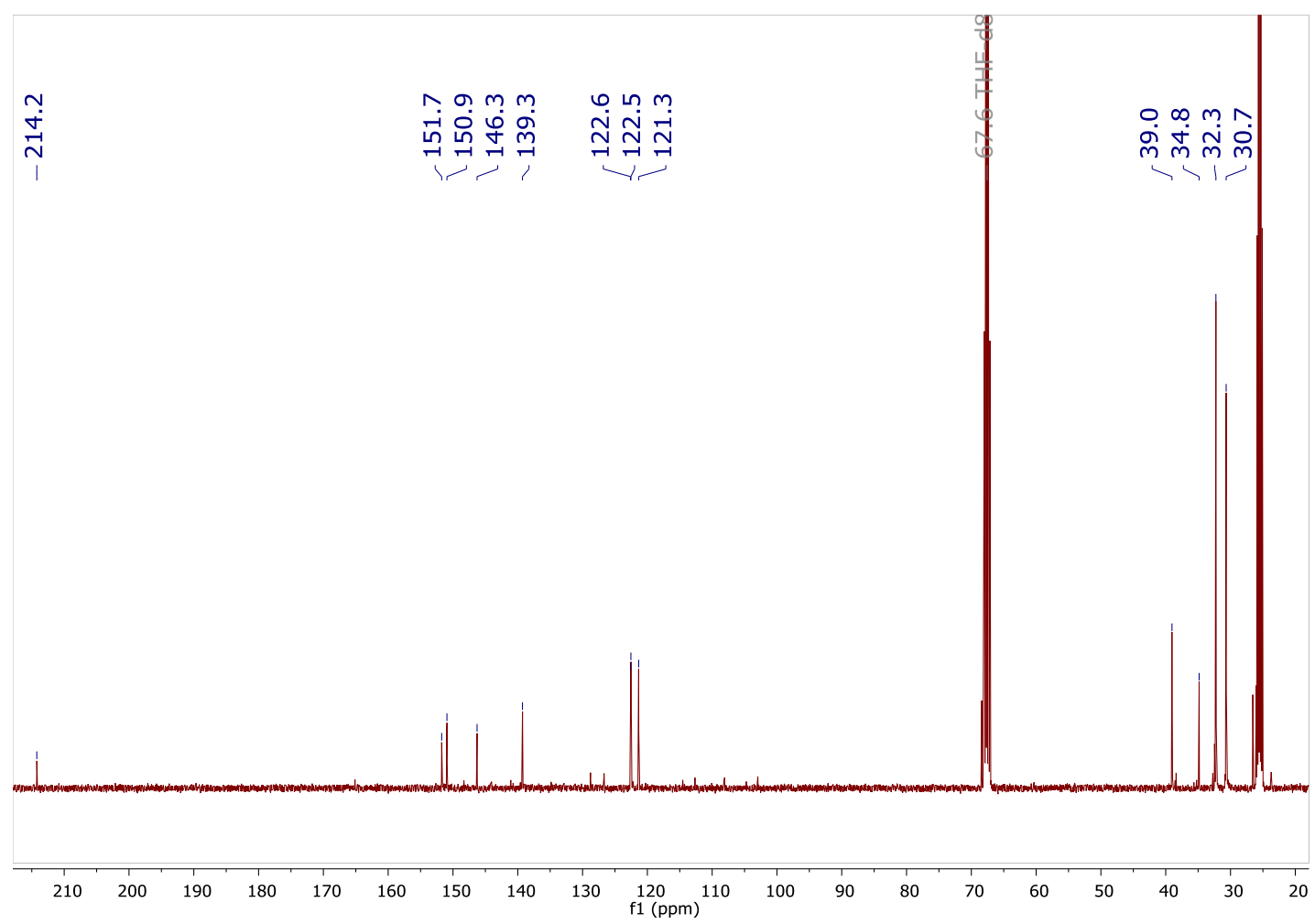

Figure S14. ${ }^{13} \mathrm{C}$ NMR $\left(\mathrm{THF}-d_{8}, 101 \mathrm{MHz}\right)$ of 7 after treatment with one equiv of KHMDS. 


\section{Synthesis and Characterization of Bis(thioether) NHC Iron Complexes}

\section{Synthesis and Characterization of Bis(thioether) NHC Iron Complexes}

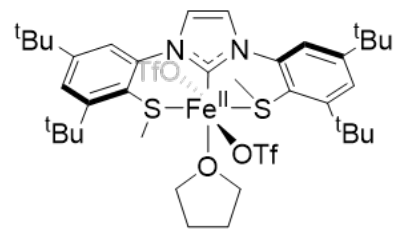

Synthesis of 8. An $88.1 \mathrm{mg}(0.202 \mathrm{mmol})$ portion of $\mathrm{Fe}\left(\mathrm{CH}_{3} \mathrm{CN}\right)_{2}(\mathrm{OTf})_{2}$ was coevaporated twice with THF. The resulting material was dissolved in $10 \mathrm{~mL}$ of THF and cooled to $-78{ }^{\circ} \mathrm{C}$. A cold suspension of $110.3 \mathrm{mg}(0.200 \mathrm{mmol})$ $\mathbf{S}^{\mathrm{Me}} \mathbf{C S}^{\mathrm{Me}} \cdot 0.2 \mathrm{Et}_{2} \mathrm{O}$ in $15 \mathrm{~mL}$ of THF was added dropwise to this suspension. The reaction mixture was stirred for $1 \mathrm{~h}$ at $-78{ }^{\circ} \mathrm{C}$ and then warmed to room temperature. The solvent was removed under vacuum giving an off-white solid which was redissolved in $5 \mathrm{~mL}$ of THF, filtered through Celite, and layered with $15 \mathrm{~mL}$ of pentane. After standing overnight at $-40^{\circ} \mathrm{C}$, a white powder precipitated. The solvent was decanted off and the solid was washed with $3 \times 1 \mathrm{~mL}$ of pentane and dried under vacuum, affording $157 \mathrm{mg}$ of crude $\mathbf{8}$. We were unable to fully purify 8 due to the similar solubility of impurities (particularly protonated ligand and $\left.\mathrm{Fe}(\mathrm{OTf})_{2}\right)$ to the desired complex. Furthermore, upon standing at room temperature solutions of 8 in THF slowly turned green; based on ${ }^{1} \mathrm{H}$ NMR spectroscopy, the new product is tentatively assigned as $\left[\mathrm{Fe}\left(\mathbf{S}^{\mathrm{Me}} \mathbf{C} \mathbf{S}^{\mathrm{Me}}\right)_{2}\right](\mathrm{OTf})_{2}$. As discussed in the main text, in solution 8 consists of two species.

${ }^{1} \mathrm{H}$ NMR (THF- $d_{8}, 400 \mathrm{MHz}$ ): 105.7 (major species, 6H), 103.9 (major species, 2H), 24.6 (minor species, $2 \mathrm{H}$ ), 24.0 (major species, 2H), 15.5 (major species, 2H), 11.0 (major species, $18 \mathrm{H}$ ), 10.0 (minor species, $2 \mathrm{H}$ ), 4.4 (minor species, $3 \mathrm{H}$ ), 0.3 (minor species, $18 \mathrm{H}$ ), 0.2 (minor species, $18 \mathrm{H}$ ), -0.4 (major species, $18 \mathrm{H}$ ) ppm. See below for a more detailed discussion of the ${ }^{1} \mathrm{H}$ NMR spectroscopic assignments.

${ }^{19} \mathrm{~F}$ NMR (THF-d8, $376 \mathrm{MHz}$ ): -7.8 (major species), -33 (minor species) See below for a more detailed discussion of the ${ }^{19} \mathrm{~F}$ NMR spectroscopic assignments.

Mössbauer (solid state): $\delta=1.10 \mathrm{~mm} / \mathrm{s},\left|\Delta E_{\mathrm{Q}}\right|=3.74 \mathrm{~mm} / \mathrm{s}, \Gamma_{\mathrm{L}}=\Gamma_{\mathrm{R}}=0.28 \mathrm{~mm} / \mathrm{s}$.

Mössbauer (frozen THF solution): $\delta=1.07 \mathrm{~mm} / \mathrm{s},\left|\Delta E_{\mathrm{Q}}\right|=3.63 \mathrm{~mm} / \mathrm{s}, \Gamma_{\mathrm{L}}=\Gamma_{\mathrm{R}}=0.37 \mathrm{~mm} / \mathrm{s}(53 \%) ; \delta=1.11$ $\mathrm{mm} / \mathrm{s},\left|\Delta E_{\mathrm{Q}}\right|=2.16 \mathrm{~mm} / \mathrm{s}, \Gamma_{\mathrm{L}}=\Gamma_{\mathrm{R}}=0.56 \mathrm{~mm} / \mathrm{s}(47 \%)$.

FT-IR (cm-1): $2963(w), 2932(w), 2906(w), 2875(w), 1601(w), 1548(w), 1480(w), 1466(w, b r), 1421(\mathrm{~m})$, $1393(\mathrm{w}), 1360(\mathrm{w}), 1311(\mathrm{~m}), 1254(\mathrm{w}), 1232(\mathrm{~m}), 1205(\mathrm{~s}), 1170(\mathrm{~s}), 1105(\mathrm{~m}), 1015(\mathrm{~s}), 973(\mathrm{w}), 920(\mathrm{w}$, br), $885(w), 877(w), 842(w), 787(w), 761(w), 744(w), 724(m), 677(w), 657(w), 632(s), 581(w), 569$ (w), $553(\mathrm{w}), 510(\mathrm{~m})$.

Analysis of the ${ }^{1} \mathrm{H}$ NMR spectrum of 8 in THF-d8. The ${ }^{1} \mathrm{H}$ NMR spectrum of 8 (Figure S15) indicates the presence of multiple paramagnetic species. There are also diamagnetic species present (see inset of Figure S15), including protonated ligand and pentane. The region between 2 and 3 ppm contains additional peaks which were not fit due to their low intensity. The integrated areas for all peaks are given in Table S1. Overlapping peaks were deconvoluted using the line fitting feature in MesReNova version 12.0.1. Based on their relative areas, the peaks can be assigned to a major (blue) and minor (orange) species. A complete set of resonances $(3 \times 2 \mathrm{H}, 2 \times 18 \mathrm{H}$, and $1 \times 6 \mathrm{H})$ can be identified for the major species. For the minor species, resonances for two of the three aryl/NHC backbone protons and both sets of tert-butyl protons can be assigned. The peak at $4.4 \mathrm{ppm}$ that integrates to $3 \mathrm{H}$ is tentatively assigned to an $\mathrm{SCH}_{3}$ group, implying inequivalence of the thioethers in the minor species. The remaining peaks are either in the set of unresolved peaks between 0 and 4 ppm, overlap with other peaks, or are broadened beyond detection.

Analysis of the ${ }^{19} \mathrm{~F}$ NMR spectrum of 8 in THF-d8. The ${ }^{19} \mathrm{~F}$ NMR spectrum of 8 has three broad resonances (Figure S16). The small peak at $-10 \mathrm{ppm}$ accounting for $4 \%$ of the total area (see Table S2) is assigned to $\mathrm{Fe}(\mathrm{OTf})_{2}$; this was confirmed by spiking an NMR sample with $\mathrm{Fe}(\mathrm{OTf})_{2}$. The relatively sharp peak at $-8 \mathrm{ppm}$ accounts for approximately $70 \%$ of the remaining area, and the much broader peak at -33 ppm accounts for the remaining $26 \%$ (see Table S2). Presumably these ${ }^{19} \mathrm{~F}$ peaks correspond to the major and minor species observed in the ${ }^{1} \mathrm{H}$ NMR spectrum since both spectra indicate the presence of two species in a 7:3 ratio. 


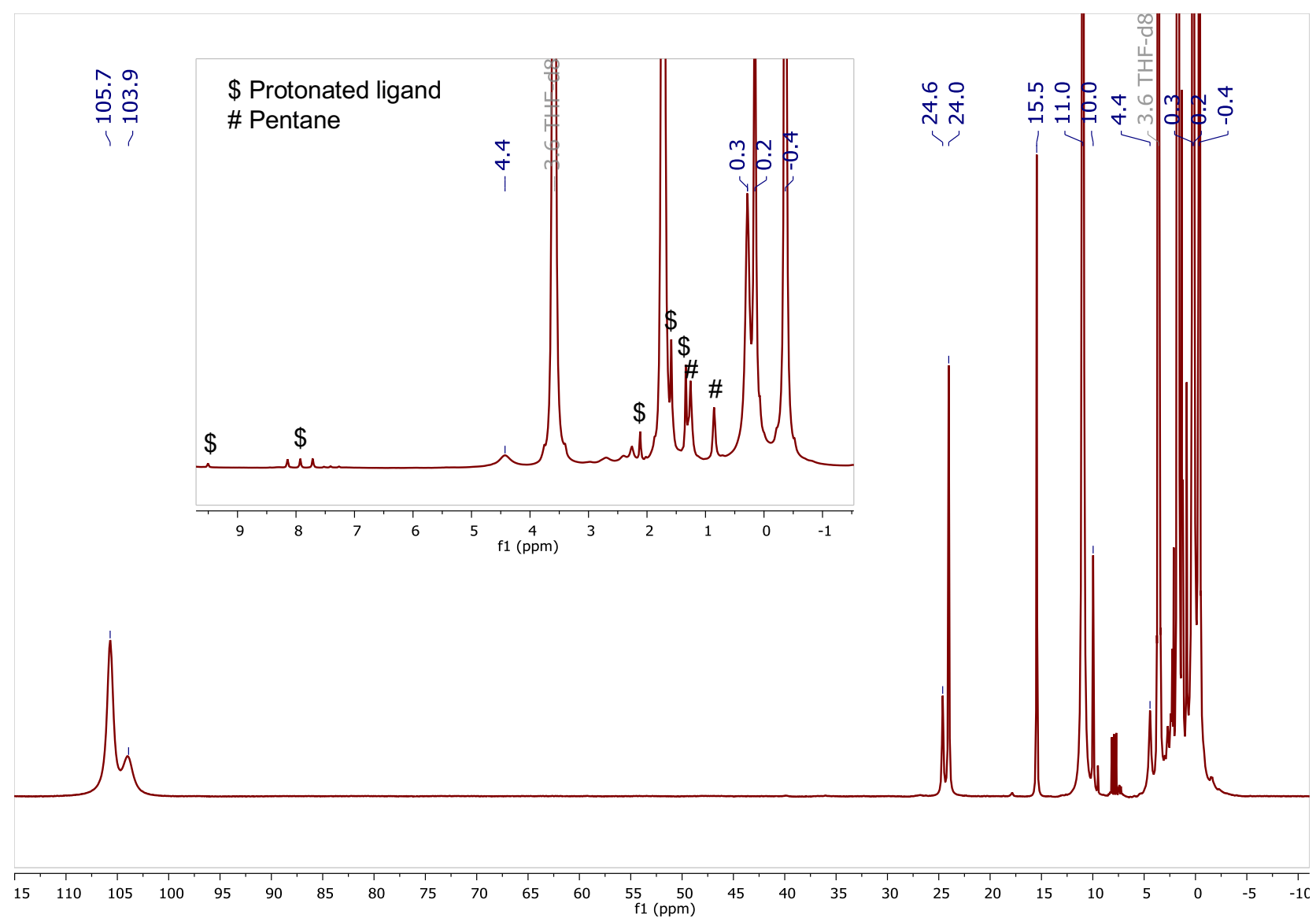

Figure S15. ${ }^{1} \mathrm{H}$ NMR spectrum of 8 in THF- $d_{8}$ at $25^{\circ} \mathrm{C}$. The diamagnetic region is shown in the inset. Protonated ligand (marked with $\$$ ) is present as an approximately $3 \%$ impurity along with a small amount of pentane (marked with \#).

Table S1. Integrated areas used for assignment of ${ }^{1} \mathrm{H}$ NMR spectrum of 8.

\begin{tabular}{|c|c|c|c|c|}
\hline $\begin{array}{c}\text { Peak position } \\
\text { (ppm) }\end{array}$ & Area & $\begin{array}{c}\text { Normalized for } \\
\text { major species }^{\mathbf{a}}\end{array}$ & $\begin{array}{c}\text { Normalized for } \\
\text { minor species }^{\mathbf{b}}\end{array}$ & Peak assignment \\
\hline 105.7 & 155034 & 5.9 & 13.9 & S-Me \\
\hline 103.9 & 49272 & 1.9 & 4.4 & Aryl or NHC backbone \\
\hline 24.6 & 22380 & 0.9 & 2.0 & Aryl or NHC backbone \\
\hline 24.0 & 52503 & 2.0 & 4.7 & Aryl or NHC backbone \\
\hline 15.5 & 51098 & 1.9 & 4.6 & Aryl or NHC backbone \\
\hline 11.0 & 476140 & 18.1 & 42.6 & Tert-butyl \\
\hline 10.0 & 21894 & 0.8 & 2.0 & Aryl or NHC backbone \\
\hline 4.4 & 34927 & 1.3 & 3.1 & S-Me (tentative) \\
\hline 0.3 & 225401 & 8.6 & 20.1 & Tert-butyl \\
\hline 0.2 & 220856 & 8.4 & 19.7 & Tert-butyl \\
\hline-0.4 & 494792 & 18.8 & 44.2 & Tert-butyl \\
\hline
\end{tabular}

a Based on setting the peak at $24.0 \mathrm{ppm}$ to $2 \mathrm{H}$. ${ }^{\mathrm{b}}$ Based on setting the peak at $24.6 \mathrm{ppm}$ to $2 \mathrm{H}$. 


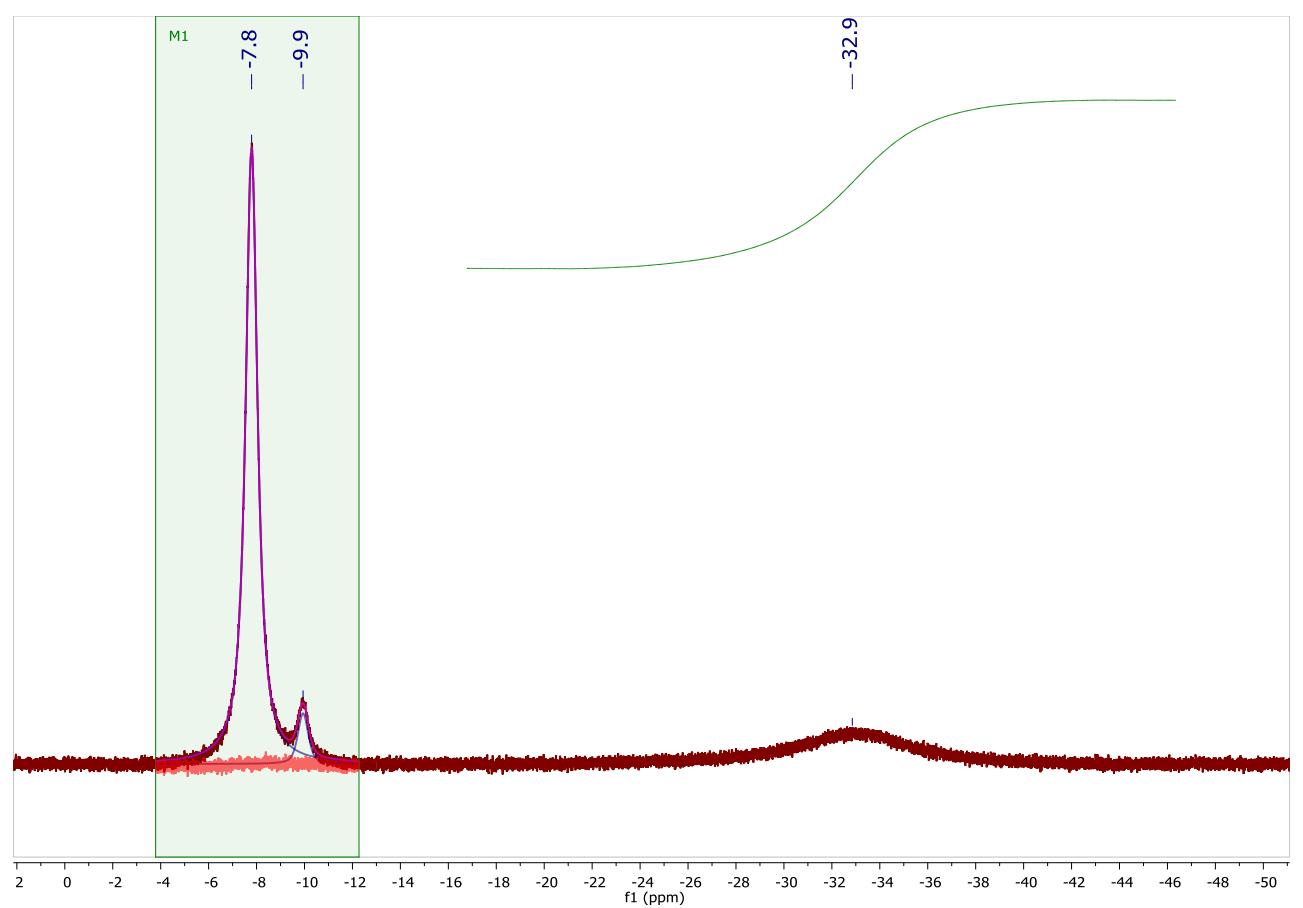

Figure S16. ${ }^{19} \mathrm{~F}$ NMR spectrum of 8 in THF-d8 at $25^{\circ} \mathrm{C}$. The line fitting feature in MesReNova was used to deconvolute the peaks at -7.8 and $-9.9 \mathrm{ppm}$.

Table S2. Integrated peak areas for ${ }^{19} \mathrm{~F}$ NMR spectrum of 8 in THF-d8.

\begin{tabular}{|c|c|c|}
\hline $\begin{array}{c}\text { Peak position } \\
\text { (ppm) }\end{array}$ & Area & $\begin{array}{c}\text { Normalized } \\
\text { area }\end{array}$ \\
\hline-7.8 & 1470191 & 0.70 \\
\hline-9.9 & 90664 & 0.04 \\
\hline-33 & 544684 & 0.26 \\
\hline
\end{tabular}




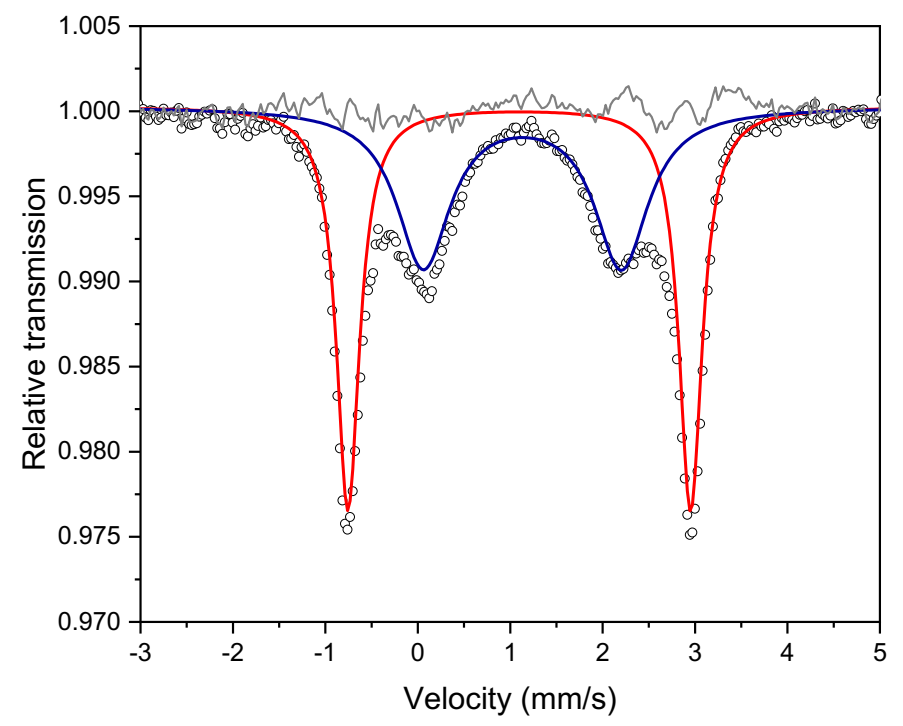

Figure S17. Mössbauer spectrum of solid $\mathbf{8}$ generated by drying a THF solution of $\mathbf{9}$ under vacuum. The circles correspond to experimental data, the solid red and blue lines are fits, and the grey line is the residual.

Fit parameters (red line, $53 \%$ ): $\delta=1.10 \mathrm{~mm} / \mathrm{s} ;\left|\Delta E_{\mathrm{Q}}\right|=3.71 \mathrm{~mm} / \mathrm{s} ; \Gamma_{\mathrm{L}}=\Gamma_{\mathrm{R}}=0.30$.

Fit parameters (blue line, $47 \%$ ): $\delta=1.13 \mathrm{~mm} / \mathrm{s} ;\left|\Delta E_{\mathrm{Q}}\right|=2.14 \mathrm{~mm} / \mathrm{s} ; \Gamma_{\mathrm{L}}=\Gamma_{\mathrm{R}}=0.70$.

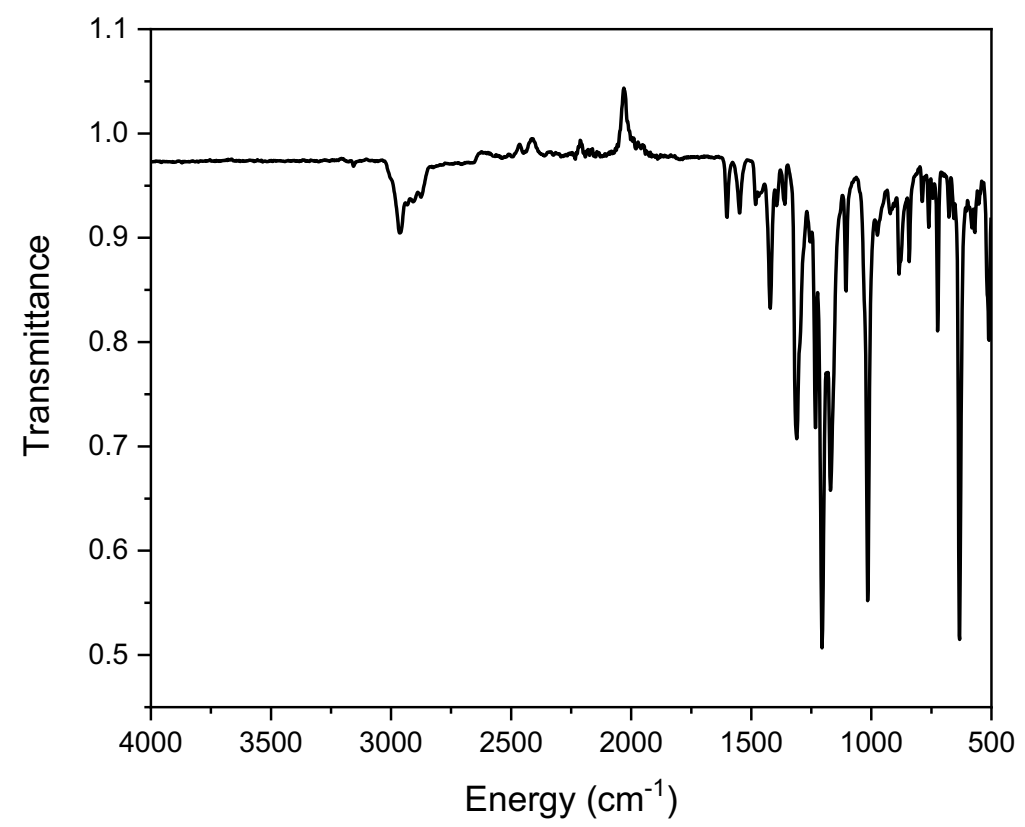

Figure S18. FT-IR spectrum of solid 8. 
$2^{-}$OTf Synthesis of 9 . An $83 \mathrm{mg}(0.19 \mathrm{mmol})$ portion of $\mathrm{Fe}\left(\mathrm{CH}_{3} \mathrm{CN}\right)_{2}(\mathrm{OTf})_{2}$ was co-

$72^{+}$evaporated twice with THF. The resulting material was dissolved in $5 \mathrm{~mL}$ of

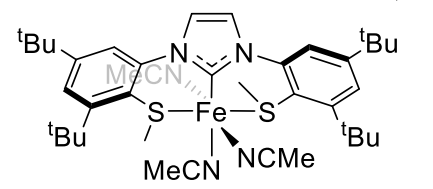

THF and cooled to $-78{ }^{\circ} \mathrm{C}$ which caused partial precipitation. A cold suspension of $102 \mathrm{mg} \mathrm{S}^{\mathrm{Me}} \mathbf{C S}^{\mathrm{Me}}(0.19 \mathrm{mmol}, 1.0$ equiv) in $10 \mathrm{~mL}$ of THF was added dropwise to this suspension. The reaction mixture was stirred for $1 \mathrm{~h}$ at $-78{ }^{\circ} \mathrm{C}$ and then warmed to room temperature at which point the solution became light yellow and homogeneous. The solvent was removed under vacuum and the resulting off-white material was dissolved in $5 \mathrm{~mL}$ of $\mathrm{CH}_{3} \mathrm{CN}$, causing a color change to dark purple. The solution was filtered through Celite, concentrated to $2 \mathrm{~mL}$, and layered with $15 \mathrm{~mL}$ of diethyl ether. After standing for 24 hours at $-40^{\circ} \mathrm{C}$, purple block crystals formed. The mother liquor was decanted off and the crystals were washed with diethyl ether $(3 \times 1 \mathrm{~mL})$ and then crushed and dried under vacuum, affording 9 as a purple solid. Yield: $163 \mathrm{mg}$ (84\% yield).

${ }^{1} \mathrm{H} \mathrm{NMR}\left(\mathrm{CD}_{3} \mathrm{CN}, 400 \mathrm{MHz}\right): 8.30$ (s, 2H), 7.69 (d, J = 1.6 Hz, 2H), 7.63 (d, J = 1.6 Hz, 2H), $1.96\left(\mathrm{~s}, \mathrm{CH}_{3} \mathrm{CN}\right)$, $1.87(\mathrm{~s}, 6 \mathrm{H}), 1.64(\mathrm{~s}, 18 \mathrm{H}), 1.40(\mathrm{~s}, 18 \mathrm{H}) \mathrm{ppm}$.

${ }^{13} \mathrm{C}\left\{{ }^{1} \mathrm{H}\right\}$ NMR $\left(\mathrm{CD}_{3} \mathrm{CN}, 101 \mathrm{MHz}\right): 197.4,156.3,153.3,143.5,138.2,129.7,126.2,124.7,121.6,118.8$, 38.4, 36.3, 31.5, 31.0, $20.7 \mathrm{ppm}$.

${ }^{19} \mathrm{~F} \mathrm{NMR}\left(\mathrm{CD}_{3} \mathrm{CN}, 376 \mathrm{MHz}\right):-80.2 \mathrm{ppm}$.

Anal. Calcd for $\mathrm{C}_{41} \mathrm{H}_{57} \mathrm{~F}_{6} \mathrm{FeN}_{5} \mathrm{O}_{6} \mathrm{~S}_{4}$ : C, 48.56; $\mathrm{H}, 5.67 ; \mathrm{N}, 6.91$. Found: $\mathrm{C}, 48.46 ; \mathrm{H}, 5.52 ; \mathrm{N}, 6.64$.

Mössbauer (solid-state): $\delta=0.38 \mathrm{~mm} / \mathrm{s} ;\left|\Delta E_{\mathrm{Q}}\right|=1.41 \mathrm{~mm} / \mathrm{s} ; \Gamma_{\mathrm{L}}=\Gamma_{\mathrm{R}}=0.30 \mathrm{~mm} / \mathrm{s}$.

UV-Vis $\left(\mathrm{CH}_{3} \mathrm{CN}\right): 250 \mathrm{~nm}$ (sh, $\left.\varepsilon=28,400 \mathrm{M}^{-1} \mathrm{~cm}^{-1}\right), 275 \mathrm{~nm}$ (sh, $\left.\varepsilon=17,100 \mathrm{M}^{-1} \mathrm{~cm}^{-1}\right), 296 \mathrm{~nm}$ (sh, $\varepsilon=7,900$ $\left.\mathrm{M}^{-1} \mathrm{~cm}^{-1}\right) 363 \mathrm{~nm}\left(\varepsilon=1,170 \mathrm{M}^{-1} \mathrm{~cm}^{-1}\right), 536 \mathrm{~nm}\left(\varepsilon=560 \mathrm{M}^{-1} \mathrm{~cm}^{-1}\right)$.

FT-IR (cm $\left.{ }^{-1}\right): 2959(w), 2932(w), 2912(w), 2873(w), 1597(w), 1556(w), 1480(w), 1421(m), 1397(w)$, $1364(w), 1329(w), 1301(w), 1256(s), 1219(m), 1146(s), 1117(m), 1030(s), 962(w), 926(w), 903(w)$, $877(w), 840(w), 787(w), 750(w, b r), 703(w), 661(w), 636(m), 571(m), 553(w), 516(m)$. 


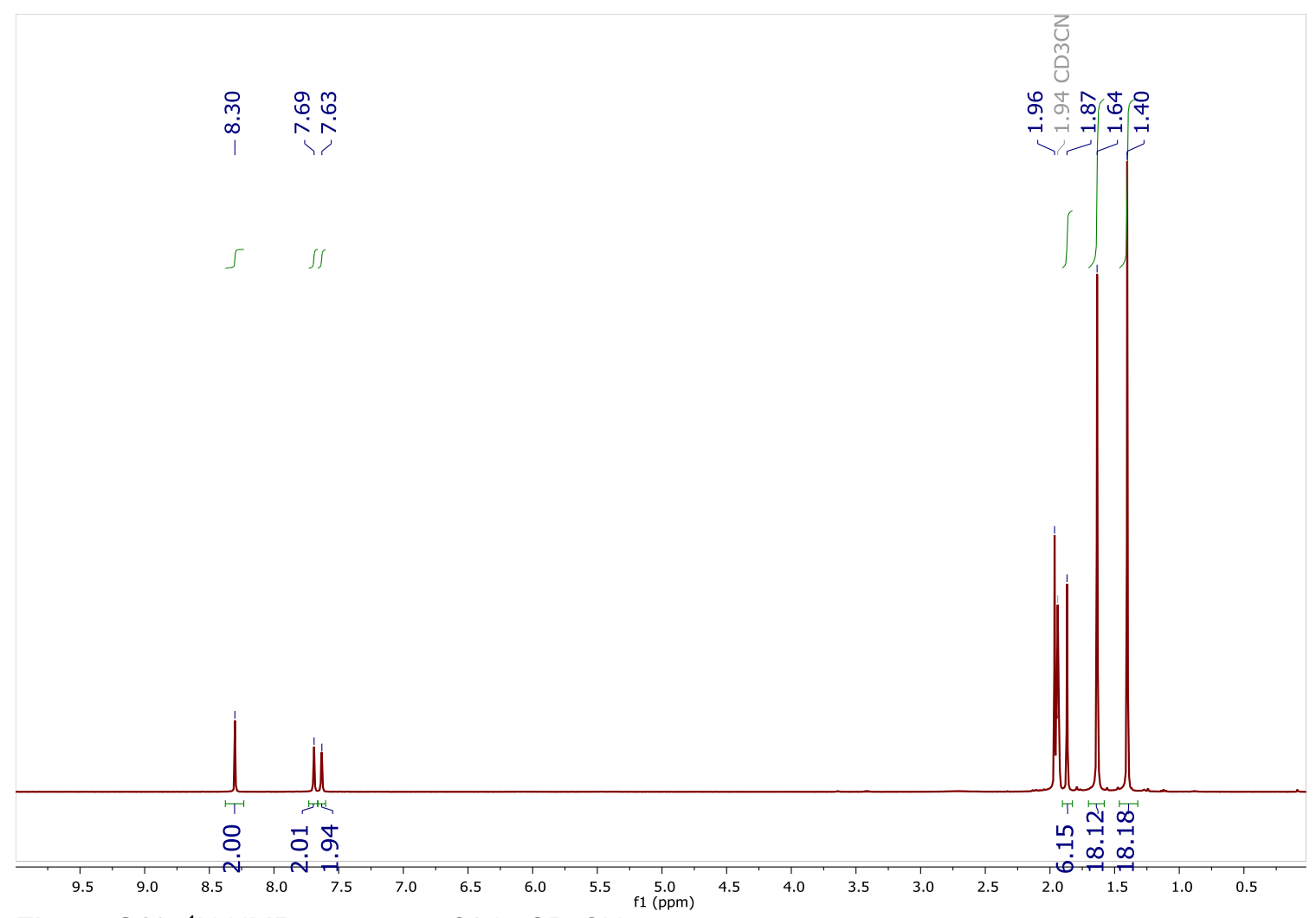

Figure S19. ${ }^{1} \mathrm{H}$ NMR spectrum of 9 in $\mathrm{CD}_{3} \mathrm{CN}$.

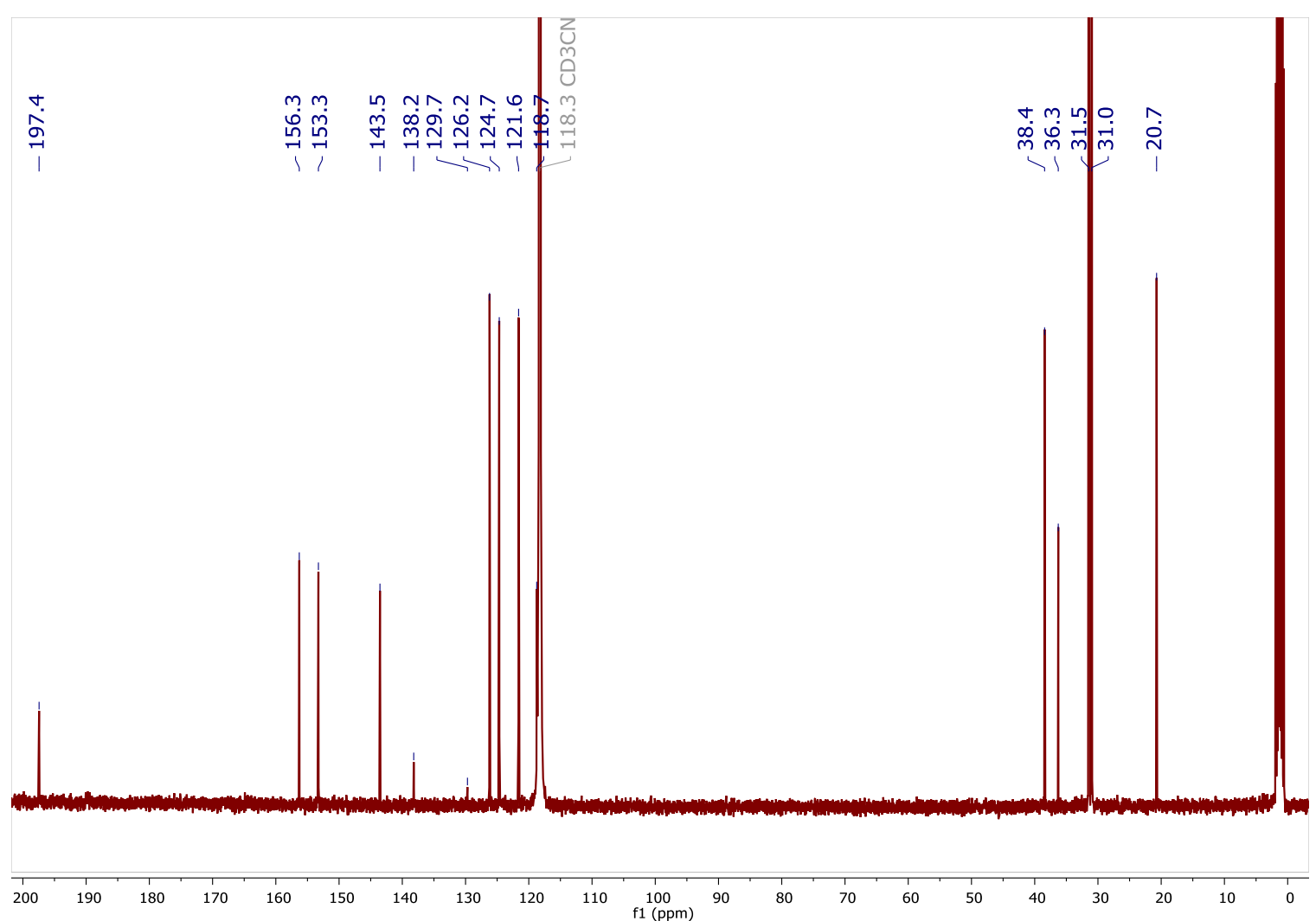

Figure S20. ${ }^{13} \mathrm{C}\left\{{ }^{1} \mathrm{H}\right\}$ NMR spectrum of 9 in $\mathrm{CD}_{3} \mathrm{CN}$. 


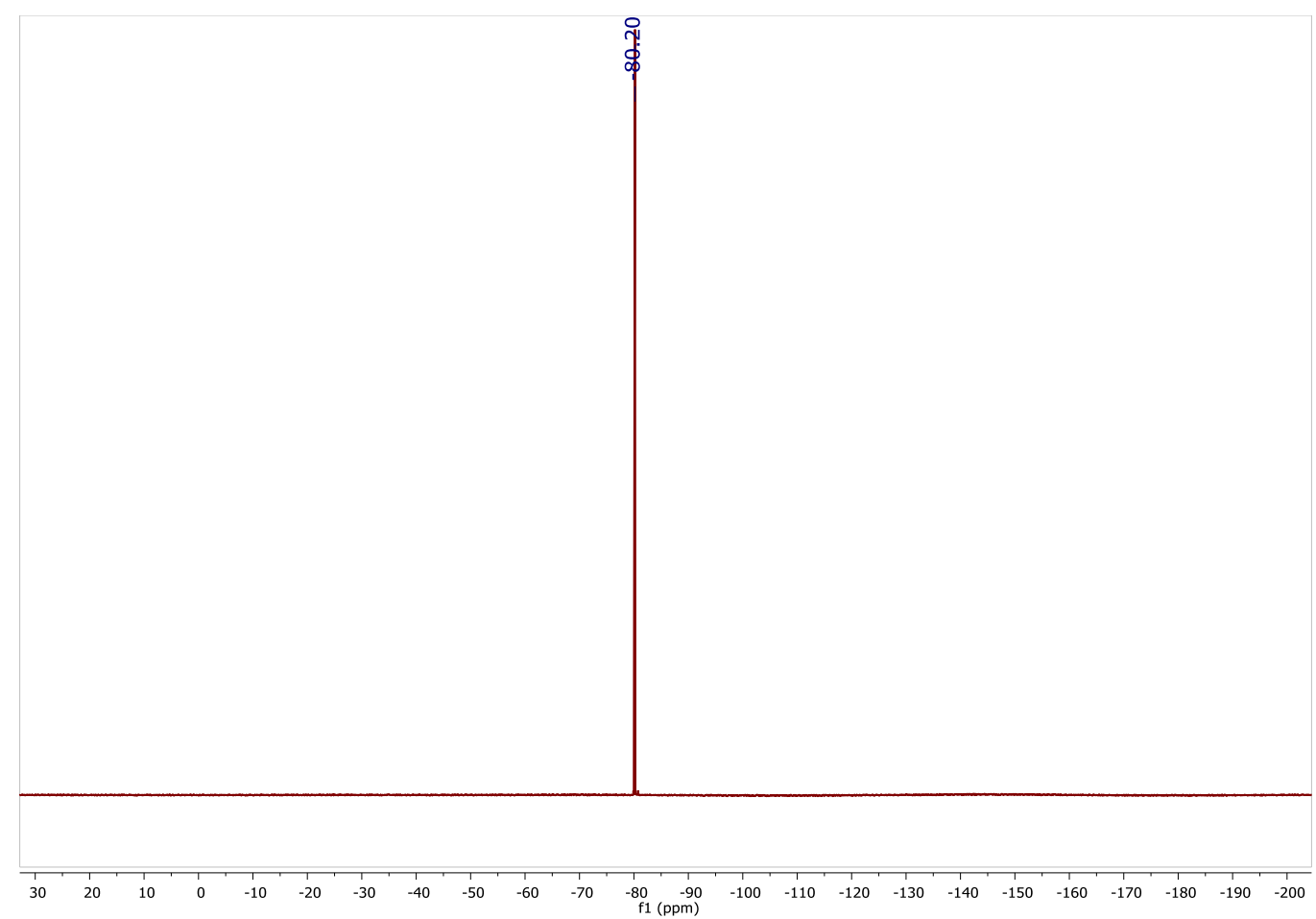

Figure S21. ${ }^{19} \mathrm{~F}$ NMR spectrum of 9.

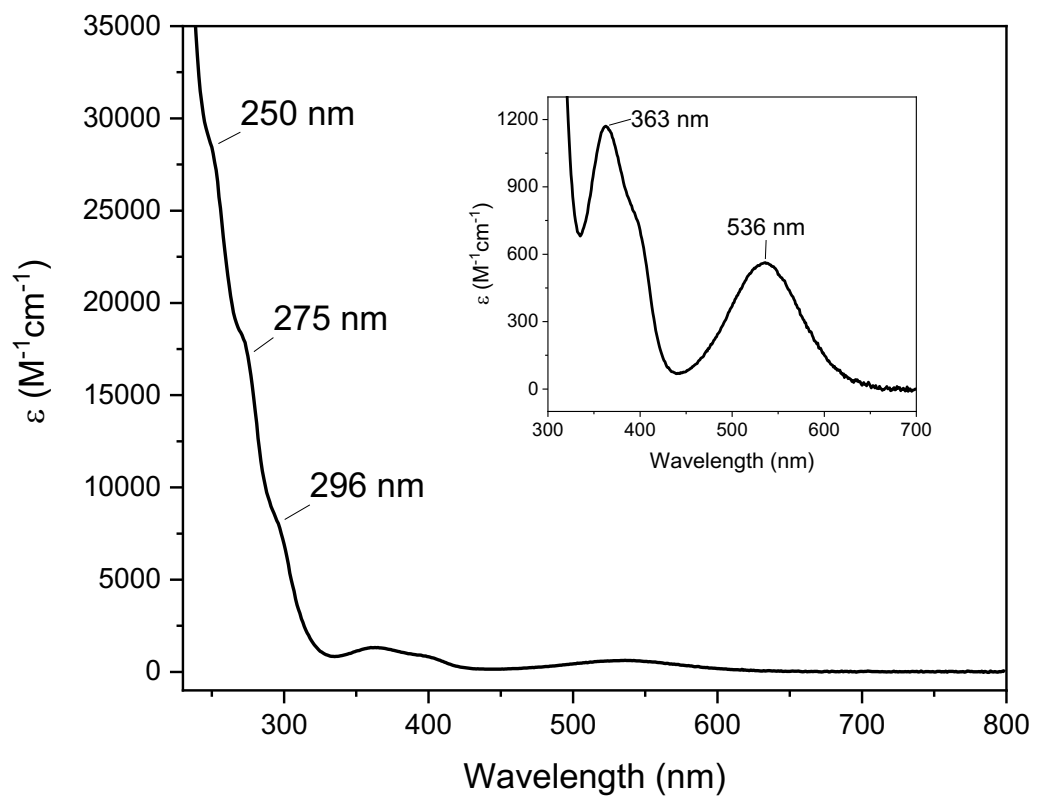

Figure S22. UV-Vis spectrum of 9 in $\mathrm{CH}_{3} \mathrm{CN}$. The low-intensity features in the $300-600 \mathrm{~nm}$ region are shown in the inset. 


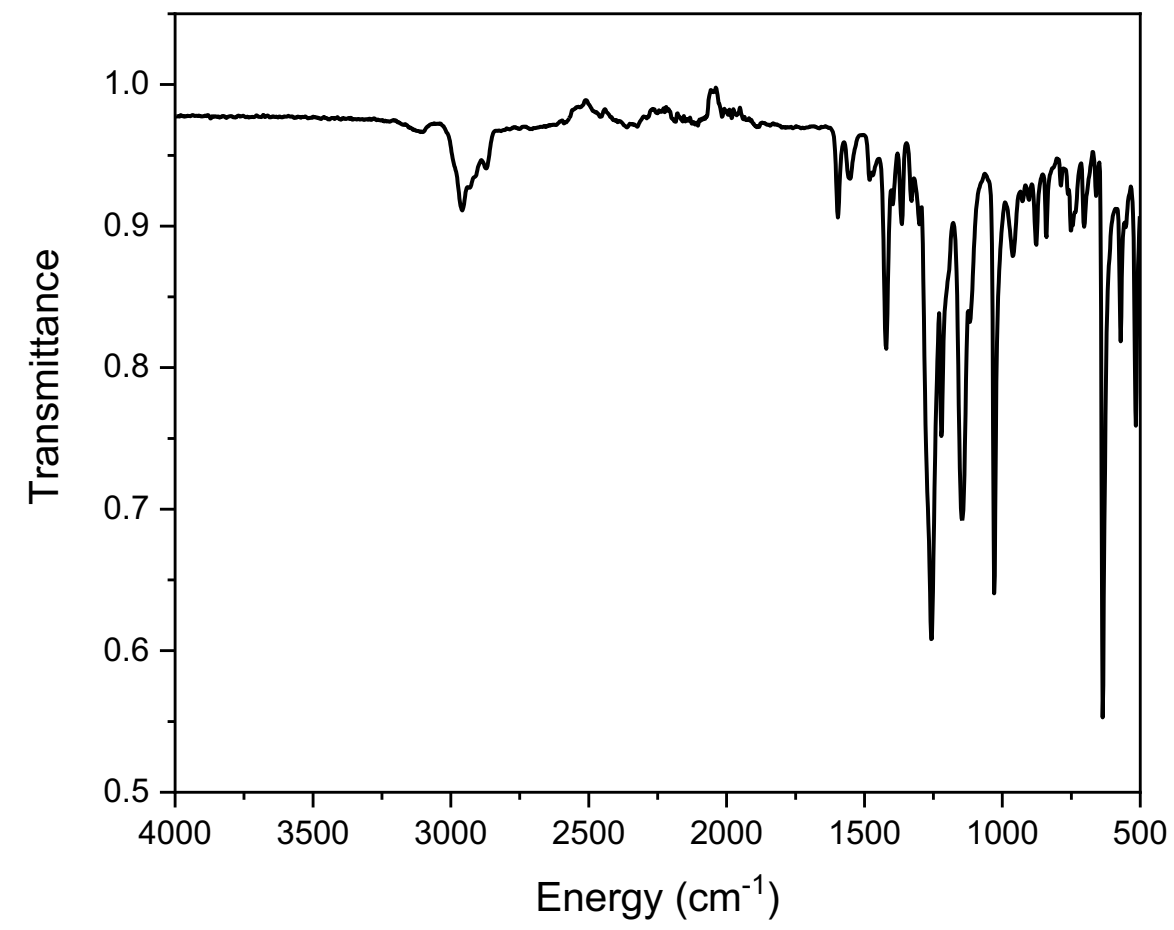

Figure S23. FT-IR spectrum of 9. 


\section{$\mathrm{N}_{2}$ Reduction Attempts with Compound 8}

Ammonia was quantified using the indophenol method ${ }^{15}$ and hydrazine was quantified using a colorimetric assay.$^{16}$ We note that these assays can give false positives under some circumstances. Furthermore, some or all of the observed $\mathrm{N}$-containing products could come from ligand decomposition, the conjugate base of $\mathrm{N}$-containing acids, or other $\mathrm{N}$-containing impurities. Due to the very small amount of $\mathrm{NH}_{3}$ and $\mathrm{N}_{2} \mathrm{H}_{4}$ formed in these reactions, we did not perform follow-up experiments to unambiguously determine that the observed positive signals arise from $\mathrm{N}_{2}$-derived $\mathrm{NH}_{3}$ and $\mathrm{N}_{2} \mathrm{H}_{4}$. The values given here should therefore be taken as an upper limit on the yields of $\mathrm{NH}_{3}$ and $\mathrm{N}_{2} \mathrm{H}_{4}$.

\section{Representative procedure for $\mathrm{N}_{2}$ reduction attempt using 9 as a pre-catalyst and $\left[\mathrm{H}\left(\mathrm{OEt}_{2}\right)_{2}\right]$ [BAr $\left.{ }_{4}\right]$} as acid. A $20 \mathrm{~mL}$ flask equipped with a Teflon high vacuum valve was charged with $6.7 \mathrm{mg}(6.6 \mu \mathrm{mol})$ of 9. THF was added, resulting in formation of a colorless solution. The volatile materials were removed under vacuum, giving a pale pink solid. This procedure was repeated two more times to give $\mathbf{8}$ as a white solid. This material was redissolved in $2 \mathrm{~mL}$ of THF, and the flask was cooled to $-80^{\circ} \mathrm{C}$ in a dry ice/acetonecooled glovebox cold well. The Teflon valve was removed and $5.5 \mathrm{mg}\left(41 \mu \mathrm{mol}, 6.2\right.$ equiv) of $\mathrm{KC}_{8}$ in 0.5

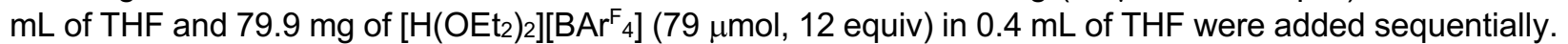
The Teflon valve was sealed and the resulting suspension was stirred in the cold well for 2 hours. The reaction mixture was then warmed to room temperature, transferred out of the glovebox, and frozen in liquid nitrogen. The Teflon valve was removed and $1.5 \mathrm{~mL}$ of $0.17 \mathrm{M}$ sodium tert-butoxide in THF $(255 \mu \mathrm{mol})$ was added. The valve was replaced, and after the solution had fully frozen, the flask was evacuated and then sealed. The flask was warmed to room temperature and the solution was stirred for $1 \mathrm{~h}$. The contents of the flask were vacuum transferred to a flask containing $2 \mathrm{~mL}$ of a $2 \mathrm{M}$ solution of $\mathrm{HCl}$ in diethyl ether. The volatile materials in the receiving flask were removed under vacuum, and the residue in the flask was dissolved in $10 \mathrm{~mL}$ of phosphate-buffered water $(\mathrm{pH}=7.1)$ for ammonia and hydrazine analysis.

Scheme S1. $\mathrm{NH}_{3}$ and $\mathrm{N}_{2} \mathrm{H}_{4}$ yields (per iron) using 9 as a pre-catalyst for $\mathrm{N}_{2}$ reduction.

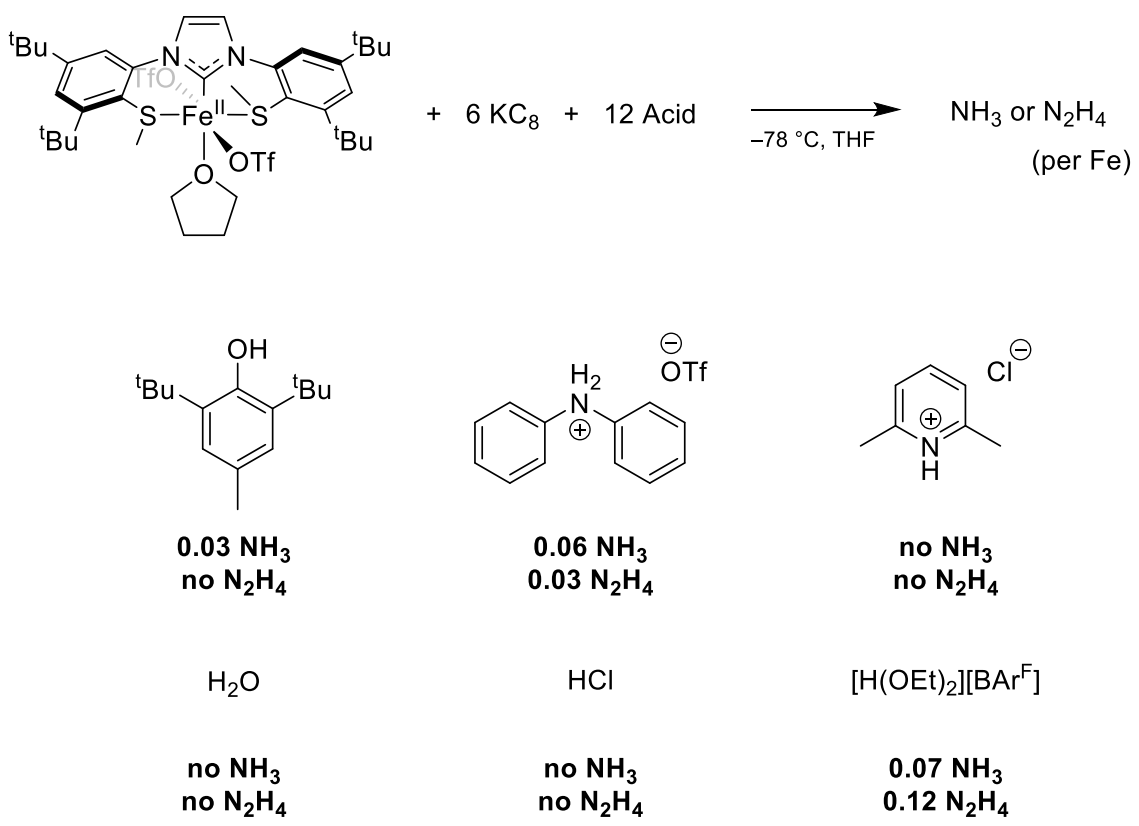




\section{Synthesis, Characterization, and Reactivity of Bis(thiolate) NHC Iron Complexes}

Synthesis of Bis(thiolate) NHC Iron Complexes

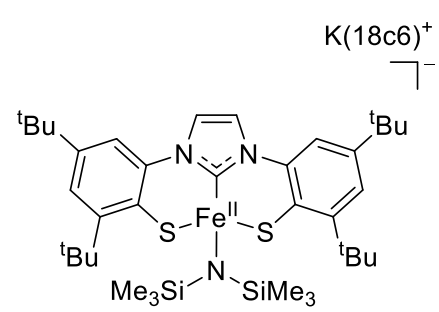

Synthesis of 10. A solution of $150.1 \mathrm{mg}(0.257 \mathrm{mmol}) \mathbf{7} \cdot 0.5 \mathrm{THF}$ in $5 \mathrm{~mL}$ of THF was added dropwise to a solution of $108.1 \mathrm{mg}(0.257 \mathrm{mmol})$ $\mathrm{Fe}(\mathrm{HMDS})_{2}(\mathrm{THF})_{0.6}$ in $5 \mathrm{~mL}$ of THF, resulting in rapid formation of an orange solution. After $10 \mathrm{~min}, 75.4 \mathrm{mg}(0.285 \mathrm{mmol}, 1.1$ equiv) of solid 18-crown-6 was added. After 1 hour, the volatile materials were removed under vacuum to afford a brown oil. Hexanes $(5 \mathrm{~mL})$ was added, resulting in formation of a yellow powder. The volatile materials were again removed under vacuum. The resulting material was suspended in $3 \mathrm{~mL}$ of diethyl ether and filtered. The powder was washed with $3 \times 1 \mathrm{~mL}$ of diethyl ether. A second crop of material was collected by drying the filtrate under vacuum, redissolving in diethyl ether, and placing in $\mathrm{a}-40^{\circ} \mathrm{C}$ freezer overnight. The mother liquor was decanted and the solid was washed with $3 \times 1 \mathrm{~mL}$ of diethyl ether. The combined material was dried under vacuum, yielding $227.4 \mathrm{mg}$ ( $86 \%$ yield) of the title compound as a yellow solid.

${ }^{1} \mathrm{H}$ NMR ( $\left.\mathrm{C}_{6} \mathrm{D}_{6}, 400 \mathrm{MHz}\right): 77.7(2 \mathrm{H}), 23.5(2 \mathrm{H}), 14.2(2 \mathrm{H}), 2.9(24 \mathrm{H}),-2.0(18 \mathrm{H}),-12.5(18 \mathrm{H})$ ppm. Note: A signal for the $\mathrm{NTMS}_{2}$ group is not observed in $\mathrm{C}_{6} \mathrm{D}_{6}$ (presumably due to extreme broadening) but can be observed as a broad peak at $18 \mathrm{ppm}$ in THF- $d_{8}$.

${ }^{1} \mathrm{H}$ NMR (THF-d $\left.d_{8}, 400 \mathrm{MHz}\right): 81.5(2 \mathrm{H}), 25.5(2 \mathrm{H}), 17.7\left(14 \mathrm{H}^{*}\right), 15.8(2 \mathrm{H}), 2.4(24 \mathrm{H}),-1.6(18 \mathrm{H}),-13.3$ $(18 \mathrm{H}) \mathrm{ppm}$. *The integrated intensity of the signal for the NTMS 2 group is low, likely due to its broadness which prevents reliable baseline correction.

Evans $\mu_{\mathrm{eff}}\left(\mathrm{C}_{6} \mathrm{D}_{6}, 25^{\circ} \mathrm{C}\right): 5.1(1) \mu_{\mathrm{B}}$.

Anal. Calcd. for $\mathrm{C}_{49} \mathrm{H}_{84} \mathrm{~N}_{3} \mathrm{~S}_{2} \mathrm{Si}_{2} \mathrm{O}_{6} \mathrm{KFe}$ : C, 57.34; H, 8.25; N, 4.09 Found: C, 57.39; $\mathrm{H}, 8.34 ; \mathrm{N}, 4.16$.

Mössbauer (solid-state): $\delta=0.67 \mathrm{~mm} / \mathrm{s} ;\left|\Delta E_{\mathrm{Q}}\right|=1.82 \mathrm{~mm} / \mathrm{s} ; \Gamma_{\mathrm{L}}=\Gamma_{\mathrm{R}}=0.30 \mathrm{~mm} / \mathrm{s}$.

Mössbauer $\left(8 \mathrm{mM}\right.$ in THF): $\delta=0.68 \mathrm{~mm} / \mathrm{s},\left|\Delta E_{Q}\right|=1.78 \mathrm{~mm} / \mathrm{s}, \Gamma \mathrm{L}=\Gamma_{\mathrm{R}}=0.31 \mathrm{~mm} / \mathrm{s}$.

UV-Vis (THF): $278 \mathrm{~nm}\left(\varepsilon=18,900 \mathrm{M}^{-1} \mathrm{~cm}^{-1}\right), 339 \mathrm{~nm}\left(\mathrm{sh}, \varepsilon=10,000 \mathrm{M}^{-1} \mathrm{~cm}^{-1}\right)$.

FT-IR (cm $\left.{ }^{-1}\right): 2946(\mathrm{~m}), 2895(\mathrm{~m}), 2885(\mathrm{~m}), 2871(\mathrm{~m}), 1601(\mathrm{w}), 1544(\mathrm{w}), 1531(\mathrm{w}), 1472(\mathrm{w}), 1454(\mathrm{w})$, $1415(\mathrm{~m}), 1389(\mathrm{w}), 1352(\mathrm{~m}), 1317(\mathrm{w}), 1293(\mathrm{w}), 1268(\mathrm{w}), 1244(\mathrm{~m}), 1234(\mathrm{w}), 1199(\mathrm{w}), 1182(\mathrm{w}), 1148$ $(\mathrm{w}), 1109(\mathrm{~s}), 1048(\mathrm{~m}), 1028(\mathrm{~s}), 962(\mathrm{~m}), 928(\mathrm{w}), 905(\mathrm{w}), 873(\mathrm{~s}), 828(\mathrm{~s}), 775(\mathrm{~m}), 744(\mathrm{~m}), 720(\mathrm{~m})$, $704(w), 675(m), 663(m), 646(m), 636(w), 606(w), 553(w), 528(w), 514(w)$. 


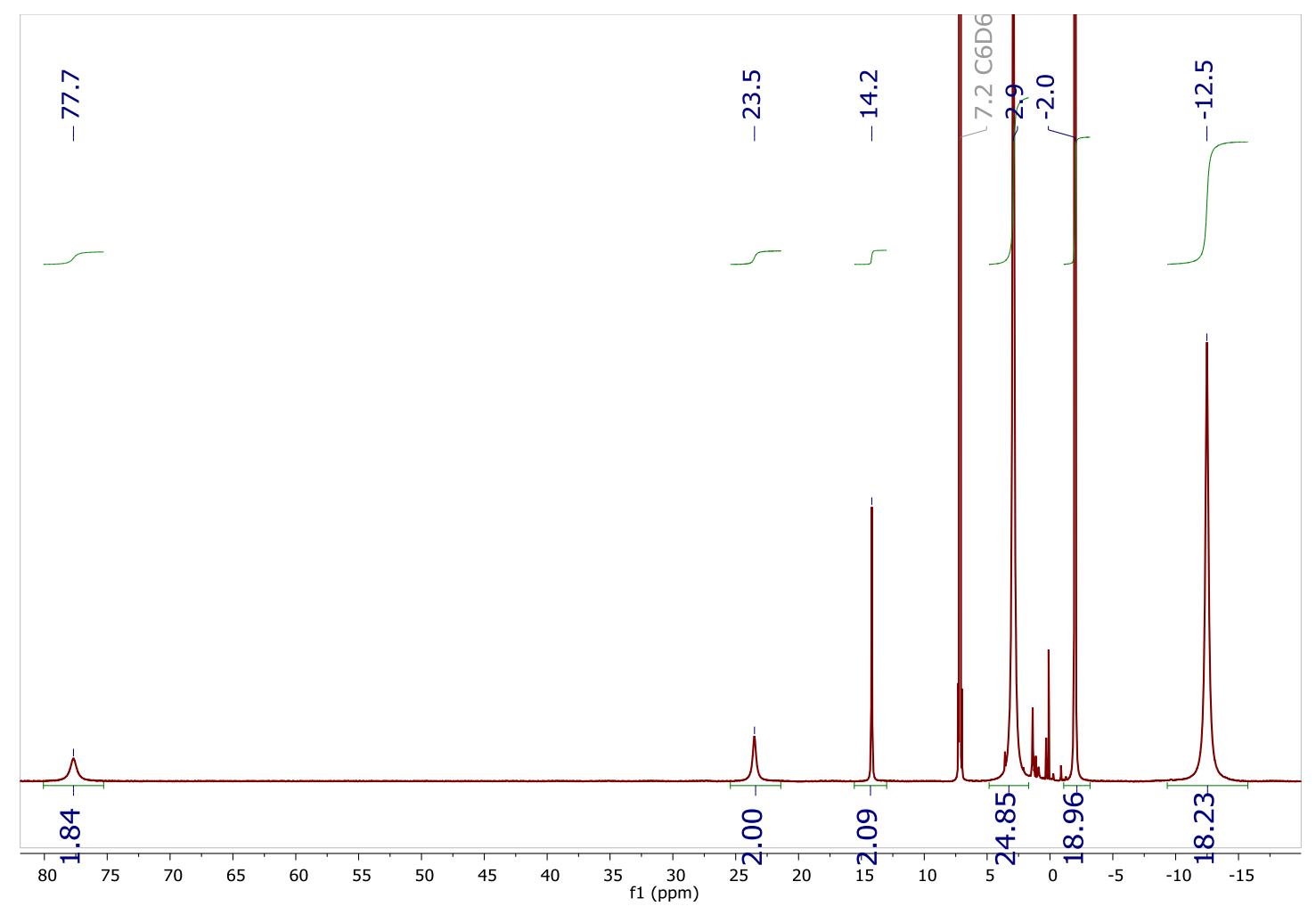

Figure S24. ${ }^{1} \mathrm{H}$ NMR spectrum of 10 in $\mathrm{C}_{6} \mathrm{D}_{6}$ at $25^{\circ} \mathrm{C}$.

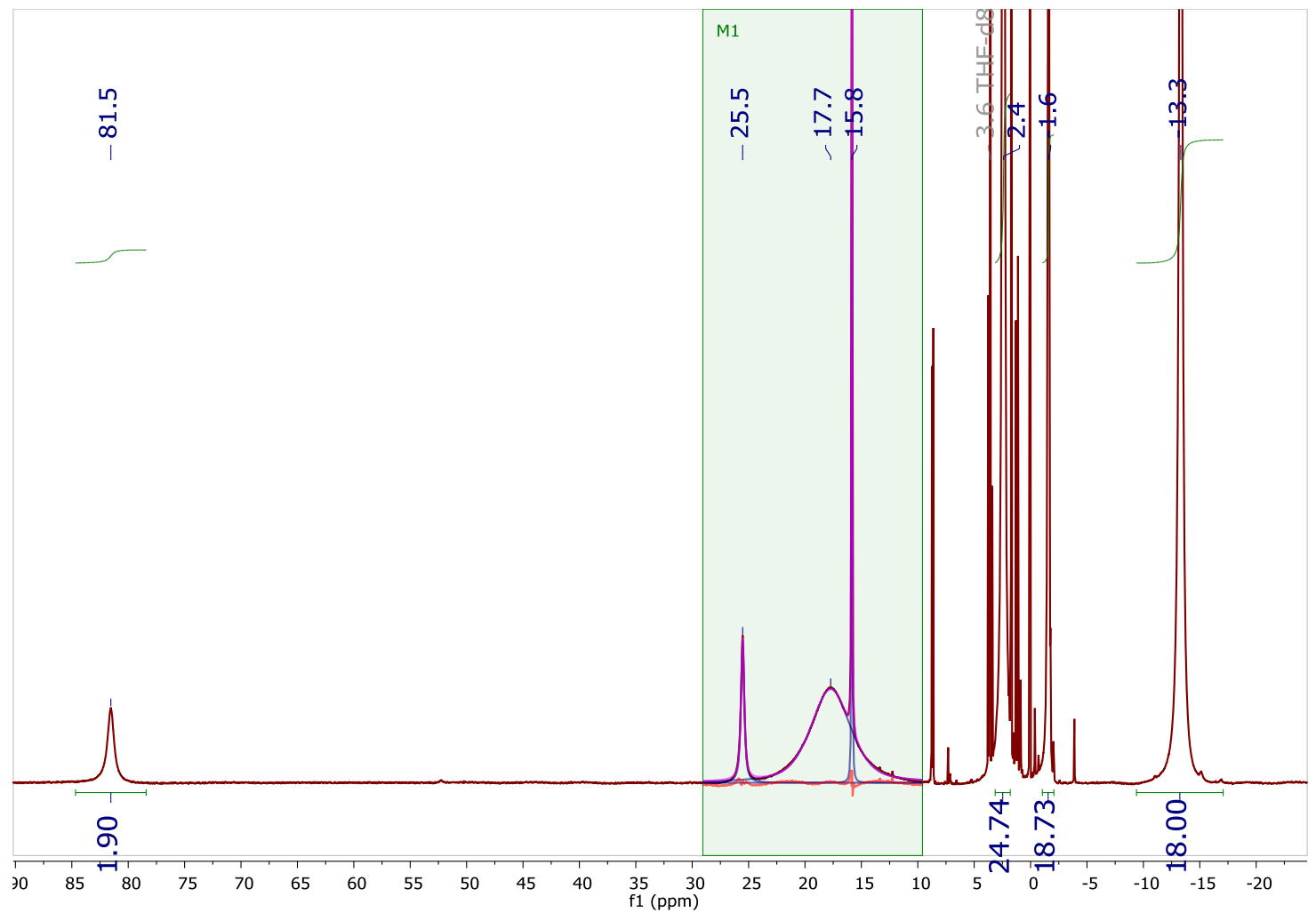

Figure S25. ${ }^{1} \mathrm{H}$ NMR spectrum of 10 in THF- $d_{8}$ at $25^{\circ} \mathrm{C}$. The three peaks between 10 and 30 ppm were deconvoluted using the line fitting feature in MesReNova. 


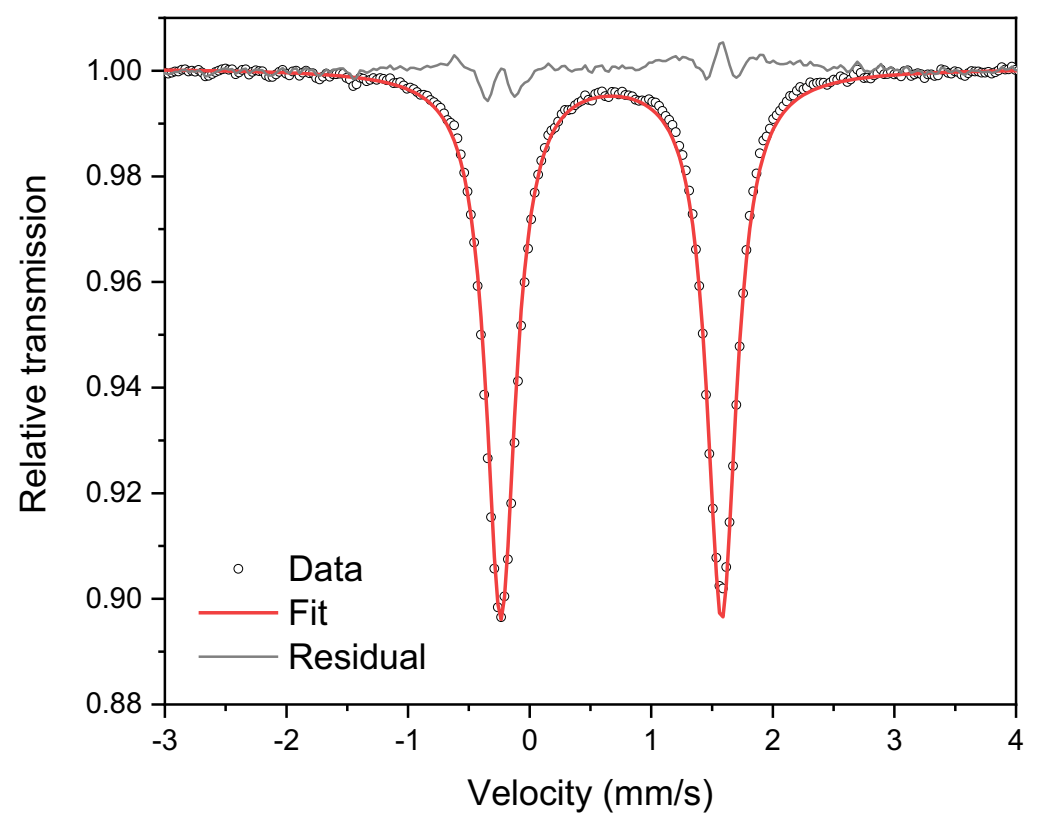

Figure S26. Mössbauer spectrum of solid 10 recorded at $80 \mathrm{~K}$. Fit parameters: $\delta=0.67 \mathrm{~mm} / \mathrm{s},\left|\Delta E_{\mathrm{Q}}\right|=1.82$ $\mathrm{mm} / \mathrm{s}, \Gamma_{\mathrm{L}}=\Gamma_{\mathrm{R}}=0.30 \mathrm{~mm} / \mathrm{s}$.
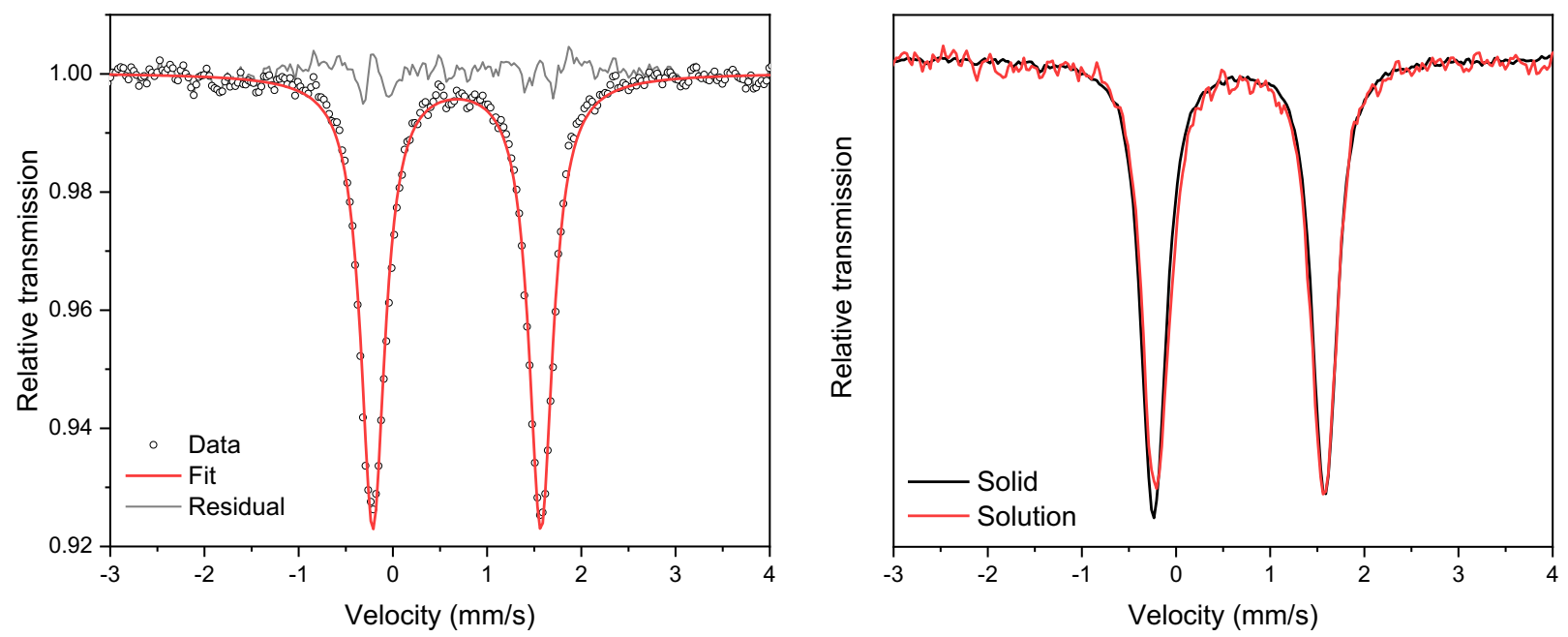

Figure S27. (Left): Mössbauer spectrum of $8.3 \mathrm{mM} 10 \mathrm{in} \mathrm{THF} \mathrm{recorded} \mathrm{at} 80 \mathrm{~K}$. Fit parameters: $\delta=0.68$ $\mathrm{mm} / \mathrm{s},\left|\Delta E_{\mathrm{Q}}\right|=1.78 \mathrm{~mm} / \mathrm{s}, \Gamma_{\mathrm{L}}=\Gamma_{\mathrm{R}}=0.31 \mathrm{~mm} / \mathrm{s}$. (Right): Overlay of data for solid (black) and solution (red) samples. 


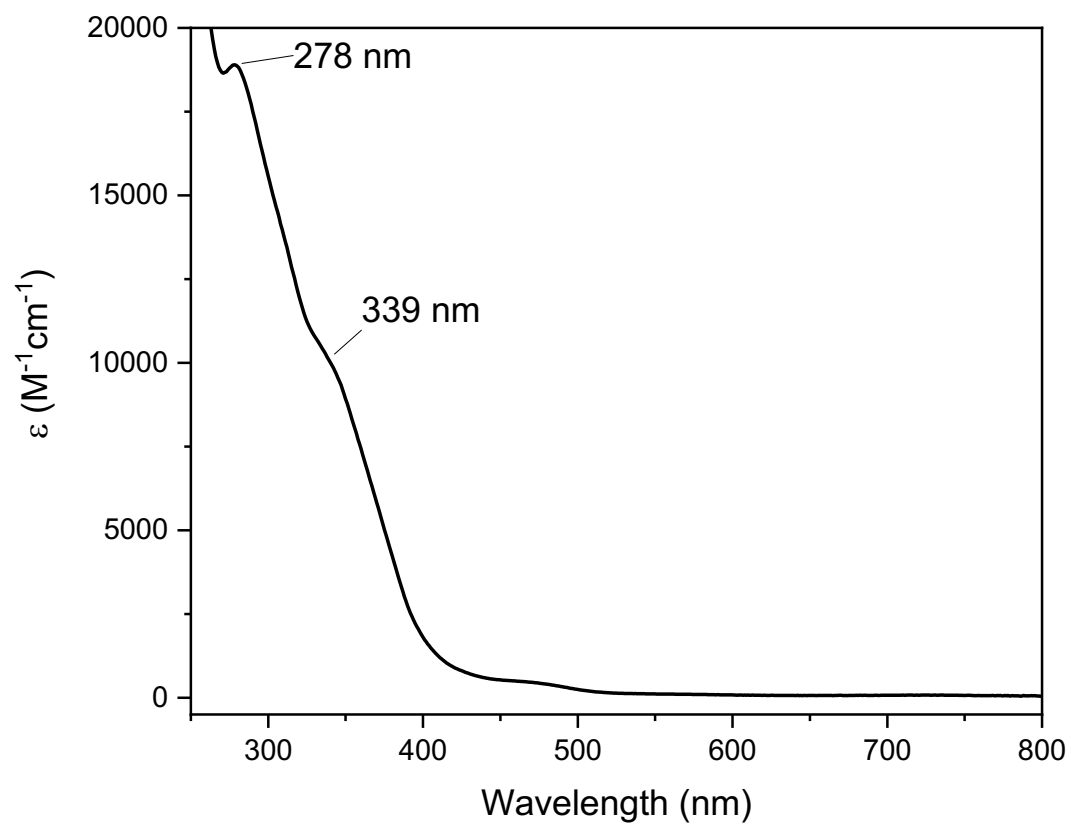

Figure S28. UV-Visible spectrum of 10 at room temperature in THF.

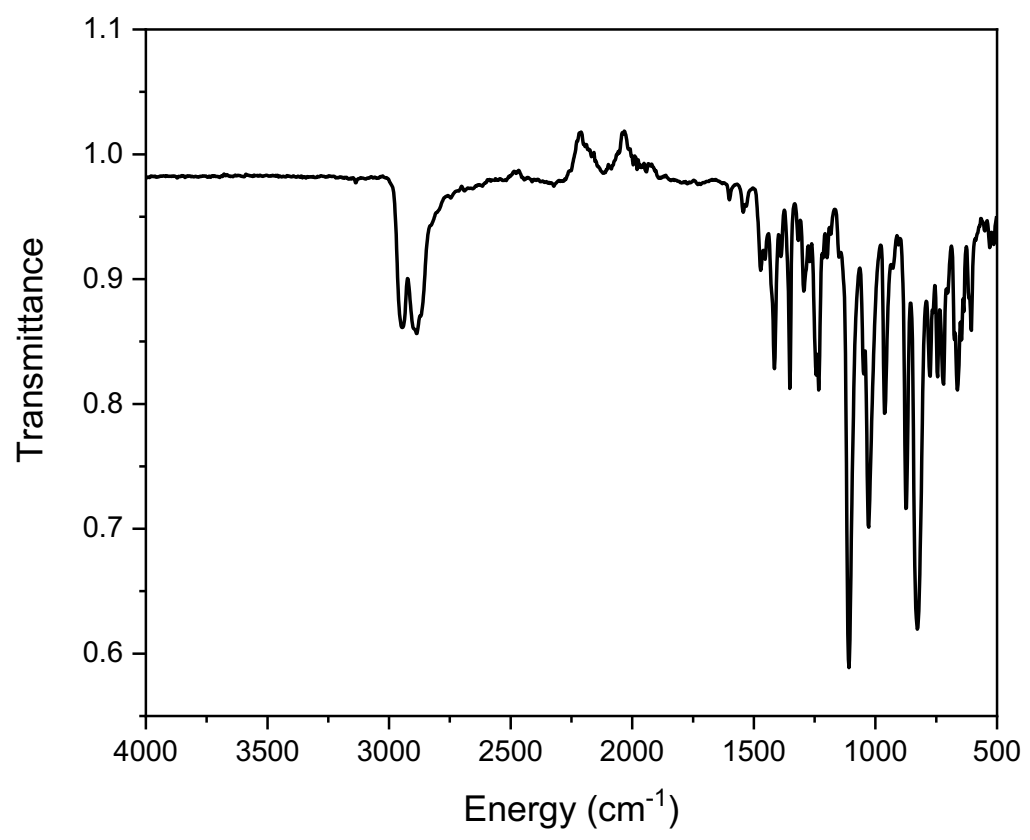

Figure S29. FT-IR spectrum of solid 10. 


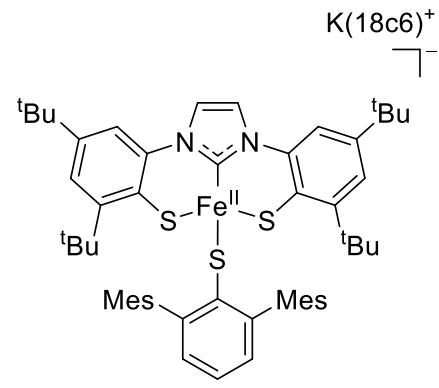

Synthesis of 11 . A $50.2 \mathrm{mg}(48.9 \mu \mathrm{mol})$ portion of 10 was combined with

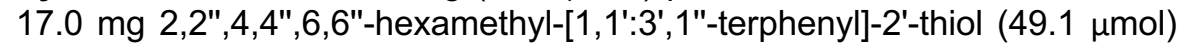
in $3 \mathrm{~mL}$ of THF. After 1.5 hours at room temperature, the solvent was removed under vacuum and the solid material was triturated 4 times with 3 $\mathrm{mL}$ of diethyl ether to remove a brown impurity. The remaining solid was dissolved in THF and filtered through Celite. The solvent was removed from the filtrate, and the material was redissolved in $2 \mathrm{~mL}$ of THF and layered with $15 \mathrm{~mL}$ of hexanes. After 2 days at $-40^{\circ} \mathrm{C}$, a yellow crystalline solid formed. The mother liquor was decanted off and the crystals were washed with $3 \times 2$ $\mathrm{mL}$ of hexanes, then dried under vacuum yielding $49.1 \mathrm{mg}$ of yellow powder. This material contains residual hexanes (1 equiv) based on ${ }^{1} \mathrm{H}$ NMR spectroscopy; the corrected yield is $45.8 \mathrm{mg}(77 \%$ yield $)$.

${ }^{1} \mathrm{H}$ NMR (THF-d $\left., 400 \mathrm{MHz}, 25^{\circ} \mathrm{C}\right): 71.0(2 \mathrm{H}), 28.7(2 \mathrm{H}), 23.3(2 \mathrm{H}),-0.1(18 \mathrm{H}),-3.9(24 \mathrm{H}),-6.7(18 \mathrm{H})$, $-23.9(1 \mathrm{H}) \mathrm{ppm}$. Note: most of the peaks for the monothiolate ligand are broadened by exchange at room temperature but can be observed upon cooling to $-40^{\circ} \mathrm{C}$.

${ }^{1} \mathrm{H}$ NMR (THF-d8, $\left.500 \mathrm{MHz},-40{ }^{\circ} \mathrm{C}\right): 94.5(2 \mathrm{H}), 67.7(1 \mathrm{H}), 35.8(2 \mathrm{H}), 35.0(6 \mathrm{H}), 30.5(1 \mathrm{H}), 26.6(2 \mathrm{H}), 23.2$ $(2 \mathrm{H}), 11.6(3 \mathrm{H}),-0.5(18 \mathrm{H}),-5.8(24 \mathrm{H}),-9.0(3 \mathrm{H}),-11.1(18 \mathrm{H}),-23.7(6 \mathrm{H}),-32.8(1 \mathrm{H}),-34.7(2 \mathrm{H}) \mathrm{ppm}$.

Evans moment $\mu_{\text {eff }}\left(\mathrm{THF}-d_{8}, 25^{\circ} \mathrm{C}\right): 5.0(1) \mu \mathrm{B}$.

Anal. Calc. for $\mathrm{C}_{73} \mathrm{H}_{105} \mathrm{~N}_{2} \mathrm{~S}_{3} \mathrm{KO}_{6} \mathrm{Fe}$ (11•hexane): C, 67.56, H, 8.16, N, 2.16 Found: C, 67.22, H, 8.10, N, 2.28 (The presence of one equivalent of hexane was confirmed by integration of the ${ }^{1} \mathrm{H}$ NMR spectrum for this batch of material.)

Mössbauer (solid-state): $\delta=0.68 \mathrm{~mm} / \mathrm{s},\left|\Delta E_{\mathrm{Q}}\right|=1.76 \mathrm{~mm} / \mathrm{s}, \Gamma_{\mathrm{L}}=\Gamma_{\mathrm{R}}=0.33 \mathrm{~mm} / \mathrm{s}$.

Mössbauer (10 mM in THF): $\delta=0.67 \mathrm{~mm} / \mathrm{s},\left|\Delta E_{\mathrm{Q}}\right|=2.07 \mathrm{~mm} / \mathrm{s}, \Gamma_{\mathrm{L}}=\Gamma_{\mathrm{R}}=0.42 \mathrm{~mm} / \mathrm{s}$.

UV-Vis (THF): $294 \mathrm{~nm}\left(\varepsilon=21,000 \mathrm{M}^{-1} \mathrm{~cm}^{-1}\right)$.

FT-IR ( $\left.\mathrm{cm}^{-1}\right): 2950(\mathrm{~m}), 2900(\mathrm{~m}), 2881(\mathrm{~m}), 2855(\mathrm{~m}), 1611(\mathrm{w}), 1599(\mathrm{w}), 1572(\mathrm{w}), 1542(\mathrm{w}), 1517(\mathrm{w})$, $1452(\mathrm{~m}), 1415(\mathrm{~m}), 1385(\mathrm{~m}), 1350(\mathrm{~m}), 1323(\mathrm{w}), 1291(\mathrm{w}), 1266(\mathrm{w}), 1248(\mathrm{~m}), 1215(\mathrm{w}), 1197(\mathrm{w}), 1183$ (w), $1148(\mathrm{w}), 1103(\mathrm{~s}), 1048(\mathrm{~s}), 960(\mathrm{~s}), 901(\mathrm{w}), 873(\mathrm{~m}), 834(\mathrm{~s}), 791(\mathrm{w}), 775(\mathrm{w}), 761(\mathrm{w}), 740(\mathrm{~m}), 734$ $(\mathrm{m}), 712(\mathrm{~m}), 675(\mathrm{~m}), 646(\mathrm{w}), 638(\mathrm{w}), 606(\mathrm{w}), 583(\mathrm{w}), 575(\mathrm{w}), 549(\mathrm{w}), 526(\mathrm{w}), 512(\mathrm{w})$. 


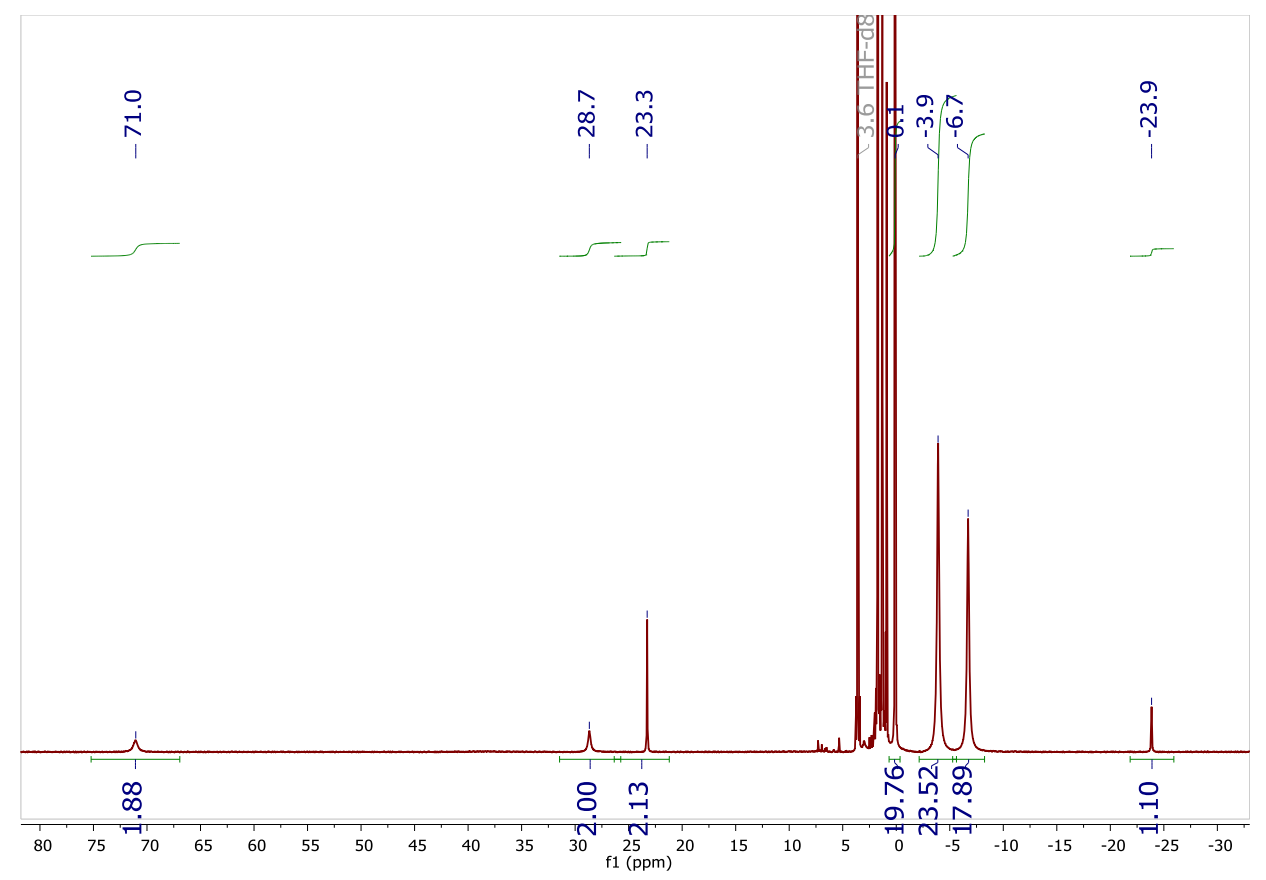

Figure S30. ${ }^{1} \mathrm{H}$ NMR spectrum of 11 at $25^{\circ} \mathrm{C}$ in THF- $d_{8}$.

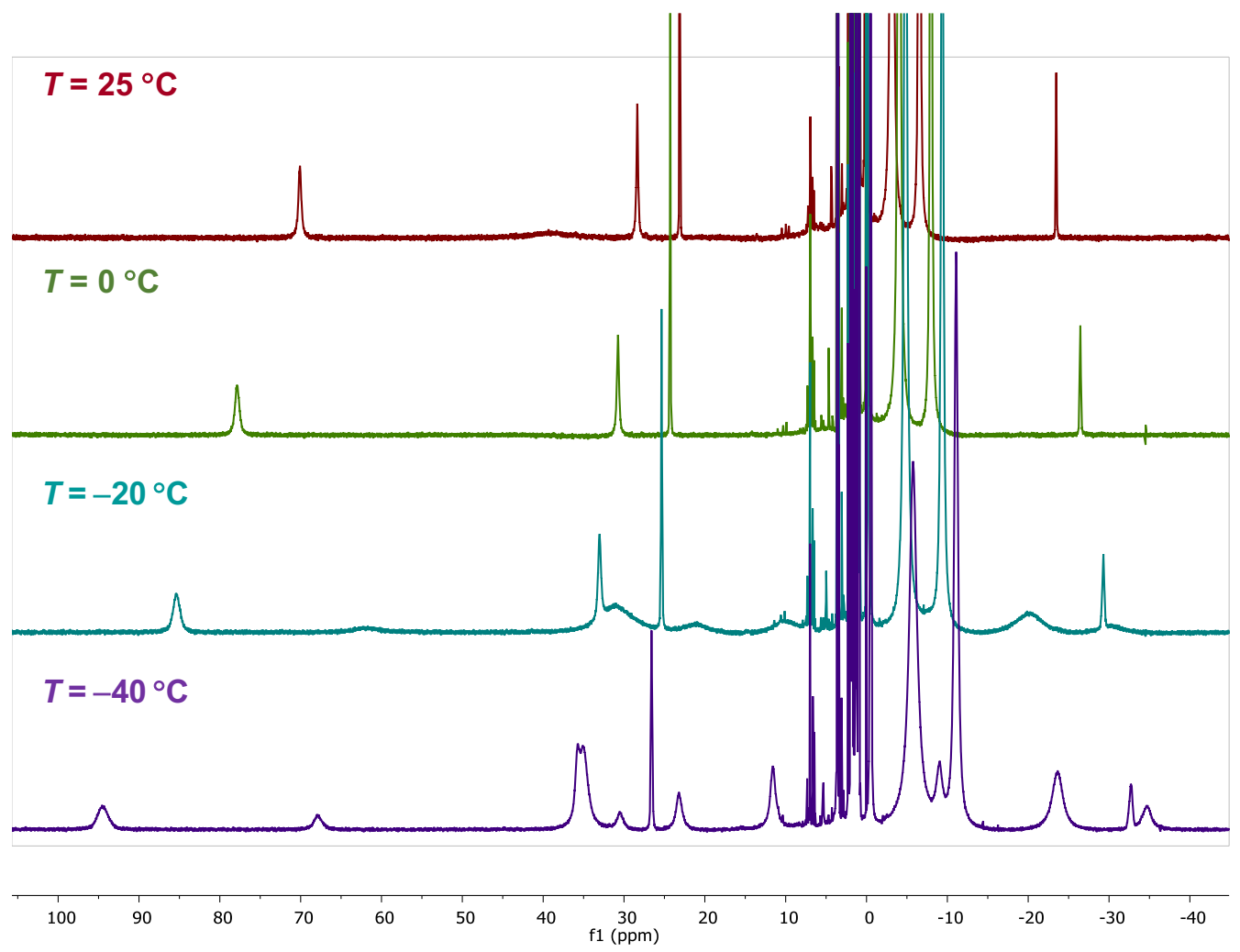

Figure S31. Variable-temperature ${ }^{1} \mathrm{H}$ NMR spectra of 11 in THF- $d_{8}$ showing the decoalescence of signals for the monothiolate ligand upon cooling to $-40^{\circ} \mathrm{C}$. 


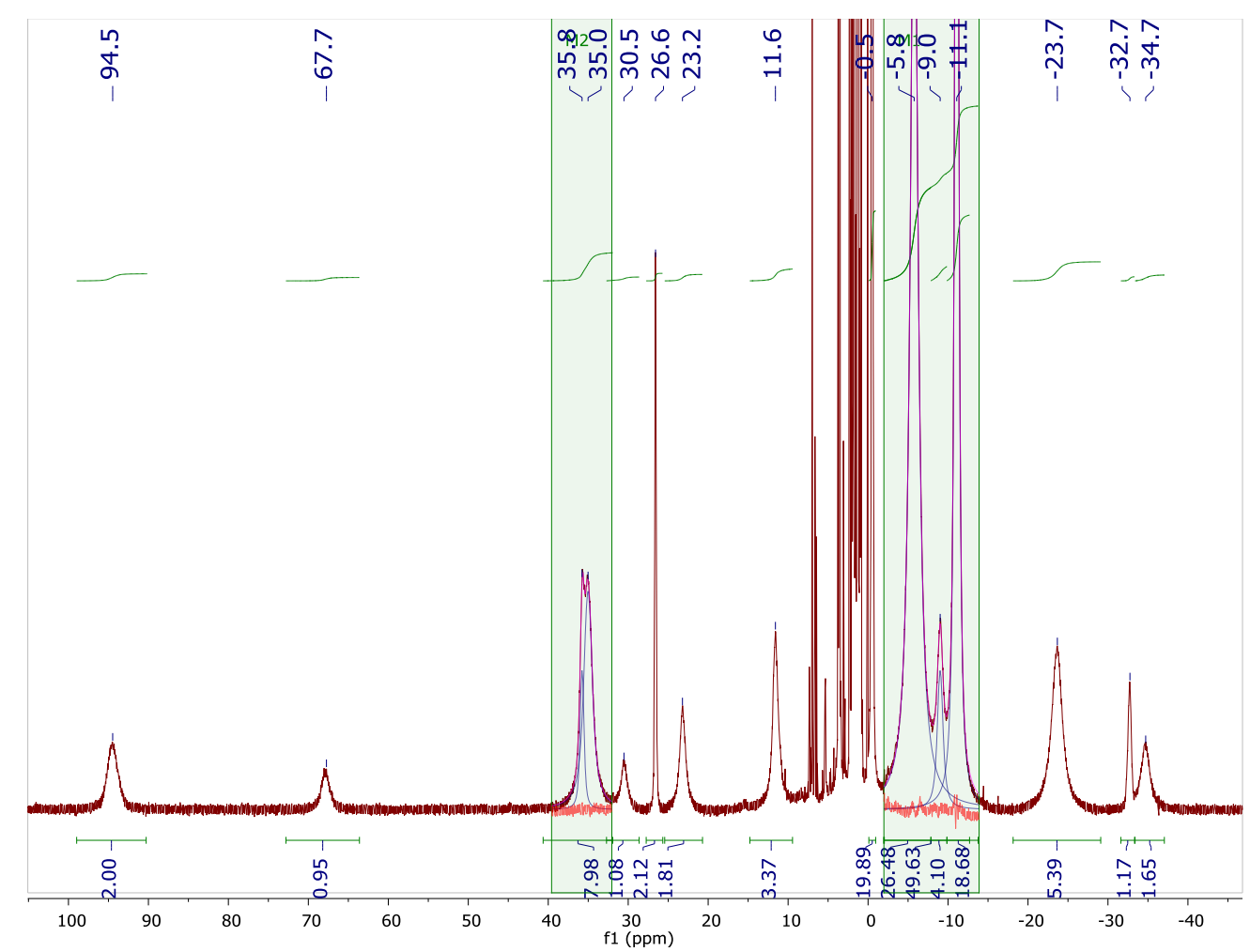

Figure S32. Analysis of the ${ }^{1} \mathrm{H}$ NMR spectrum of 11 in THF- $d_{8}$ at $-40{ }^{\circ} \mathrm{C}$. Overlapping signals were deconvoluted using the line fitting feature in MesReNova. 


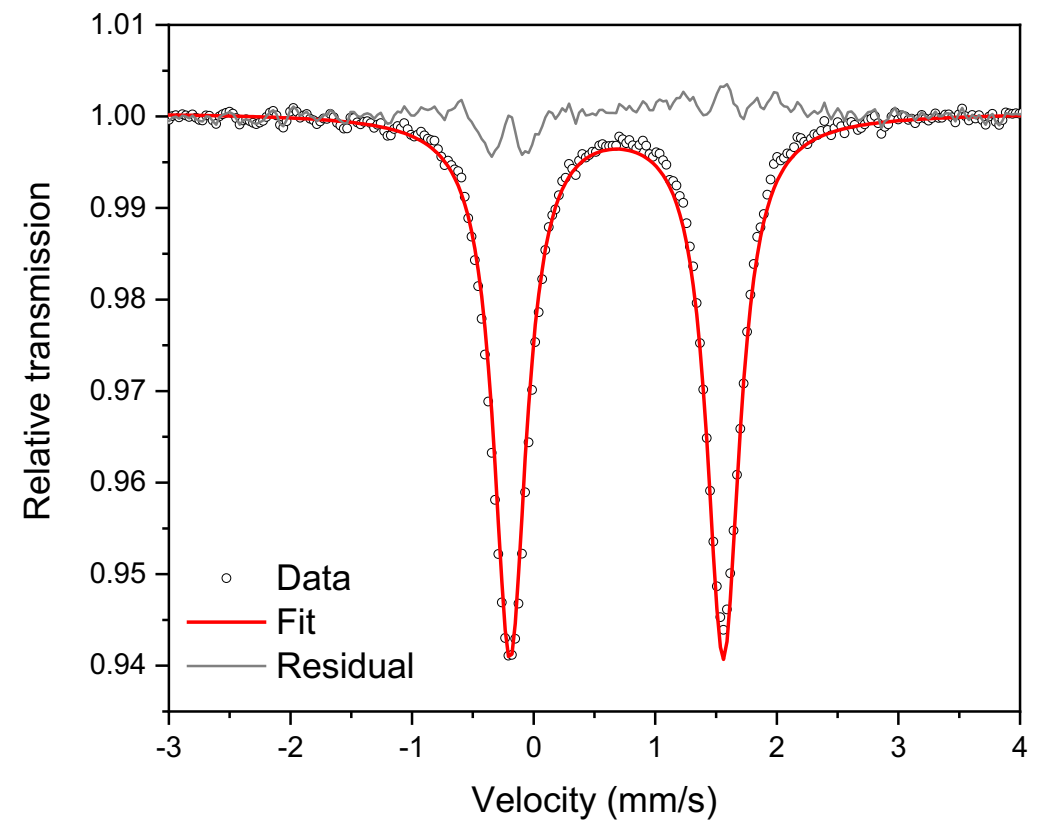

Figure S33. Mössbauer spectrum of solid 11. Fit parameters: $\delta=0.68 \mathrm{~mm} / \mathrm{s},\left|\Delta E_{\mathrm{Q}}\right|=1.76 \mathrm{~mm} / \mathrm{s}$, $\Gamma_{\mathrm{L}}=\Gamma_{\mathrm{R}}=0.33 \mathrm{~mm} / \mathrm{s}$.
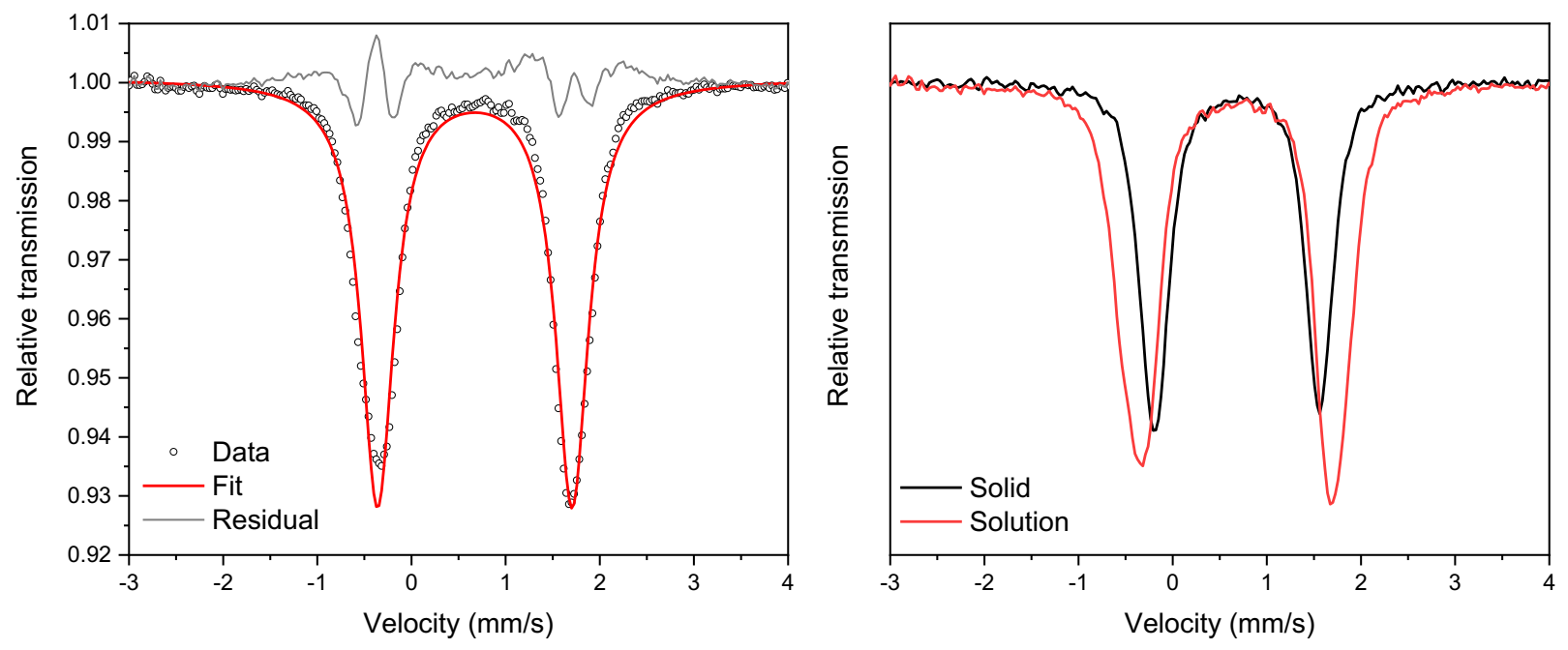

Figure S34. (Left): Mössbauer spectrum of a frozen $10 \mathrm{mM}$ solution of $11 \mathrm{in} \mathrm{THF}$. Fit parameters: $\delta=0.67$ $\mathrm{mm} / \mathrm{s},\left|\Delta E_{\mathrm{Q}}\right|=2.07 \mathrm{~mm} / \mathrm{s}, \Gamma \mathrm{L}=\Gamma_{\mathrm{R}}=0.42 \mathrm{~mm} / \mathrm{s}$ (Right): Overlay of data for solid (black) and solution (red) samples. 


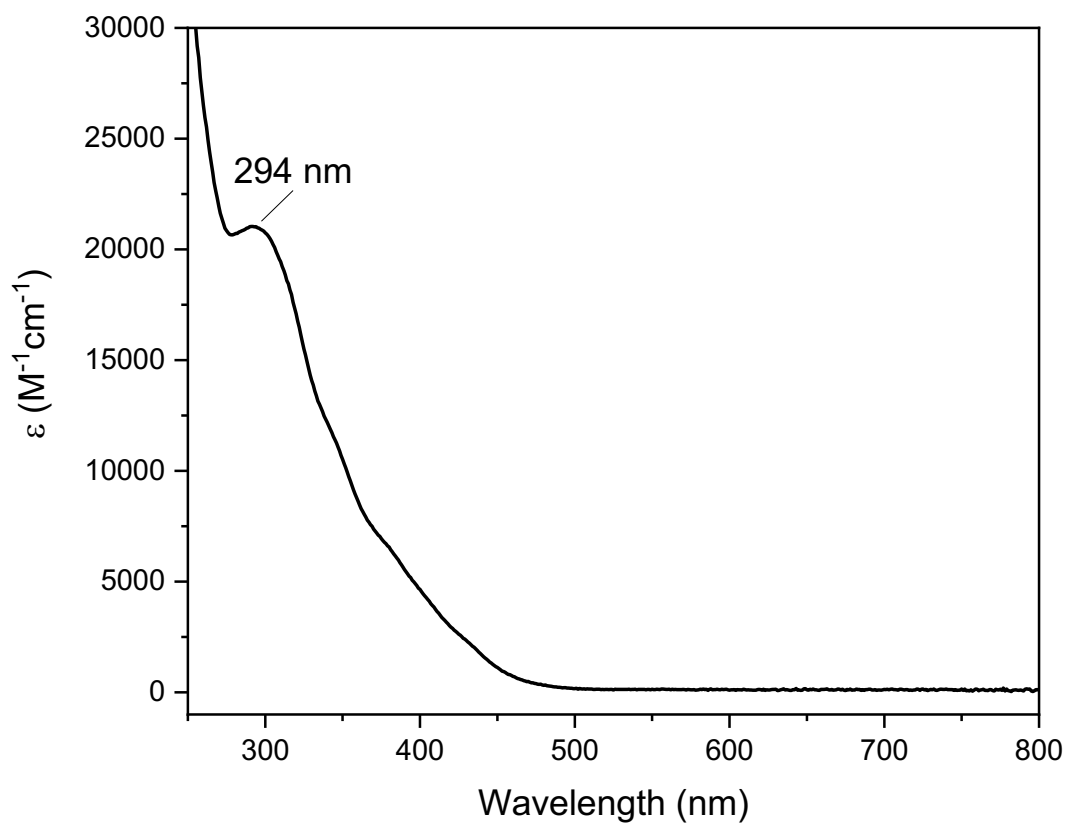

Figure S35. UV-Visible spectrum of 11 in THF at room temperature.

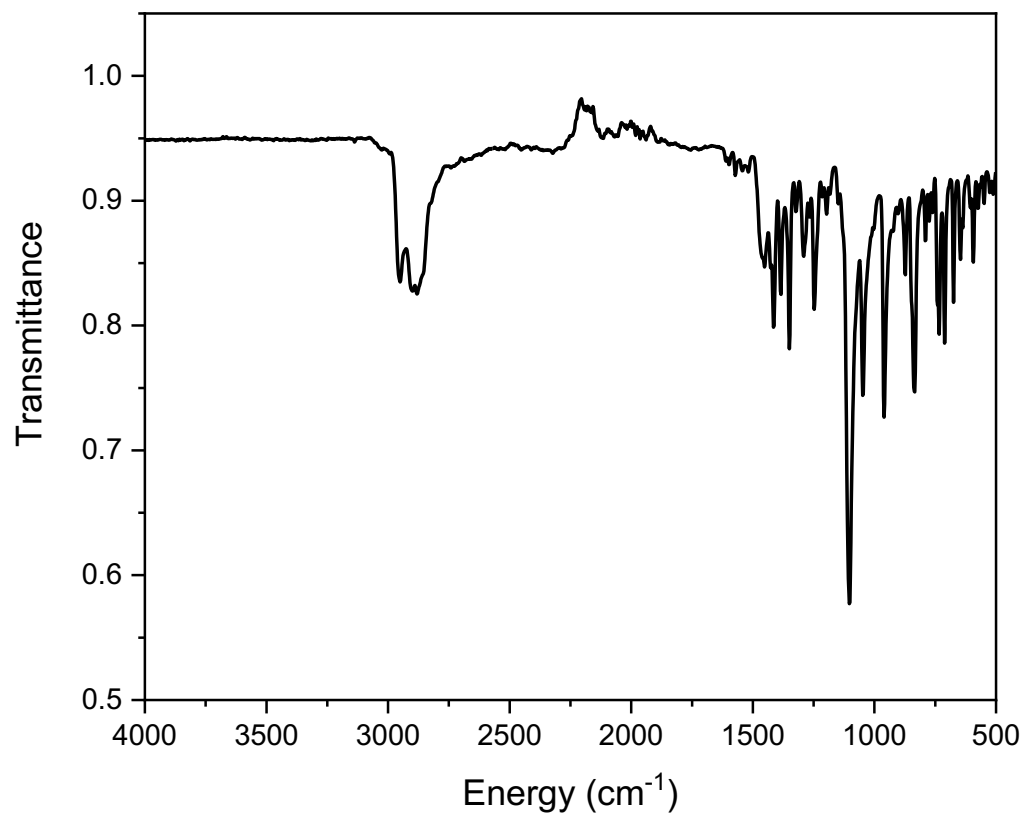

Figure S36. FT-IR spectrum of solid 11. 


\section{Note on purity of 12 and 13}

Based on ${ }^{1} \mathrm{H}$ NMR spectroscopy, isolated 12 and 13 typically contain $5-10 \%$ of a decomposition product that forms during workup. All attempts to remove this impurity via recrystallization resulted in further decomposition. Consequently, we were unable to obtain satisfactory elemental analyses for these complexes.

We determined that the decomposed species forms via reaction with trace water by spiking an NMR sample of 13 generated in situ with 0.1 equiv of $\mathrm{H}_{2} \mathrm{O}$ (Figure S37). This results in formation of the same species that is present as a minor impurity in isolated 12 and 13 (Figures S39 and S43).

In order to model the presence of this species in Mössbauer samples of 12 and 13, 1.1 equiv of $\mathrm{H}_{2} \mathrm{O}$ was added to a benzene solution of 10 (enriched with $20 \%{ }^{57} \mathrm{Fe}$ ). This resulted in precipitation of a yellow solid which was collected by filtration and analyzed by Mössbauer spectroscopy. The Mössbauer spectrum of this species (Figure S34) contains a single quadrupole doublet $\left(\delta=0.71 \mathrm{~mm} / \mathrm{s},\left|\Delta E_{\mathrm{Q}}\right|=1.42 \mathrm{~mm} / \mathrm{s}, \Gamma \mathrm{L}=\Gamma_{\mathrm{R}}\right.$ $=0.33 \mathrm{~mm} / \mathrm{s}$ ).

Due to its extreme air sensitivity and poor solubility in common organic solvents, we were unable to purify and fully characterize the product from hydrolysis. Based on the similarity of its ${ }^{1} \mathrm{H}$ NMR and Mössbauer spectra to those of 10-13, it could be a hydroxide or $\mu$-oxo complex that is structurally analogous to 10-13.

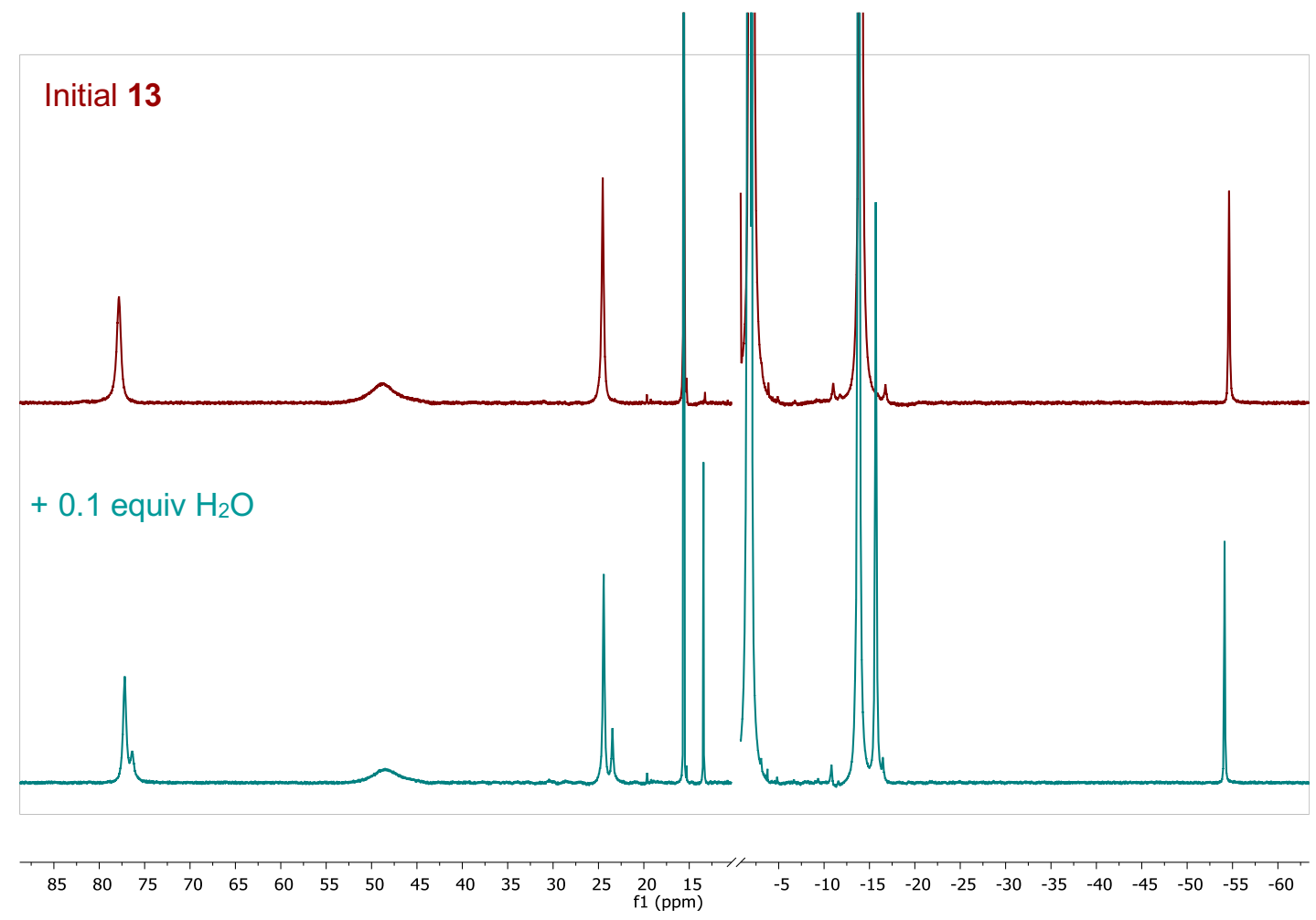

Figure S37. ${ }^{1} \mathrm{H}$ NMR spectra (4:1 protio-THF: $\left.\mathrm{C}_{6} \mathrm{D}_{6}\right)$ of in situ-generated $13(18 \mathrm{mM})$ before (top) and after (bottom) addition of 0.1 equiv of $\mathrm{H}_{2} \mathrm{O}$. The new peaks that appear slightly upfield of the major species correspond to the hydrolyzed product. The wet1D pulse sequence was used for suppression of the THF signal and the diamagnetic region is omitted for clarity due to the presence of artifacts from the solvent suppression. 


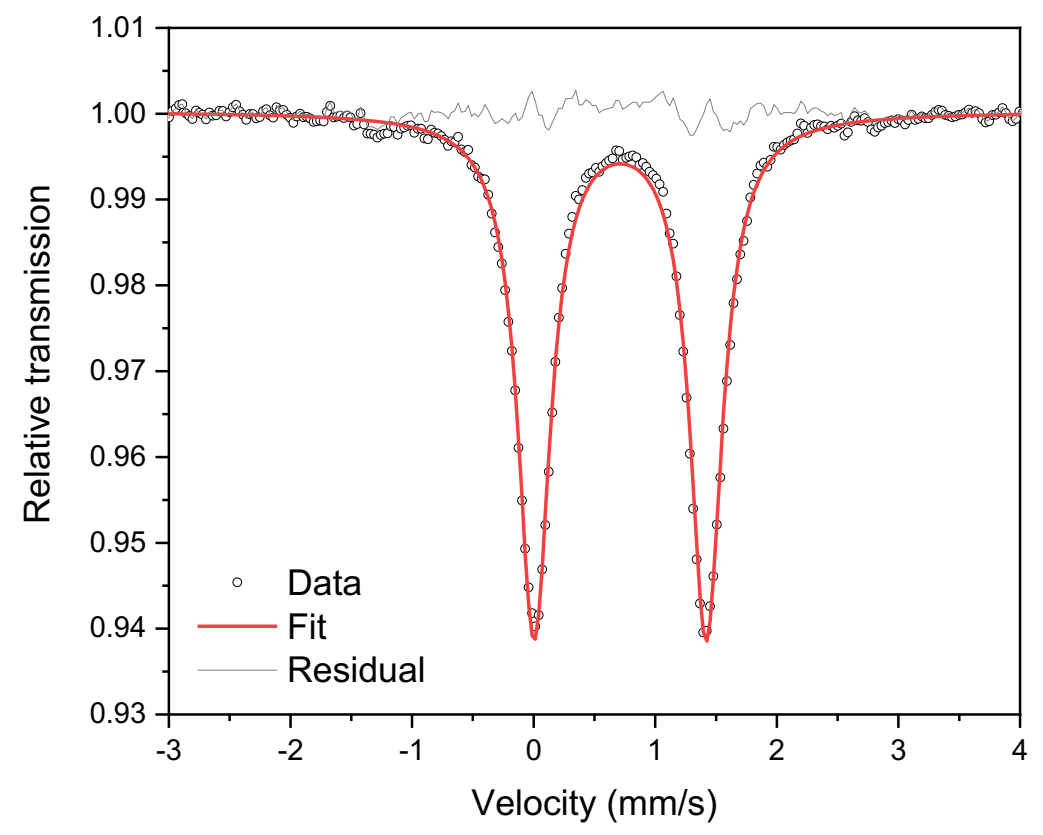

Figure S38. Mössbauer spectrum (solid state) of hydrolysis product generated by addition of 1.1 equiv of $\mathrm{H}_{2} \mathrm{O}$ to 10 in benzene. Fit parameters: $\delta=0.71 \mathrm{~mm} / \mathrm{s},\left|\Delta \mathrm{EQ}_{\mathrm{Q}}\right|=1.42 \mathrm{~mm} / \mathrm{s}, \Gamma \mathrm{L}=\Gamma_{\mathrm{R}}=0.33 \mathrm{~mm} / \mathrm{s}$. 
$\mathrm{K}(18 \mathrm{c} 6)^{+} \quad$ Synthesis of 12 . A $50.3 \mathrm{mg}(49.0 \mu \mathrm{mol})$ portion of 10 was dissolved in 2.5 $\mathrm{mL}$ of benzene and $5.0 \mu \mathrm{L}(51 \mu \mathrm{mol}, 1.04$ equiv) of phenylhydrazine was added. (We note that control of stoichiometry is important in this reaction because 12 decomposes more rapidly in the presence of excess phenylhydrazine). The solution was stirred for 2 hours, during which time a slow color change from yellow to red occurred. The solvent was removed under vacuum, and the resulting orange solid was washed with $10 \mathrm{~mL}$ of diethyl ether in $2 \mathrm{~mL}$ portions. The solid was dissolved in $2 \mathrm{~mL}$ of THF and layered with $10 \mathrm{~mL}$ of diethyl ether. After $36 \mathrm{~h}$ at $-40^{\circ} \mathrm{C}$, red crystals formed. The mother liquor was decanted and the crystals were washed with $3 \times 1 \mathrm{~mL}$ of diethyl ether, then crushed and dried under vacuum, yielding $37.1 \mathrm{mg}$ of an orange powder. This material contains residual diethyl ether (1 equiv) as well as 0.03 equivalents of hydrolyzed material based on ${ }^{1} \mathrm{H}$ NMR spectroscopy (see discussion above). The corrected yield is $33 \mathrm{mg}$ ( $70 \%$ yield).

${ }^{1} \mathrm{H}$ NMR (THF-d8, $\left.500 \mathrm{MHz}\right): 166.6(1 \mathrm{H}), 75.7(2 \mathrm{H}), 60.6(1 \mathrm{H}), 25.8(1 \mathrm{H}), 23.9(2 \mathrm{H}), 16.7(2 \mathrm{H}), 0.7(24 \mathrm{H})$, $-1.6(18 \mathrm{H}),-13.1(18 \mathrm{H}),-59.7(1 \mathrm{H}),-78.0\left(1 \mathrm{H}^{*}\right) \mathrm{ppm}$. *The integrated intensity of this peak is lower than expected, presumably due to severe line broadening.

Evans $\mu_{\text {eff }}\left(\right.$ THF- $\left.d_{8}, 25^{\circ} \mathrm{C}\right): 5.0(1) \mu_{\mathrm{B}}$.

Satisfactory elemental analysis for this compound could not be obtained due to its extreme moisture sensitivity (see discussion above).

Mössbauer (solid state): $\delta=0.65 \mathrm{~mm} / \mathrm{s},\left|\Delta E_{\mathrm{Q}}\right|=1.60 \mathrm{~mm} / \mathrm{s}, \Gamma_{\mathrm{L}}=\Gamma_{\mathrm{R}}=0.32 \mathrm{~mm} / \mathrm{s}$.

UV-Vis (THF): $278 \mathrm{~nm}\left(\varepsilon=24,000 \mathrm{M}^{-1} \mathrm{~cm}^{-1}\right) 335 \mathrm{~nm}\left(\mathrm{sh}, \varepsilon=15,000 \mathrm{M}^{-1} \mathrm{~cm}^{-1}\right)$.

FT-IR (cm $\left.{ }^{-1}\right): 3305(\mathrm{w}), 3108(\mathrm{w}), 3075(\mathrm{w}), 3042(\mathrm{w}), 2949(\mathrm{~m}), 2900(\mathrm{~m}), 2881(\mathrm{~m}), 2867(\mathrm{~m}), 1603(\mathrm{w})$, $1590(\mathrm{w}), 1576(\mathrm{w}), 1546(\mathrm{w}), 1487(\mathrm{~m}), 1466(\mathrm{~m}), 1413(\mathrm{~m}), 1390(\mathrm{w}), 1350(\mathrm{~s}), 1285(\mathrm{~m}), 1248(\mathrm{~m}), 1197$ $(w), 1175(w), 1150(w), 1105(s), 1048(m), 1020(w), 981(w), 960(m), 922(w), 905(w), 877(m), 840(s)$, $761(w), 740(m), 728(m), 691(m), 675(w), 646(w), 634(m), 606(w), 514(w)$. 


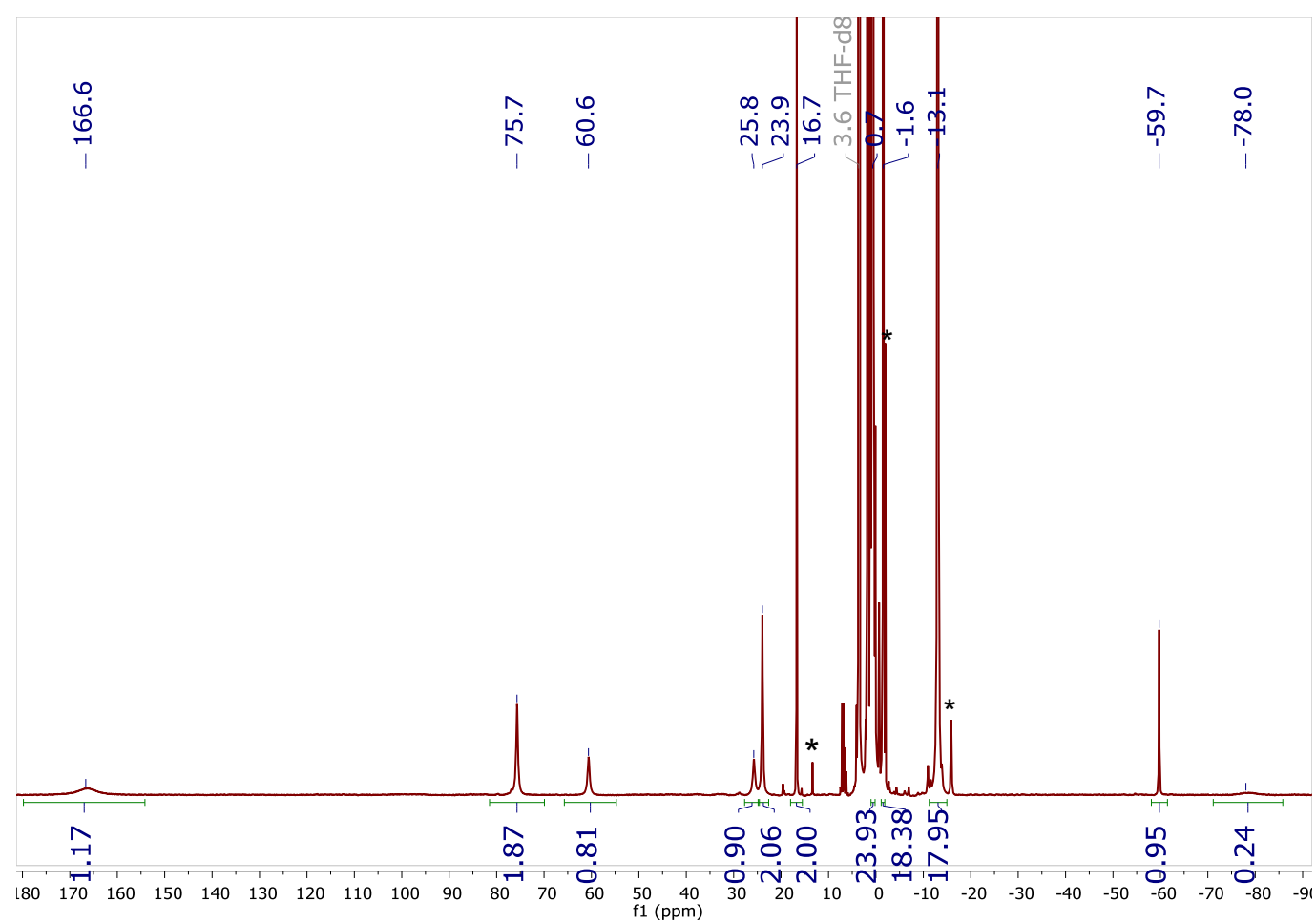

Figure S39. ${ }^{1} \mathrm{H}$ NMR spectrum $\left(\mathrm{THF}-\mathrm{d}_{8}, 500 \mathrm{MHz}\right.$ ) of 12. The peaks at $13.4,-2.0$, and $-15.9 \mathrm{ppm}$ marked with an asterisk correspond to hydrolyzed material (see discussion above).

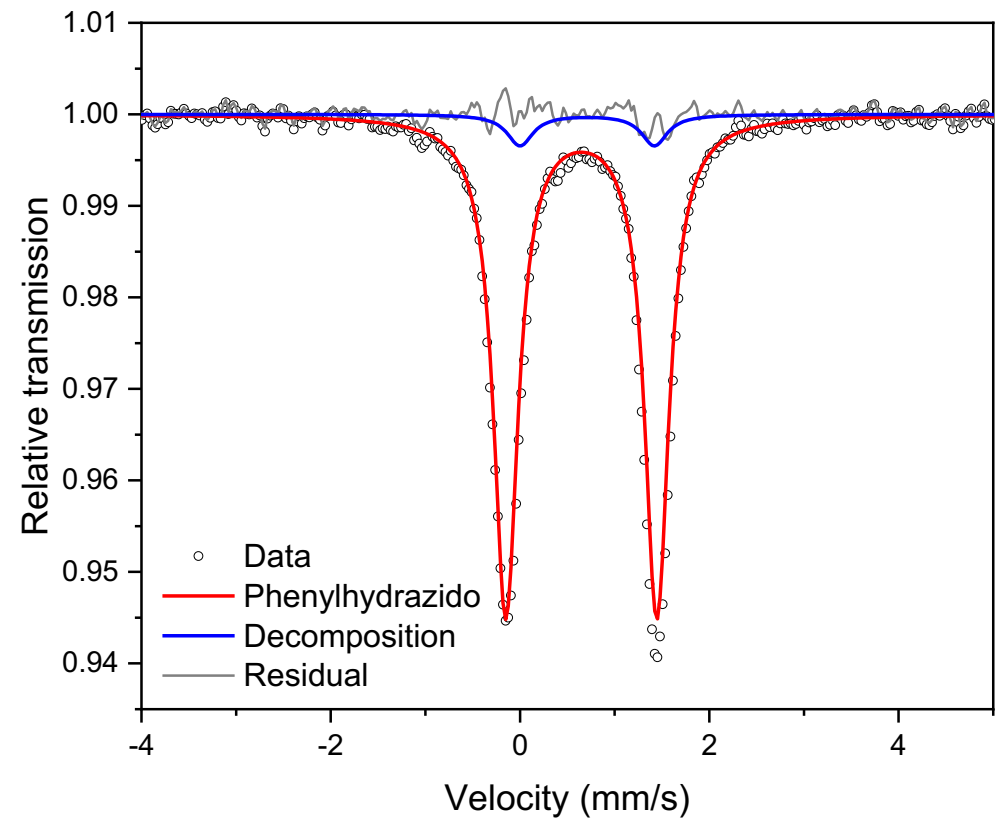

Figure S40. Solid-state Mössbauer spectrum of 12. A $6 \%$ impurity from hydrolyzed material (blue line; see discussion above) is included in the fit based on analysis of the ${ }^{1} \mathrm{H}$ NMR spectrum of this material. Fit parameters for 12: $\delta=0.65 \mathrm{~mm} / \mathrm{s},\left|\Delta E_{Q}\right|=1.60 \mathrm{~mm} / \mathrm{s}, \Gamma \mathrm{L}=\Gamma_{\mathrm{R}}=0.32 \mathrm{~mm} / \mathrm{s}$. 


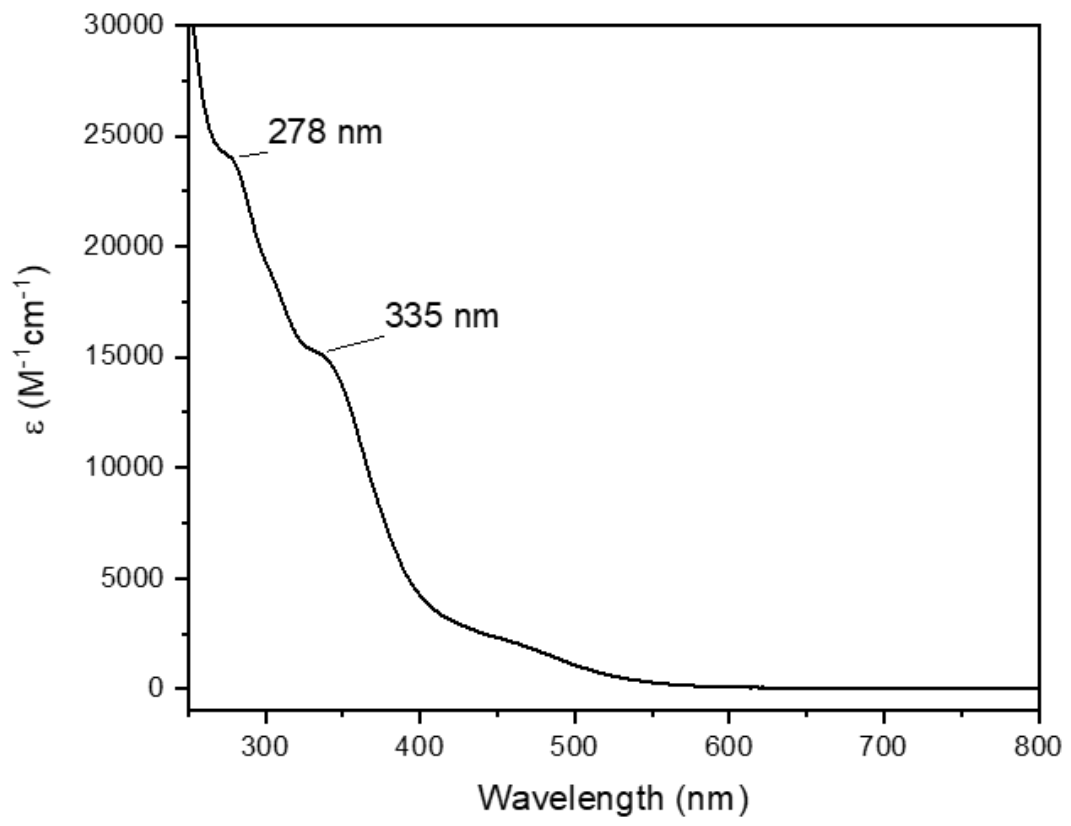

Figure S41. UV-Visible spectrum of 12 in THF.

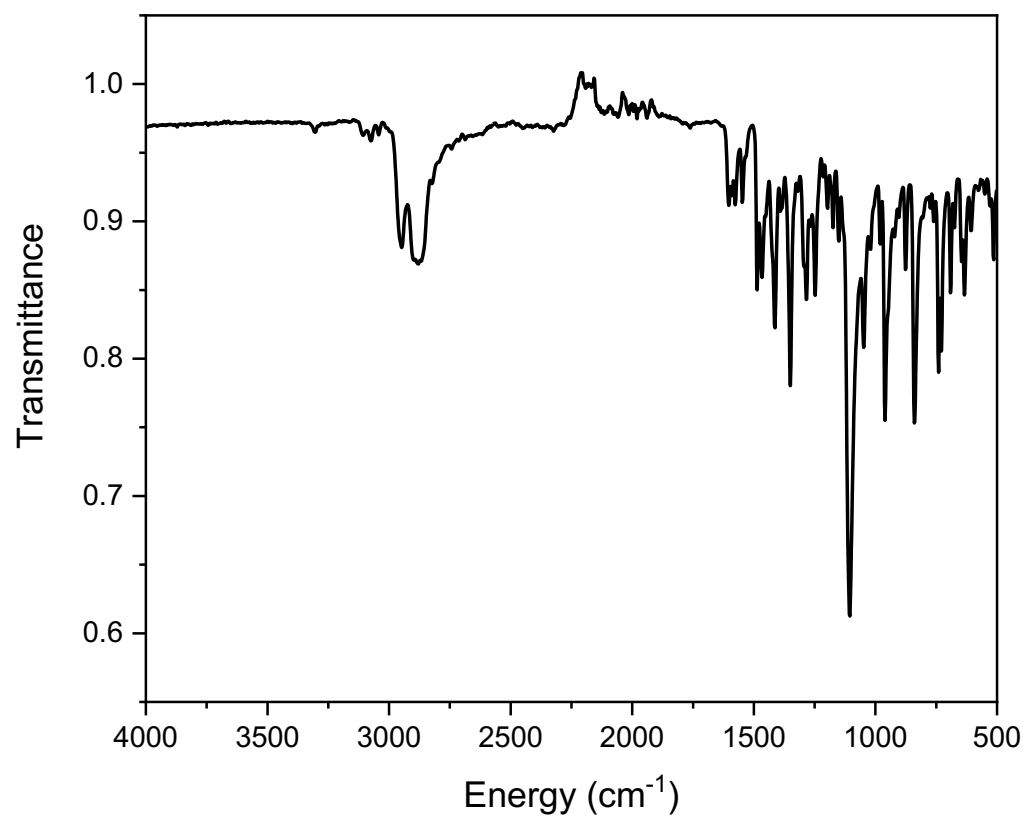

Figure S42. FT-IR spectrum of solid 12. 
$\mathrm{K}(18 \mathrm{c} 6)^{+}$Synthesis of 13 . A $50.3 \mathrm{mg}(49.0 \mu \mathrm{mol})$ portion of 10 was dissolved in 2.5 $\mathrm{mL}$ of THF in a flask equipped with a resealable Teflon plug and $85 \mu \mathrm{L}(940$<smiles>CC(C)(C)c1cc(Br)cc2c1S[Te]1(Nc3ccccc3)SN3C=CN(C3=C2)c2c(Br)cc(Br)cc21</smiles>
$\mu \mathrm{mol}, 19$ equiv) of aniline was added. The flask was sealed and heated at 65 ${ }^{\circ} \mathrm{C}$ for $3 \mathrm{~h}$. The solvent was removed under vacuum and the resulting solid was washed with $10 \mathrm{~mL}$ of diethyl ether in $2 \mathrm{~mL}$ portions. The remaining solid material was dissolved in $5 \mathrm{~mL}$ of THF and filtered through Celite. The solvent was removed under vacuum and the material was redissolved in $4 \mathrm{~mL}$ of THF and layered with $15 \mathrm{~mL}$ of diethyl ether. After $36 \mathrm{~h}$, yellow crystals formed. The mother liquor was decanted off and the crystals were washed with $3 \times 2$ $\mathrm{mL}$ of diethyl ether, then crushed and dried under vacuum, yielding $37.4 \mathrm{mg}$ of a yellow powder. This material contains 0.06 equiv of hydrolyzed material (see discussion above) and 0.09 equiv of aniline. The corrected yield is $37.2 \mathrm{mg}$ (79\% yield).

${ }^{1} \mathrm{H}$ NMR (THF-d $\left.d_{8}, 400 \mathrm{MHz}\right): 78.8(2 \mathrm{H}), 49.4\left(2 \mathrm{H}^{*}\right), 24.9(2 \mathrm{H}), 15.7(2 \mathrm{H}),-1.0(24 \mathrm{H}),-1.7(18 \mathrm{H}),-14.3$ $(18 \mathrm{H}),-55.3(1 \mathrm{H}) \mathrm{ppm}$. ${ }^{*}$ The integrated intensity of this peak is lower than expected, probably due to severe line broadening.

Satisfactory elemental analysis for this compound could not be obtained due to its extreme moisture sensitivity and the presence of impurities (see discussion above).

Mössbauer (solid state): $\delta=0.67 \mathrm{~mm} / \mathrm{s},\left|\Delta E_{\mathrm{Q}}\right|=1.69 \mathrm{~mm} / \mathrm{s}, \Gamma \mathrm{L}=\Gamma_{\mathrm{R}}=0.34 \mathrm{~mm} / \mathrm{s}$.

UV-Vis (THF): $281 \mathrm{~nm}\left(\varepsilon=21,500 \mathrm{M}^{-1} \mathrm{~cm}^{-1}\right) 306 \mathrm{~nm}\left(\varepsilon=23,300 \mathrm{M}^{-1} \mathrm{~cm}^{-1}\right)$.

FT-IR (cm-1): $3162(\mathrm{w}), 3130(\mathrm{w}), 3057(\mathrm{w}), 3012(\mathrm{w}), 2948(\mathrm{~m}), 2898(\mathrm{~m}), 2879(\mathrm{~m}), 2822(\mathrm{w}), 1584(\mathrm{~m})$, $1560(\mathrm{w}), 1544(\mathrm{w}), 1484(\mathrm{~m}), 1462(\mathrm{~m}), 1413(\mathrm{~m}), 1389(\mathrm{w}), 1350(\mathrm{~s}), 1293(\mathrm{~s}), 1250(\mathrm{~m}), 1199(\mathrm{w}), 1168$ $(w), 1148(w), 1107(s), 1048(\mathrm{~m}), 1022(\mathrm{w}), 987(\mathrm{w}), 958(\mathrm{~s}), 924(\mathrm{w}), 875(\mathrm{w}), 838(\mathrm{~s}), 771(\mathrm{w}), 740(\mathrm{~s})$, $689(\mathrm{~m}), 677(\mathrm{w}), 644(\mathrm{~m}), 606(\mathrm{~m}), 577(\mathrm{~m}), 514(\mathrm{w})$. 


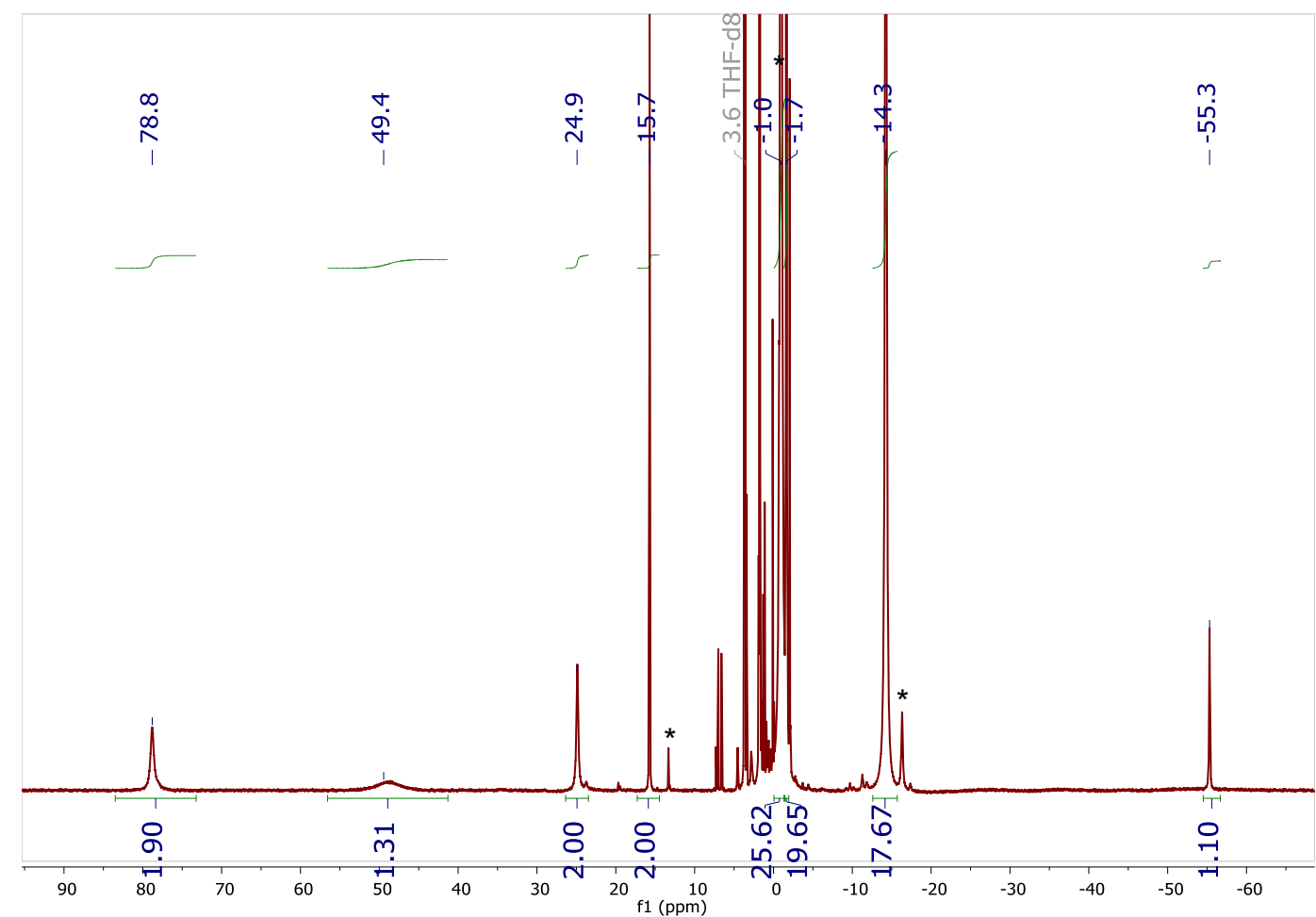

Figure S43. ${ }^{1} \mathrm{H}$ NMR spectrum (THF- $d_{8}, 400 \mathrm{MHz}$ ) of 13. The peaks at 13.3, -2.1 , and $-16.2 \mathrm{ppm}$ marked with an asterisk correspond to hydrolyzed material (see discussion above).

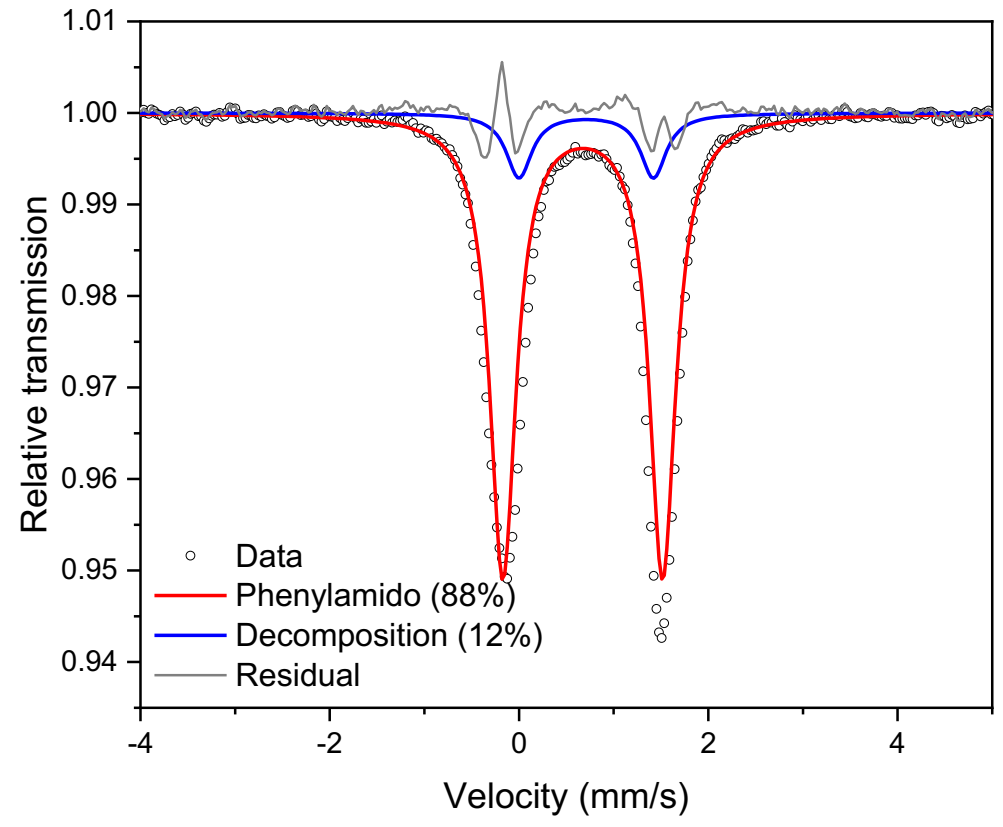

Figure S44. Solid-state Mössbauer spectrum of 13. A $12 \%$ impurity from hydrolyzed material (see discussion above) is included in the fit based on analysis of the ${ }^{1} \mathrm{H}$ NMR spectrum of this material. Fit parameters for 13: $\delta=0.67 \mathrm{~mm} / \mathrm{s},\left|\Delta E_{\mathrm{Q}}\right|=1.69 \mathrm{~mm} / \mathrm{s}, \Gamma_{\mathrm{L}}=\Gamma_{\mathrm{R}}=0.34 \mathrm{~mm} / \mathrm{s}$. 


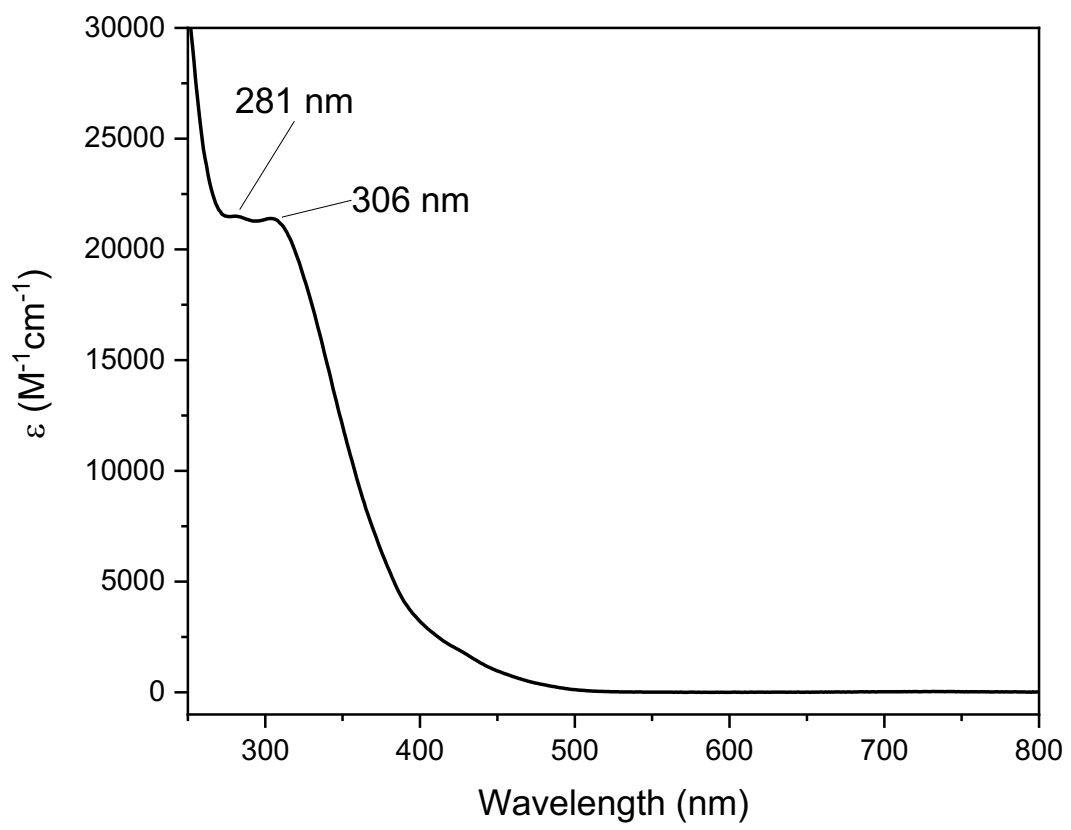

Figure S45. UV-Visible spectrum of 13 in THF.

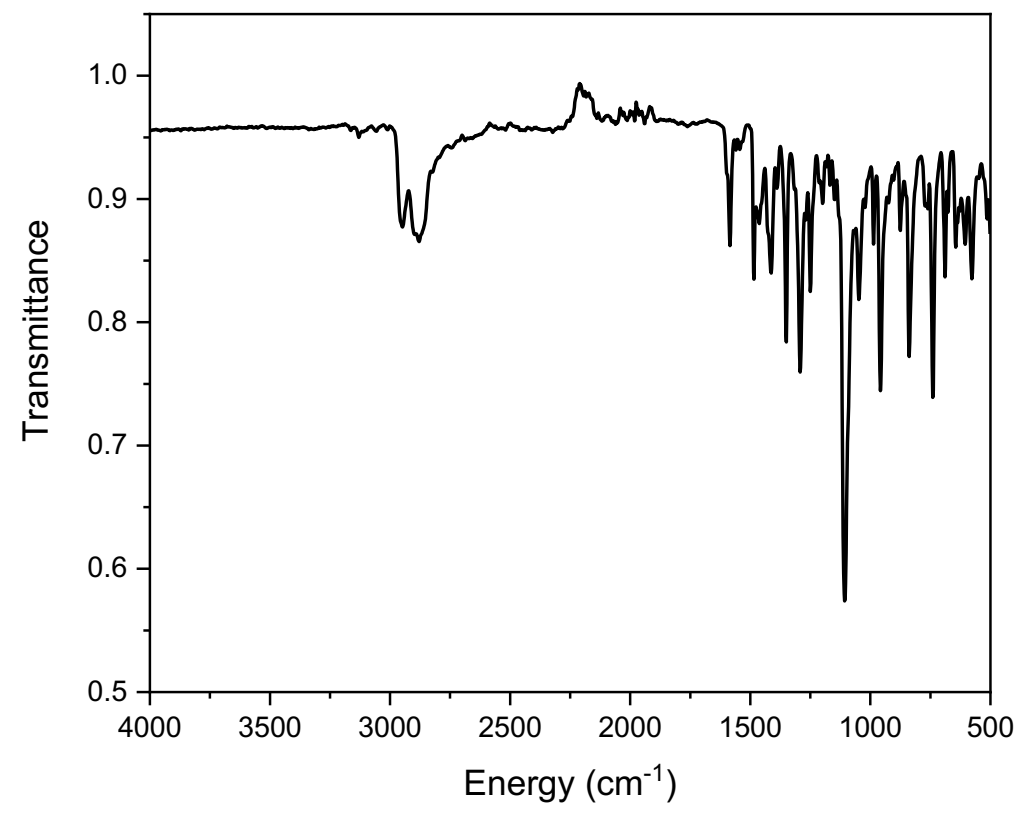

Figure S46. FT-IR spectrum of solid 13. 


\section{Protonation of 10}

Protonation of 10 with stoichiometric acid. In a dry ice / acetone-cooled cold well in an $\mathrm{N}_{2}$-filled glovebox, a solution of $14.1 \mathrm{mg}(13.9 \mu \mathrm{mol})\left[\mathrm{H}\left(\mathrm{OEt}_{2}\right)_{2}\right]\left[\mathrm{BAr}_{4}\right]$ in $1 \mathrm{~mL} \mathrm{THF}$ was added to a solution of $14.3 \mathrm{mg}(13.9$ $\mu \mathrm{mol}) 10 \mathrm{in} 1 \mathrm{~mL}$ THF, resulting in immediate formation of a dark red solution. After $10 \mathrm{~min}$, half of the solution was transferred to a cold Mössbauer cup using a cold pipette. The dry ice / acetone cold well was then quickly replaced with a liquid nitrogen cold well to freeze the sample. The Mössbauer spectrum of this solution (Figure S47, middle panel) reveals complete consumption of the starting material and formation of a complex mixture of species. After stirring overnight at room temperature, the reaction mixture had become a black suspension. The suspension was transferred to a Mössbauer cup and frozen in a liquid nitrogen cold well. Nearly identical spectra were obtained from an analogous experiment performed under argon (Figure S47, blue traces) and an analogous experiment using $\left[\mathrm{HNEt}_{3}\right]\left[\mathrm{BF}_{4}\right]$ as the acid (Figure S48, blue traces).

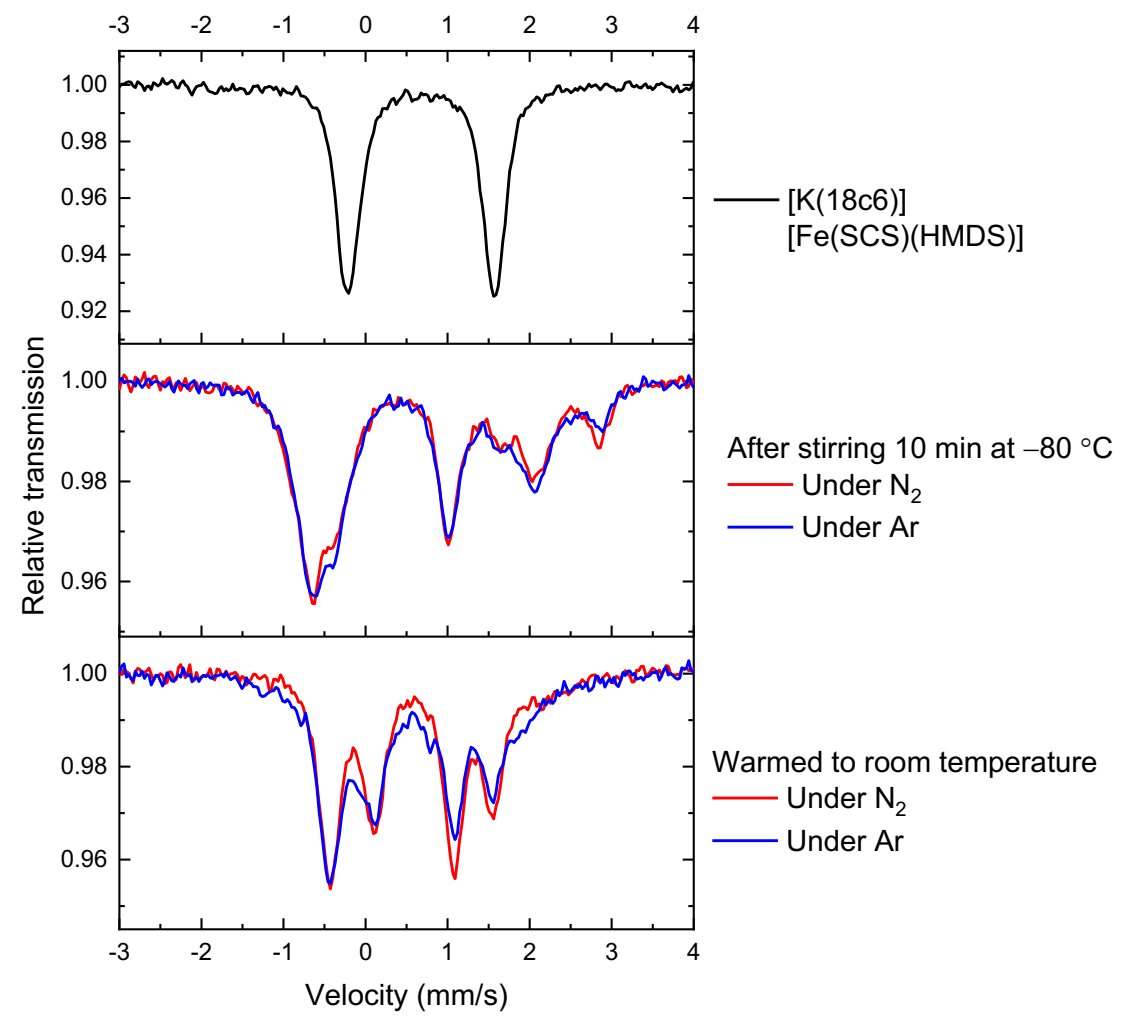

Figure S47. Mössbauer spectra of frozen THF solutions of 10 after treatment with $\left[\mathrm{H}\left(\mathrm{OEt}_{2}\right)_{2}\right]\left[\mathrm{BAr}{ }_{4}\right]$ at -80 ${ }^{\circ} \mathrm{C}$ under $\mathrm{N}_{2}$ (red) and under $\mathrm{Ar}$ (blue). The middle panel shows the initial product of protonation, and the bottom panel shows the final product after warming to room temperature. The spectrum of 10 is shown in the top panel for comparison. 


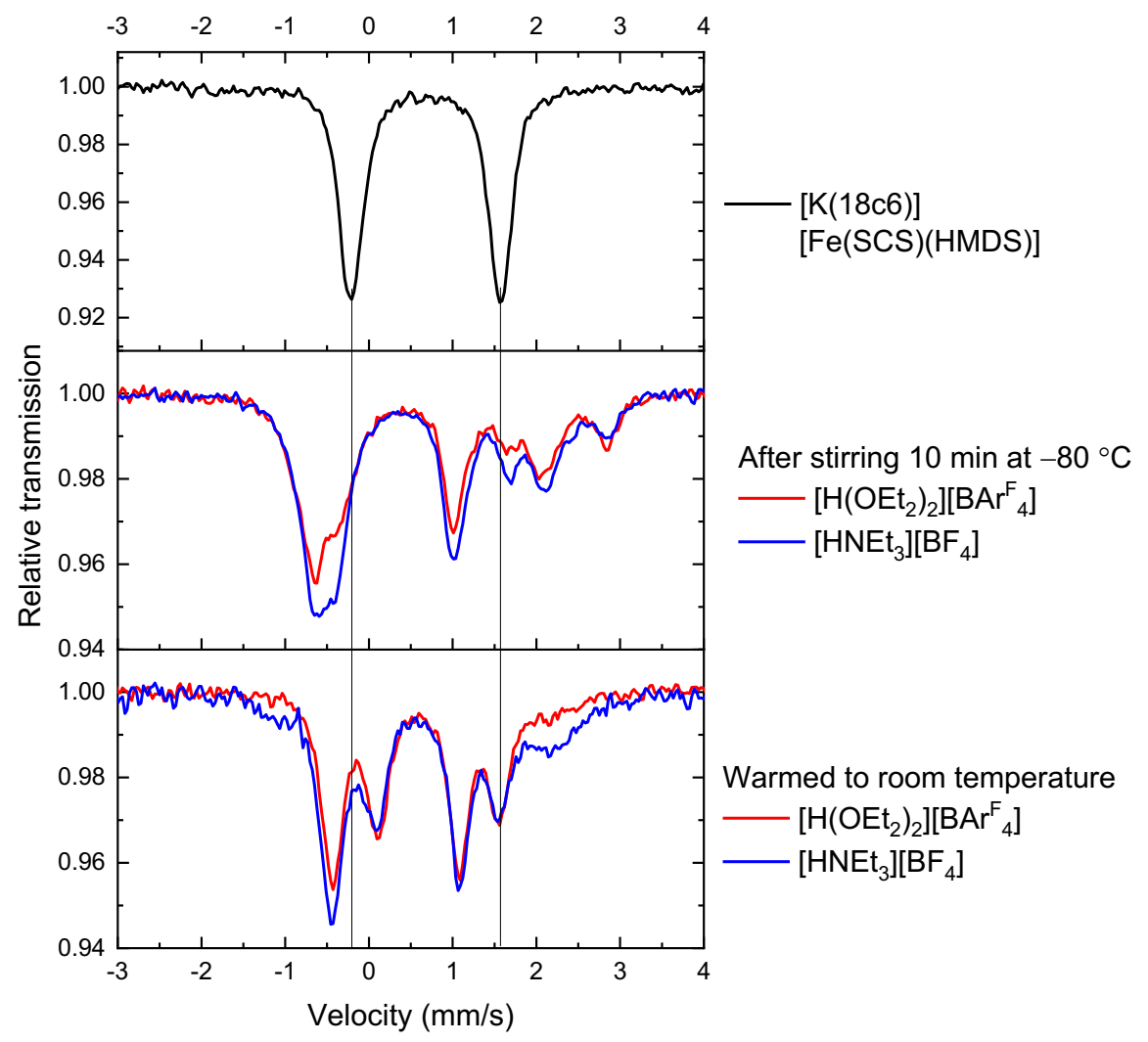

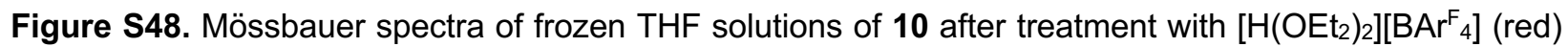
or $\left[\mathrm{HNEt}_{3}\right]\left[\mathrm{BF}_{4}\right]$ (blue) at $-80{ }^{\circ} \mathrm{C}$ under $\mathrm{N}_{2}$. The middle panel shows the initial product of protonation, and the bottom panel shows the final product after warming to room temperature. The spectrum of 10 is shown in the top panel for comparison. 
Protonation of 10 with excess acid. In a dry ice / acetone-cooled cold well in an $\mathrm{N}_{2}$-filled glovebox, a solution of $33.8 \mathrm{mg}\left(33.4 \mu \mathrm{mol}, 5.1\right.$ equiv) $\left[\mathrm{H}\left(\mathrm{OEt}_{2}\right)_{2}\right]\left[\mathrm{BAr}_{4}\right]$ in $0.5 \mathrm{~mL}$ THF was added to a solution of 6.8 $\mathrm{mg}(6.6 \mu \mathrm{mol}) 10 \mathrm{in} 0.5 \mathrm{~mL} \mathrm{THF}$, resulting in an immediate color change from yellow to light red. Over the course of $10 \mathrm{~min}$, the solution became light orange and a colorless precipitate formed. Using a cold pipette, the solution was transferred to a cold Mössbauer cup. The dry ice / acetone cold well was replaced with a liquid nitrogen cold well to freeze the sample. The Mössbauer spectrum of this material indicates different species than those formed upon treatment of $\mathbf{1 0}$ with stoichiometric acid.

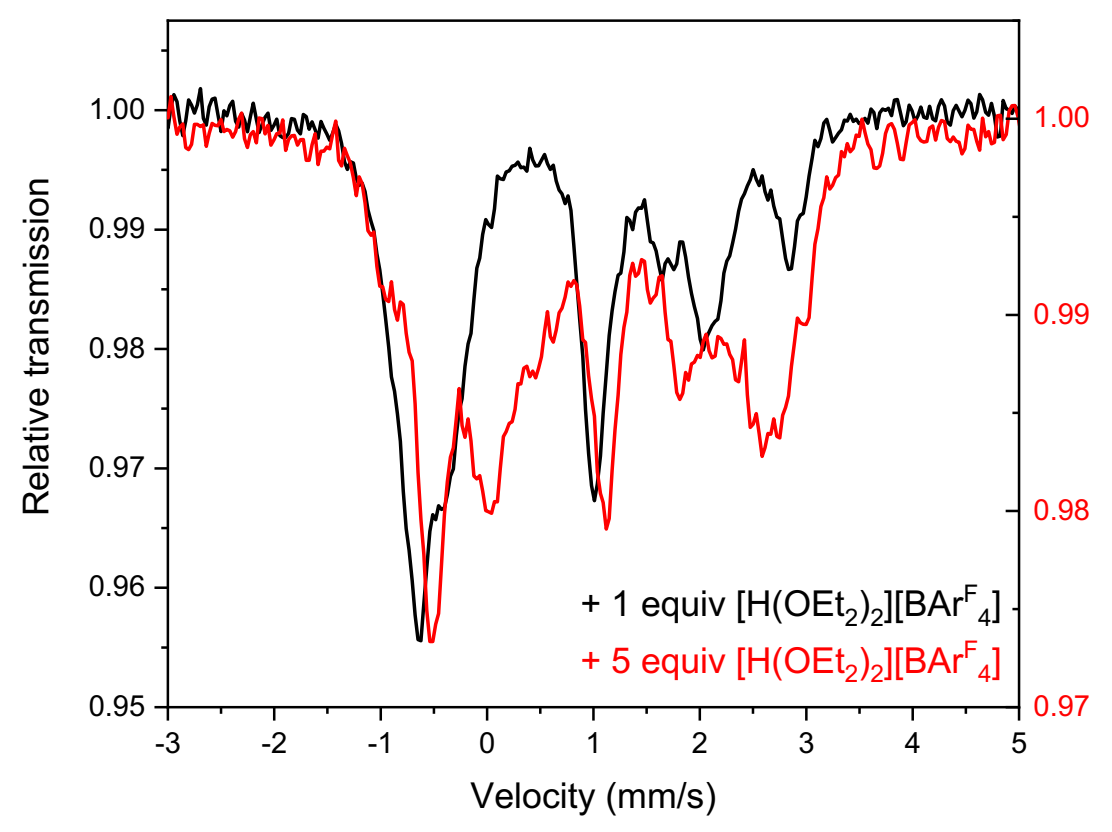

Figure S49. Mössbauer spectra of frozen THF solutions of 10 after treatment with stoichiometric (black) or excess (5 equiv, red) $\left[\mathrm{H}\left(\mathrm{OEt}_{2}\right)_{2}\right]\left[\mathrm{BAr}_{4}\right]$ at $-80^{\circ} \mathrm{C}$. 
Treatment of $\mathbf{1 0}$ with stoichiometric acid and reductant. In a dry ice / acetone-cooled cold well in an $\mathrm{N}_{2}$ filled glovebox, a suspension of $2.2 \mathrm{mg}\left(16.3 \mu \mathrm{mol}, 1.1\right.$ equiv) of $\mathrm{KC}_{8}$ in $0.5 \mathrm{~mL}$ THF was added to a solution of $15.3 \mathrm{mg}(14.9 \mu \mathrm{mol}) 10 \mathrm{in} 0.5 \mathrm{~mL}$ THF. No color change occurred, implying that 10 cannot be reduced by $\mathrm{KC}_{8}$. A solution of $15.7 \mathrm{mg}\left(15.5 \mu \mathrm{mol}, 1.04\right.$ equiv) $\left[\mathrm{H}\left(\mathrm{OEt}_{2}\right)_{2}\right]\left[\mathrm{BAr}_{4}\right]$ in $1.0 \mathrm{~mL} \mathrm{THF}$ was added, causing a color change from light yellow to dark brown. After 10 minutes, an aliquot was transferred to a Mössbauer cup using a cold pipette. The dry ice / acetone cold well was replaced with a liquid nitrogen cold well to freeze the sample. A second aliquot was frozen in the same fashion after stirring at room temperature for 2.5 hours. The Mössbauer spectra of these two samples are similar and contain at least two components different from the products from treatment with $\left[\mathrm{H}\left(\mathrm{OEt}_{2}\right)_{2}\right]\left[\mathrm{BAr}_{4}\right]$ alone.

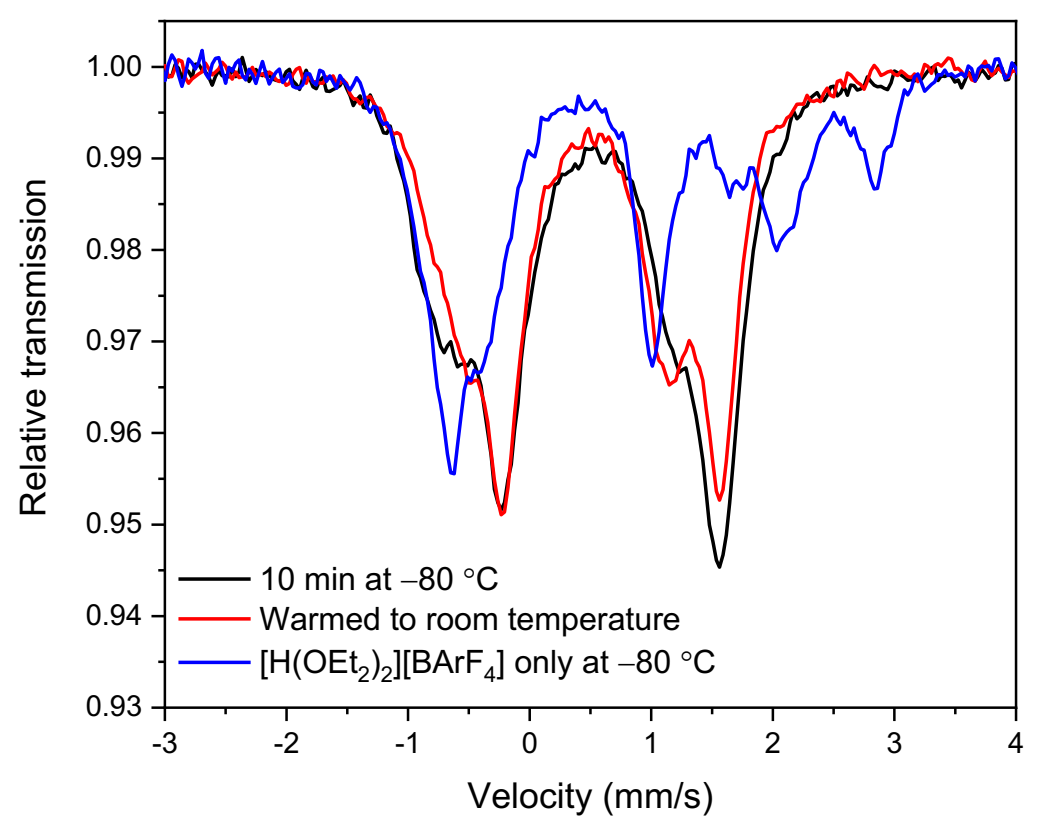

Figure S50. Mössbauer spectra of frozen THF solutions of 10 after treatment with stoichiometric $\mathrm{KC}_{8}$ followed by $\left[\mathrm{H}\left(\mathrm{OEt}_{2}\right)_{2}\right]\left[\mathrm{BAr}_{4}\right]$ at $-80{ }^{\circ} \mathrm{C}$ before (black) and after (red) warming to room temperature. For comparison, a spectrum of 10 after treatment with stoichiometric $\left[\mathrm{H}\left(\mathrm{OEt}_{2}\right)_{2}\right]\left[\mathrm{BAr}_{4}\right]$ in the absence of $\mathrm{KC}_{8}$ is shown in blue. 


\section{$N_{2}$ Reduction Attempts}

Ammonia was quantified using the indophenol method ${ }^{15}$ and hydrazine was quantified using a colorimetric assay. ${ }^{16}$ No hydrazine was detected in any of these reactions. Since only $\sim 1$ equiv of $\mathrm{NH}_{3}$ was formed in these reactions, all of the $\mathrm{NH}_{3}$ is presumably derived from the HMDS ligand in 10. We did not perform follow-up experiments to determine whether any of the positive signal arose from $\mathrm{N}_{2}$-derived $\mathrm{NH}_{3}$.

Representative example for $\mathrm{N}_{2}$ reduction attempts using 10 as a pre-catalyst and $\left[\mathrm{H}\left(\mathrm{OEt}_{2}\right)_{2}\right]\left[\mathrm{BAr}{ }^{\mathrm{F}}\right]$ as an acid. A THF solution containing $2.1 \mathrm{mg}(2.0 \mu \mathrm{mol})$ of 10 was quantitatively transferred to a $100 \mathrm{~mL}$ Schlenk tube and the solvent was removed under vacuum. Solid $\mathrm{KC}_{8}(15 \mathrm{mg}, 111 \mu \mathrm{mol}, 55$ equiv) and [H(OEt $\left.)_{2}\right)_{[}\left[\mathrm{BAr}^{\mathrm{F}}\right]$ (93 mg, $92 \mu \mathrm{mol}, 46$ equiv) were added and the flask was sealed with a rubber septum. The flask was placed in a liquid nitrogen-cooled glovebox cold well for $10 \mathrm{~min}$. Using a syringe, $3 \mathrm{~mL}$ of diethyl ether was slowly added through the septum. The flask was transferred out of the glovebox to a dry ice/acetone cold bath. After 1.5 hours at $-80^{\circ} \mathrm{C}$, the reaction mixture was warmed to room temperature. The resulting suspension was frozen in liquid nitrogen and $2.5 \mathrm{~mL}$ of $175 \mathrm{mM}$ sodium tert-butoxide in methanol was slowly added via syringe. After the solution had frozen, the septum was replaced with a $180^{\circ}$ adapter equipped with a Teflon valve and the flask was evacuated. The reaction mixture was thawed and stirred at room temperature for one hour. The contents of the flask were then vacuum transferred to a flask containing $3 \mathrm{~mL}$ of $2 \mathrm{M} \mathrm{HCl}$ in diethyl ether. The volatile materials were removed from the receiving flask, and the residue in the flask was dissolved in phosphate-buffered water $(\mathrm{pH}=7.2)$ and analyzed for ammonia and hydrazine.

Scheme S2. Yields of $\mathrm{NH}_{3}$ (per iron) from treatment of 10 with excess acid and reductant.

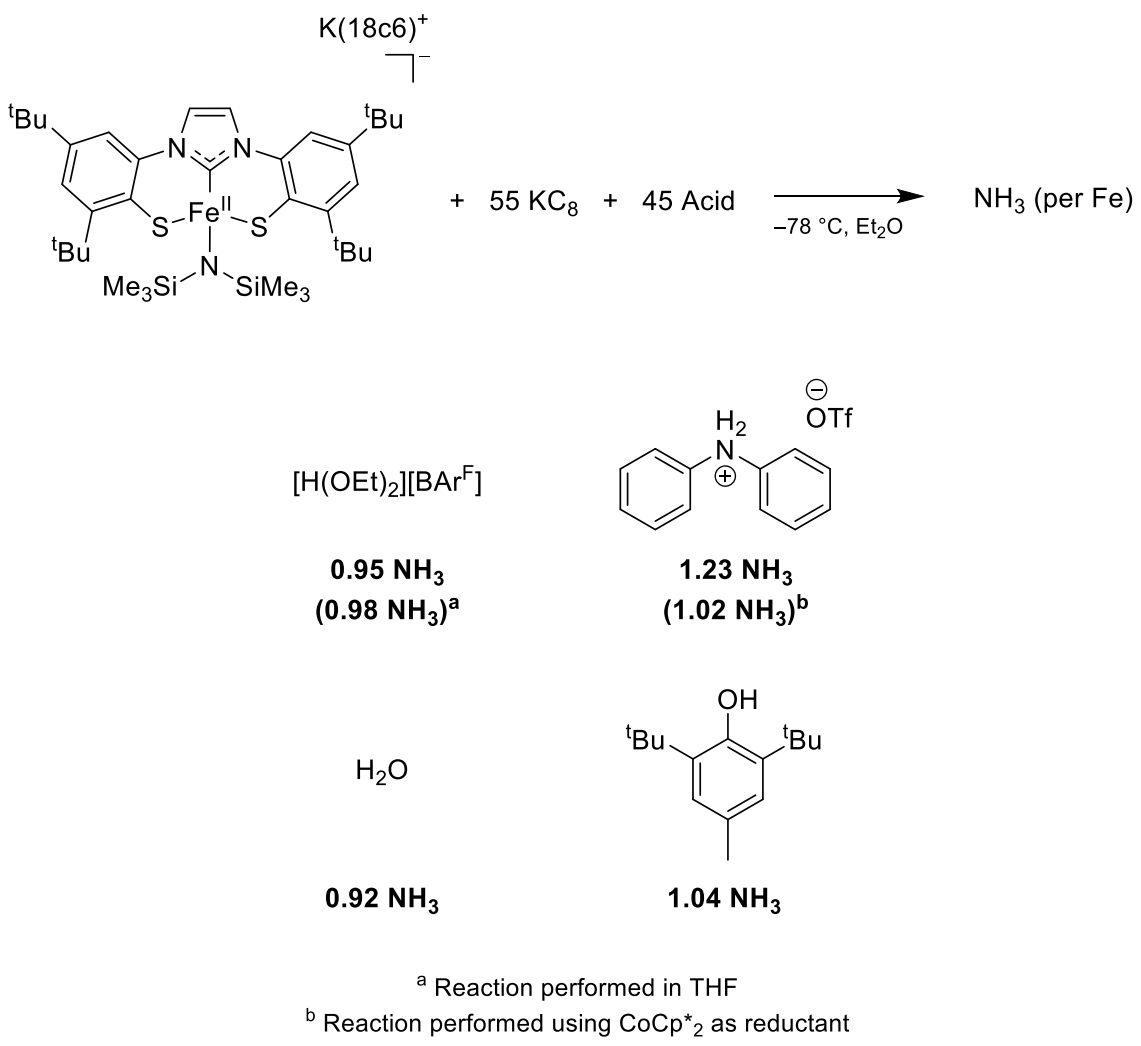




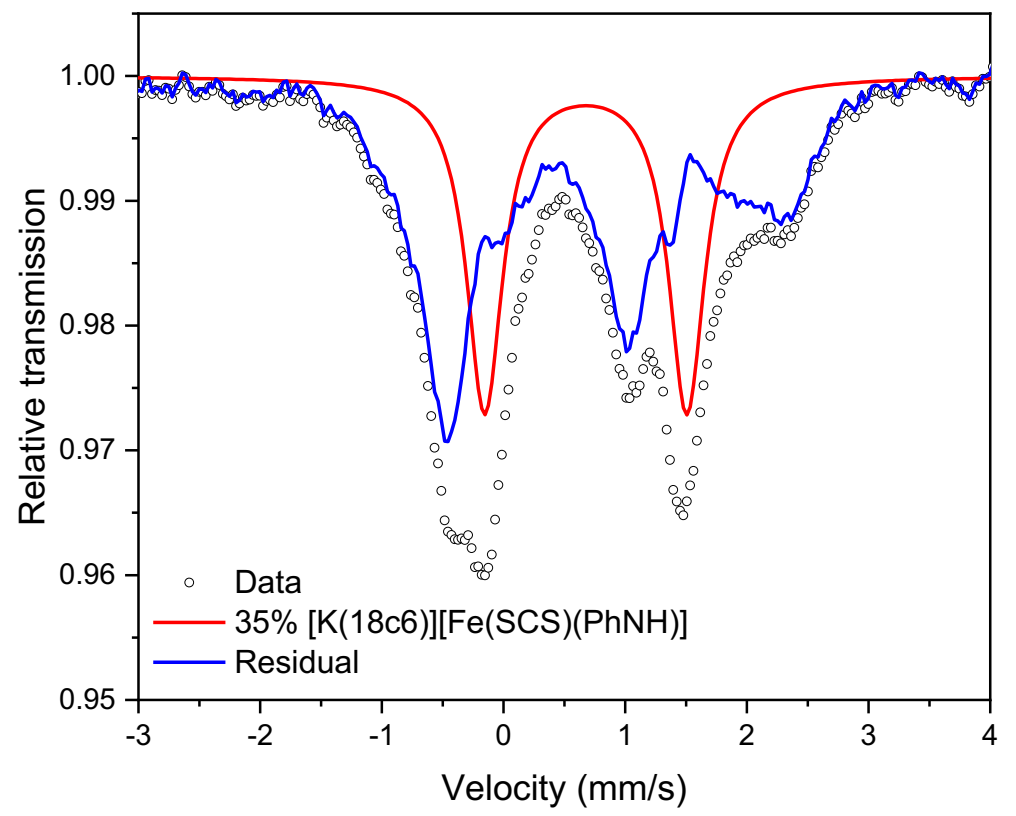

Figure S51. Mössbauer spectrum of a frozen THF solution of 12 after heating at $70{ }^{\circ} \mathrm{C}$ for $2.5 \mathrm{hr}$. The data are shown as circles, and the red line is a fit for a $35 \%$ contribution from 13 which was determined by ${ }^{1} \mathrm{H}$ NMR spectroscopy. The remaining signal is shown as a blue line. 


\section{Crystallographic Data}

Crystallographic details for 8. Crystals suitable for XRD were grown by layering a concentrated THF solution of 8 with pentane and storing overnight in a freezer at $-40^{\circ} \mathrm{C}$. Low-temperature diffraction data $(\omega$ scans) were collected on a Rigaku MicroMax-007HF diffractometer coupled to a Saturn994+ CCD detector with $\mathrm{Cu} \mathrm{Ka}(\lambda=1.54178 \AA)$. The diffraction images were processed and scaled using Rigaku Oxford Diffraction software. ${ }^{17}$ The structure was solved with SHELXT and was refined against $F^{2}$ on all data by fullmatrix least squares with SHELXL. ${ }^{18}$

Several attempts were made to recollect this data, and the model reported here was found to have the best metrics. The solution here is sufficient only to establish the connectivity of the iron complex. All nonhydrogen atoms were refined anisotropically. Hydrogen atoms were included in the model at geometrically calculated positions and refined using a riding model. The isotropic displacement parameters of all hydrogen atoms were fixed to 1.2 times the $U$ value of the atoms to which they are linked (1.5 times for methyl groups). The model was found to have whole molecule disorder. The thermal parameters of each component of the disorder model were restrained to globally behave as a rigid bodies. In addition, the anisotropic thermal parameters were restrained so that their Uij components approximate to isotropic behavior.

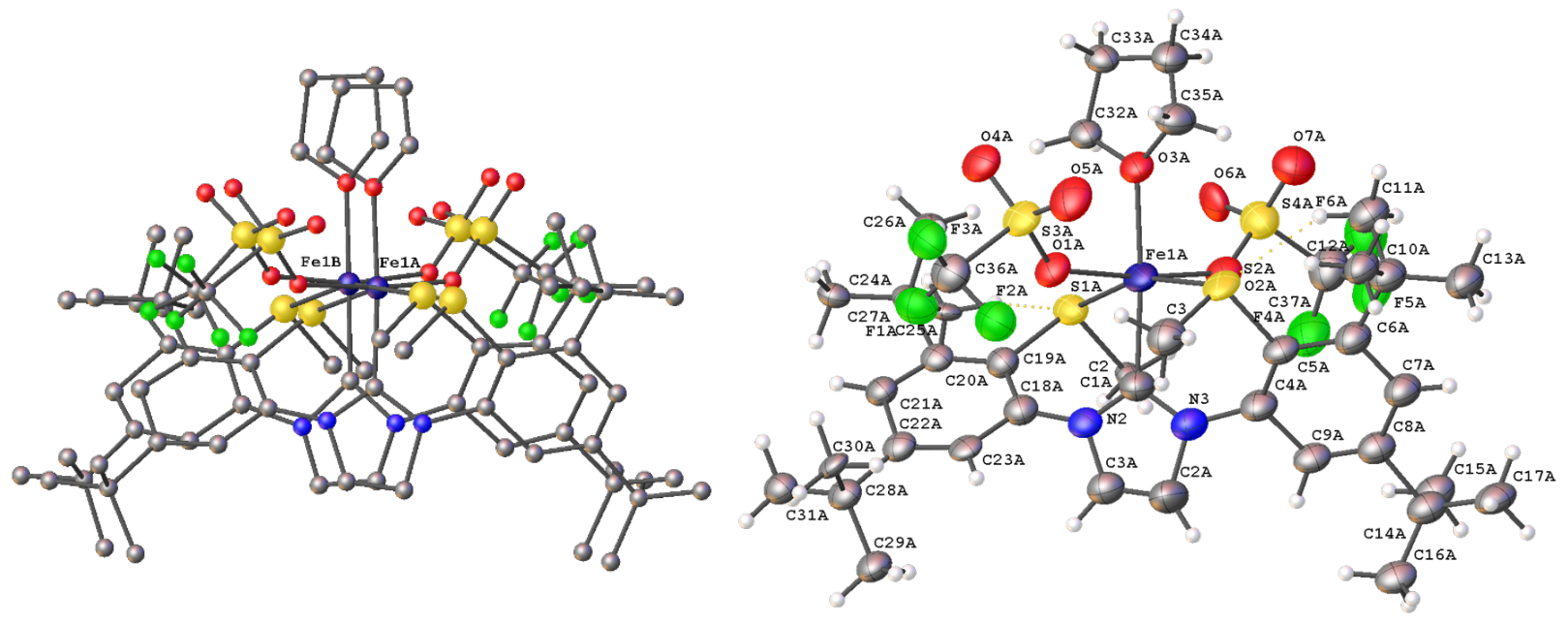

Figure S52. (Left) The complete model of 8 with 50\% thermal ellipsoids. The hydrogen atoms are omitted for clarity. (Right) The complete numbering of 8 (part 1) with $50 \%$ thermal ellipsoids. 
Table S3. Crystal data and structure refinement for $\mathbf{8}$.

\begin{tabular}{|c|c|c|}
\hline Identification code & \multicolumn{2}{|l|}{$007 b-17103$} \\
\hline Empirical formula & \multicolumn{2}{|c|}{ C39 H56 F6 Fe N2 O7 S4 } \\
\hline Formula weight & \multicolumn{2}{|l|}{962.94} \\
\hline Temperature & \multicolumn{2}{|l|}{$93(2) \mathrm{K}$} \\
\hline Wavelength & \multicolumn{2}{|l|}{$1.54184 \AA$} \\
\hline Crystal system & \multicolumn{2}{|l|}{ Monoclinic } \\
\hline Space group & \multicolumn{2}{|l|}{$\mathrm{P} 21 / \mathrm{c}$} \\
\hline \multirow[t]{3}{*}{ Unit cell dimensions } & $a=23.674(5) \AA$ & $\alpha=90^{\circ}$ \\
\hline & $b=10.1166(5) \AA$ & $\beta=112.41(2)^{\circ}$. \\
\hline & $c=20.895(3) \AA$ & $\gamma=90^{\circ}$ \\
\hline Volume & \multicolumn{2}{|l|}{$4626.3(13) \AA^{3}$} \\
\hline Z & \multicolumn{2}{|l|}{4} \\
\hline Density (calculated) & \multicolumn{2}{|l|}{$1.383 \mathrm{~g} / \mathrm{cm}^{3}$} \\
\hline Absorption coefficient & \multicolumn{2}{|l|}{$4.918 \mathrm{~mm}^{-1}$} \\
\hline$F(000)$ & \multicolumn{2}{|l|}{2016} \\
\hline Crystal size & \multicolumn{2}{|c|}{$0.050 \times 0.040 \times 0.020 \mathrm{~mm}^{3}$} \\
\hline Crystal color and habit & \multicolumn{2}{|l|}{ Colorless Block } \\
\hline Diffractometer & \multicolumn{2}{|c|}{ Rigaku Saturn 944+ CCD } \\
\hline Theta range for data collection & \multicolumn{2}{|l|}{2.019 to $42.102^{\circ}$} \\
\hline Index ranges & \multicolumn{2}{|c|}{$-20<=\mathrm{h}<=20,-8<=\mathrm{k}<=8,-18<=\mid<=18$} \\
\hline Reflections collected & \multicolumn{2}{|l|}{86374} \\
\hline Independent reflections & \multicolumn{2}{|c|}{$3185[R($ int $)=0.2043]$} \\
\hline Observed reflections $(\mathrm{I}>2$ sigma $(\mathrm{I}))$ & \multicolumn{2}{|l|}{2398} \\
\hline Completeness to theta $=42.102^{\circ}$ & \multicolumn{2}{|l|}{$99.9 \%$} \\
\hline Absorption correction & \multicolumn{2}{|c|}{ Semi-empirical from equivalents } \\
\hline Max. and min. transmission & \multicolumn{2}{|c|}{1.00000 and 0.56244} \\
\hline Solution method & \multicolumn{2}{|c|}{ SHELXT-2014/5 (Sheldrick, 2014) } \\
\hline Refinement method & \multicolumn{2}{|c|}{ SHELXL-2014/7 (Sheldrick, 2014) } \\
\hline Data / restraints / parameters & \multicolumn{2}{|l|}{3185 / 1794 / 1090} \\
\hline Goodness-of-fit on $\mathrm{F}^{2}$ & \multicolumn{2}{|l|}{1.063} \\
\hline Final $R$ indices [l>2sigma(I)] & \multicolumn{2}{|c|}{$\mathrm{R} 1=0.1250, w R 2=0.2956$} \\
\hline $\mathrm{R}$ indices (all data) & \multicolumn{2}{|c|}{$\mathrm{R} 1=0.1480, w R 2=0.3159$} \\
\hline Largest diff. peak and hole & \multicolumn{2}{|c|}{0.574 and -0.803 e. $\AA^{-3}$} \\
\hline
\end{tabular}


Crystallographic details for 9 . Single crystals suitable for XRD were grown by layering a concentrated $\mathrm{CH}_{3} \mathrm{CN}$ solution of 9 with diethyl ether and storing in a freezer at $-40{ }^{\circ} \mathrm{C}$ overnight. Low-temperature diffraction data ( $\omega$-scans) were collected on a Rigaku MicroMax-007HF diffractometer coupled to a Dectris Pilatus3R detector with Mo Ka $(\lambda=0.71073 \AA)$. The diffraction images were processed and scaled using Rigaku Oxford Diffraction software. ${ }^{17}$ The structure was solved with SHELXT and was refined against $\mathrm{F}^{2}$ on all data by full-matrix least squares with SHELXL. ${ }^{18}$ All non-hydrogen atoms were refined anisotropically. Hydrogen atoms were included in the model at geometrically calculated positions and refined using a riding model. The isotropic displacement parameters of all hydrogen atoms were fixed to 1.2 times the $U$ value of the atoms to which they are linked (1.5 times for methyl groups).

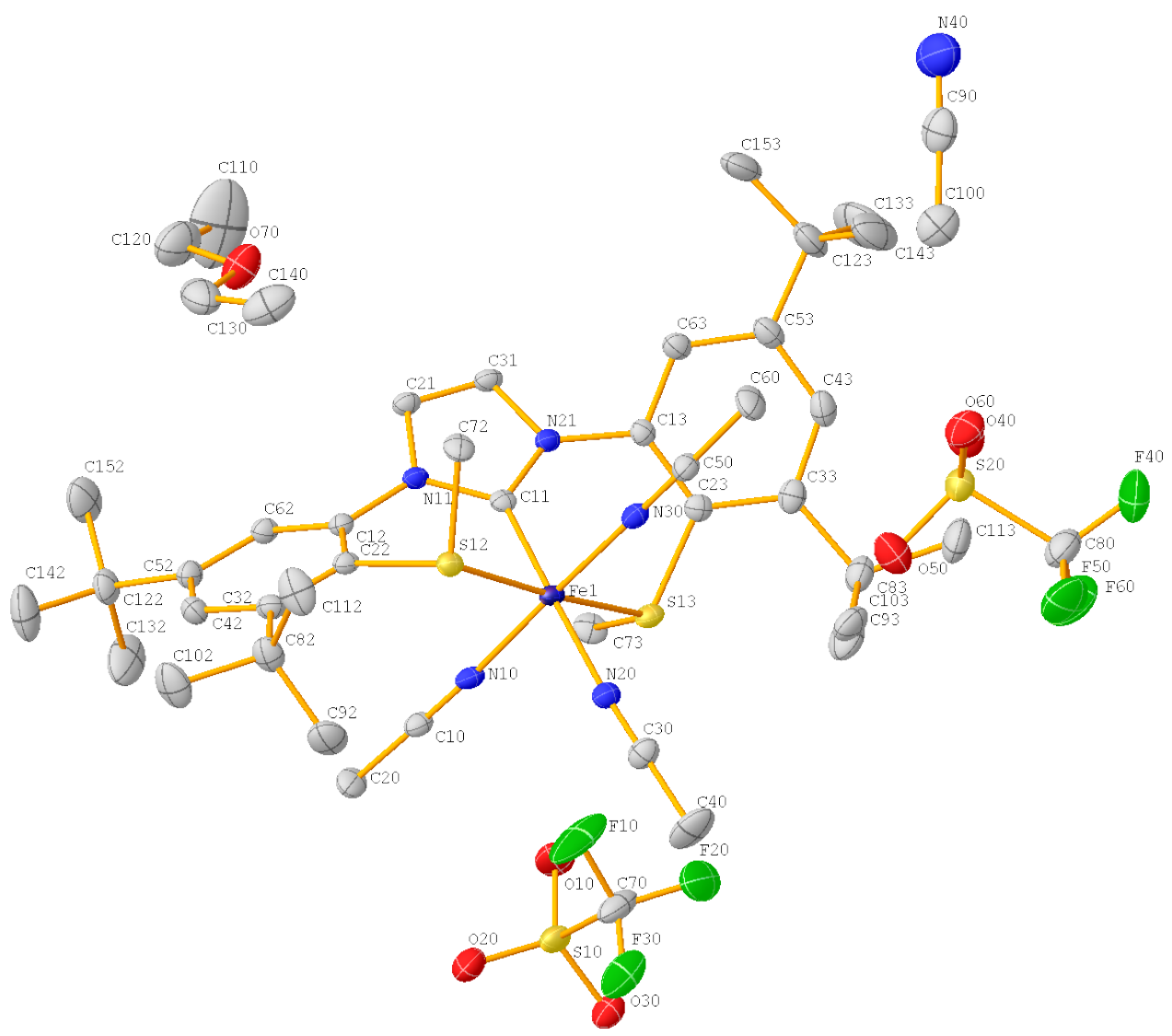

Figure S53. The complete numbering scheme of 9 with $50 \%$ thermal ellipsoids. The hydrogen atoms are omitted for clarity. 
Table S4. Crystal data and structure refinement for $\mathbf{9}$.

\begin{tabular}{|c|c|c|}
\hline Identification code & \multicolumn{2}{|l|}{$007 c-17045$} \\
\hline Empirical formula & \multicolumn{2}{|c|}{ C47 H70 F6 Fe N6 O7 S4 } \\
\hline Formula weight & \multicolumn{2}{|l|}{1129.18} \\
\hline Temperature & \multicolumn{2}{|l|}{$93(2) \mathrm{K}$} \\
\hline Wavelength & \multicolumn{2}{|l|}{$0.71073 \AA$} \\
\hline Crystal system & \multicolumn{2}{|l|}{ Monoclinic } \\
\hline Space group & \multicolumn{2}{|l|}{$\mathrm{C} 2 / \mathrm{c}$} \\
\hline \multirow[t]{3}{*}{ Unit cell dimensions } & $a=29.4822(8) \AA$ & $\alpha=90^{\circ}$. \\
\hline & $b=21.1784(4) \AA$ & $\beta=109.122(3)^{\circ}$. \\
\hline & $c=19.4175(5) \AA$ & $\gamma=90^{\circ}$ \\
\hline Volume & \multicolumn{2}{|l|}{$11455.0(5) \AA^{3}$} \\
\hline Z & \multicolumn{2}{|l|}{8} \\
\hline Density (calculated) & \multicolumn{2}{|l|}{$1.309 \mathrm{~g} / \mathrm{cm}^{-1}$} \\
\hline$F(000)$ & \multicolumn{2}{|l|}{4752} \\
\hline Crystal size & \multicolumn{2}{|c|}{$0.200 \times 0.200 \times 0.050 \mathrm{~mm}^{3}$} \\
\hline Crystal color and habit & \multicolumn{2}{|l|}{ Red Block } \\
\hline Diffractometer & \multicolumn{2}{|l|}{ Dectris Pilatus 3R } \\
\hline Theta range for data collection & \multicolumn{2}{|l|}{2.925 to $27.485^{\circ}$. } \\
\hline Index ranges & \multicolumn{2}{|c|}{$-38<=\mathrm{h}<=38,-27<=\mathrm{k}<=27,-20<=\mathrm{l}<=25$} \\
\hline Reflections collected & \multicolumn{2}{|l|}{69150} \\
\hline Independent reflections & \multicolumn{2}{|c|}{$13128[R($ int $)=0.0245]$} \\
\hline Observed reflections $(\mathrm{I}>2$ sigma $(\mathrm{I}))$ & \multicolumn{2}{|l|}{11558} \\
\hline Completeness to theta $=25.242^{\circ}$ & \multicolumn{2}{|l|}{$99.8 \%$} \\
\hline Absorption correction & \multicolumn{2}{|c|}{ Semi-empirical from equivalents } \\
\hline Max. and min. transmission & \multicolumn{2}{|c|}{1.00000 and 0.83140} \\
\hline Solution method & \multicolumn{2}{|c|}{ SHELXT-2014/5 (Sheldrick, 2014) } \\
\hline Refinement method & \multicolumn{2}{|c|}{ SHELXL-2014/7 (Sheldrick, 2014) } \\
\hline Data / restraints / parameters & \multicolumn{2}{|l|}{$13128 / 0 / 660$} \\
\hline Goodness-of-fit on $F^{2}$ & \multicolumn{2}{|l|}{1.120} \\
\hline Final R indices [l>2sigma(l)] & \multicolumn{2}{|c|}{$\mathrm{R} 1=0.0474, \mathrm{wR} 2=0.1213$} \\
\hline $\mathrm{R}$ indices (all data) & \multicolumn{2}{|c|}{$\mathrm{R} 1=0.0546, \mathrm{wR} 2=0.1251$} \\
\hline Largest diff. peak and hole & \multicolumn{2}{|c|}{1.086 and -0.675 e. $\AA^{-3}$} \\
\hline
\end{tabular}


Crystallographic details for 10 . Single crystals suitable for XRD were grown by storing a concentrated diethyl ether solution of 10 at $-40^{\circ} \mathrm{C}$ overnight. Low-temperature diffraction data ( $\omega$-scans) were collected on a Rigaku MicroMax-007HF diffractometer coupled to a Saturn994+ CCD detector with $\mathrm{Cu} \mathrm{Ka}(\lambda=$ $1.54178 \AA$ ) for the structure of $007 \mathrm{~b}-18116$. The diffraction images were processed and scaled using Rigaku Oxford Diffraction software. ${ }^{17}$ The structure was solved with SHELXT and was refined against $\mathrm{F}^{2}$ on all data by full-matrix least squares with SHELXL. ${ }^{18}$ All non-hydrogen atoms were refined anisotropically. Hydrogen atoms were included in the model at geometrically calculated positions and refined using a riding model. The isotropic displacement parameters of all hydrogen atoms were fixed to 1.2 times the $U$ value of the atoms to which they are linked (1.5 times for methyl groups). Many reflections were improperly recorded due to instrument artifacts (icing), and they were omitted from the least squares refinement.

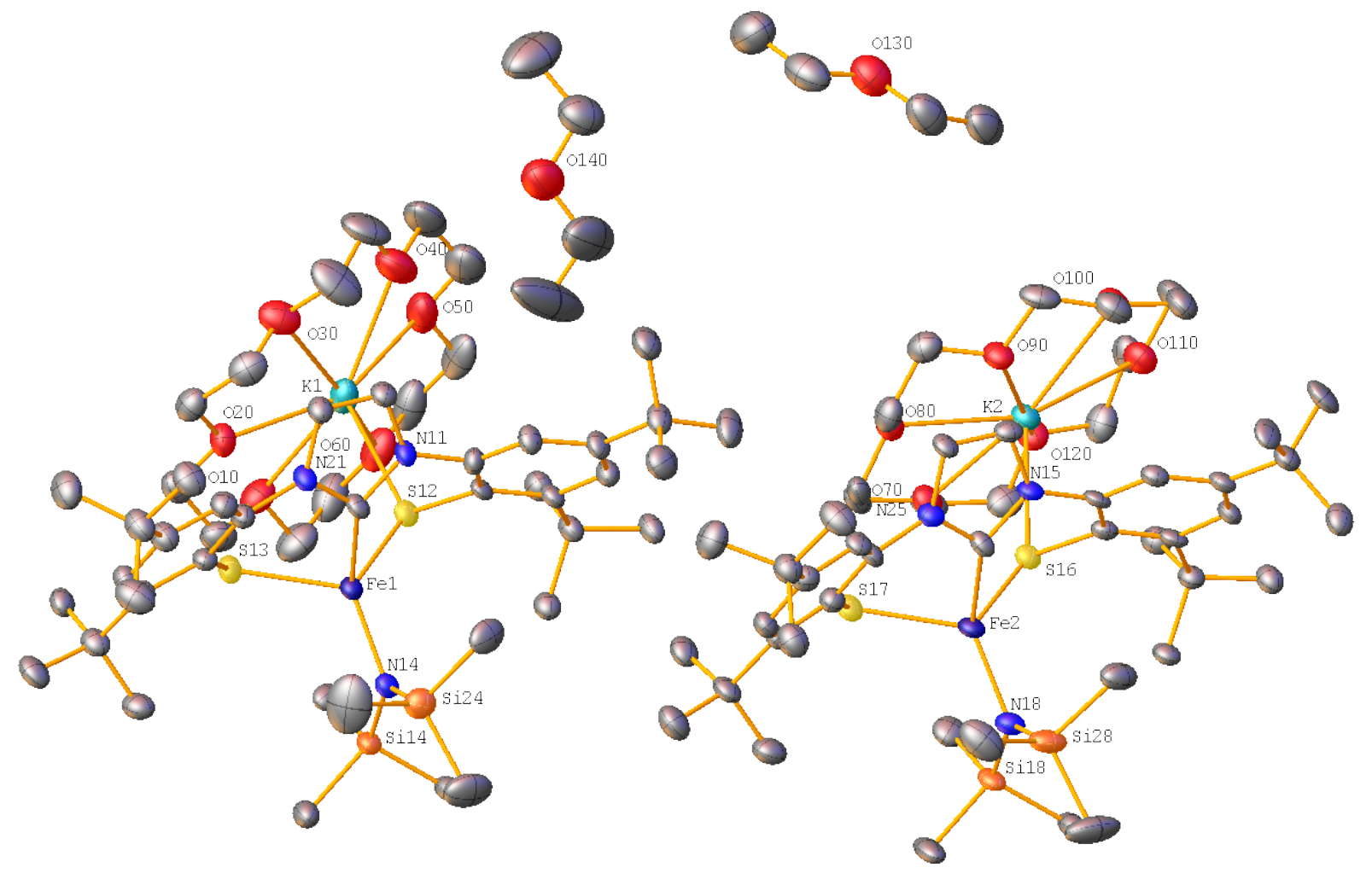

Figure S54. A partial numbering scheme for 10 with 50\% thermal ellipsoids. The hydrogen atoms are omitted for clarity. 
Table S5. Crystal data and structure refinement for 10.

\begin{tabular}{|c|c|c|}
\hline Identification code & \multicolumn{2}{|l|}{ 007b-18116 } \\
\hline Empirical formula & \multicolumn{2}{|c|}{ C53 H94 Fe K N3 O7 S2 Si2 } \\
\hline Formula weight & \multicolumn{2}{|l|}{1100.56} \\
\hline Temperature & \multicolumn{2}{|l|}{$93(2) \mathrm{K}$} \\
\hline Wavelength & \multicolumn{2}{|l|}{$1.54184 \AA$} \\
\hline Crystal system & \multicolumn{2}{|l|}{ Monoclinic } \\
\hline Space group & \multicolumn{2}{|l|}{$\mathrm{P} 2{ }_{1} / \mathrm{c}$} \\
\hline \multirow[t]{3}{*}{ Unit cell dimensions } & $a=24.3845(4) \AA$ & $\alpha=90^{\circ}$. \\
\hline & $b=23.5048(3) \AA$ & $\beta=105.448(2)^{\circ}$. \\
\hline & $c=22.9343(3) \AA$ & $\gamma=90^{\circ}$ \\
\hline Volume & \multicolumn{2}{|l|}{$12670.0(3) \AA^{3}$} \\
\hline Z & \multicolumn{2}{|l|}{8} \\
\hline Density (calculated) & \multicolumn{2}{|l|}{$1.154 \mathrm{~g} / \mathrm{cm}^{3}$} \\
\hline Absorption coefficient & \multicolumn{2}{|l|}{$3.836 \mathrm{~mm}^{-1}$} \\
\hline$F(000)$ & \multicolumn{2}{|l|}{4752} \\
\hline Crystal size & \multicolumn{2}{|c|}{$0.200 \times 0.200 \times 0.090 \mathrm{~mm}^{3}$} \\
\hline Crystal color and habit & \multicolumn{2}{|l|}{ Yellow Block } \\
\hline Diffractometer & \multicolumn{2}{|c|}{ Rigaku Saturn 944+ CCD } \\
\hline Theta range for data collection & \multicolumn{2}{|l|}{1.880 to $66.570^{\circ}$. } \\
\hline Index ranges & \multicolumn{2}{|c|}{$-27<=\mathrm{h}<=28,-27<=\mathrm{k}<=27,-27<=\mid<=27$} \\
\hline Reflections collected & \multicolumn{2}{|l|}{441441} \\
\hline Independent reflections & \multicolumn{2}{|c|}{$22271[\mathrm{R}(\mathrm{int})=0.0906]$} \\
\hline Observed reflections $(\mathrm{I}>2$ sigma $(\mathrm{I}))$ & \multicolumn{2}{|l|}{19179} \\
\hline Completeness to theta $=66.570^{\circ}$ & \multicolumn{2}{|l|}{$99.6 \%$} \\
\hline Absorption correction & \multicolumn{2}{|c|}{ Semi-empirical from equivalents } \\
\hline Max. and min. transmission & \multicolumn{2}{|c|}{1.00000 and 0.52823} \\
\hline Solution method & \multicolumn{2}{|c|}{ SHELXT-2014/5 (Sheldrick, 2014) } \\
\hline Refinement method & \multicolumn{2}{|c|}{ SHELXL-2014/7 (Sheldrick, 2014) } \\
\hline Data / restraints / parameters & \multicolumn{2}{|l|}{$22271 / 0 / 1283$} \\
\hline Goodness-of-fit on $\mathrm{F}^{2}$ & \multicolumn{2}{|l|}{1.154} \\
\hline Final R indices [l>2sigma(I)] & \multicolumn{2}{|c|}{$\mathrm{R} 1=0.0926, \mathrm{wR} 2=0.2381$} \\
\hline $\mathrm{R}$ indices (all data) & \multicolumn{2}{|c|}{$\mathrm{R} 1=0.1030, \mathrm{wR} 2=0.2442$} \\
\hline Largest diff. peak and hole & \multicolumn{2}{|c|}{1.457 and -0.999 e. $\AA^{-3}$} \\
\hline
\end{tabular}


Crystallographic details for 11. Crystals suitable for XRD were grown by layering a concentrated THF solution of 11 with hexanes and storing overnight in a $-40^{\circ} \mathrm{C}$ freezer. Low-temperature diffraction data $(\omega$ scans) were collected on a Rigaku MicroMax-007HF diffractometer coupled to a Dectris Pilatus3R detector with Mo Ka $(\lambda=0.71073 \AA)$. The diffraction images were processed and scaled using Rigaku Oxford Diffraction software. ${ }^{17}$ The structure was solved with SHELXT and was refined against $F^{2}$ on all data by fullmatrix least squares with SHELXL. ${ }^{18}$ All non-hydrogen atoms were refined anisotropically. Hydrogen atoms were included in the model at geometrically calculated positions and refined using a riding model. The isotropic displacement parameters of all hydrogen atoms were fixed to 1.2 times the $U$ value of the atoms to which they are linked (1.5 times for methyl groups). The program SQUEEZE was used to compensate for the contribution of disordered solvent contained in voids within the crystal lattice from the diffraction intensities. This procedure was applied to the data file and the submitted model is based on the solvent removed data. Based on the total electron density found in the voids $\left(259 \mathrm{e} / \AA^{3}\right)$, it is likely that $\sim 7 \mathrm{THF}$ molecules are present in the unit cell. See "_platon_squeeze_details" in the .cif for more information.

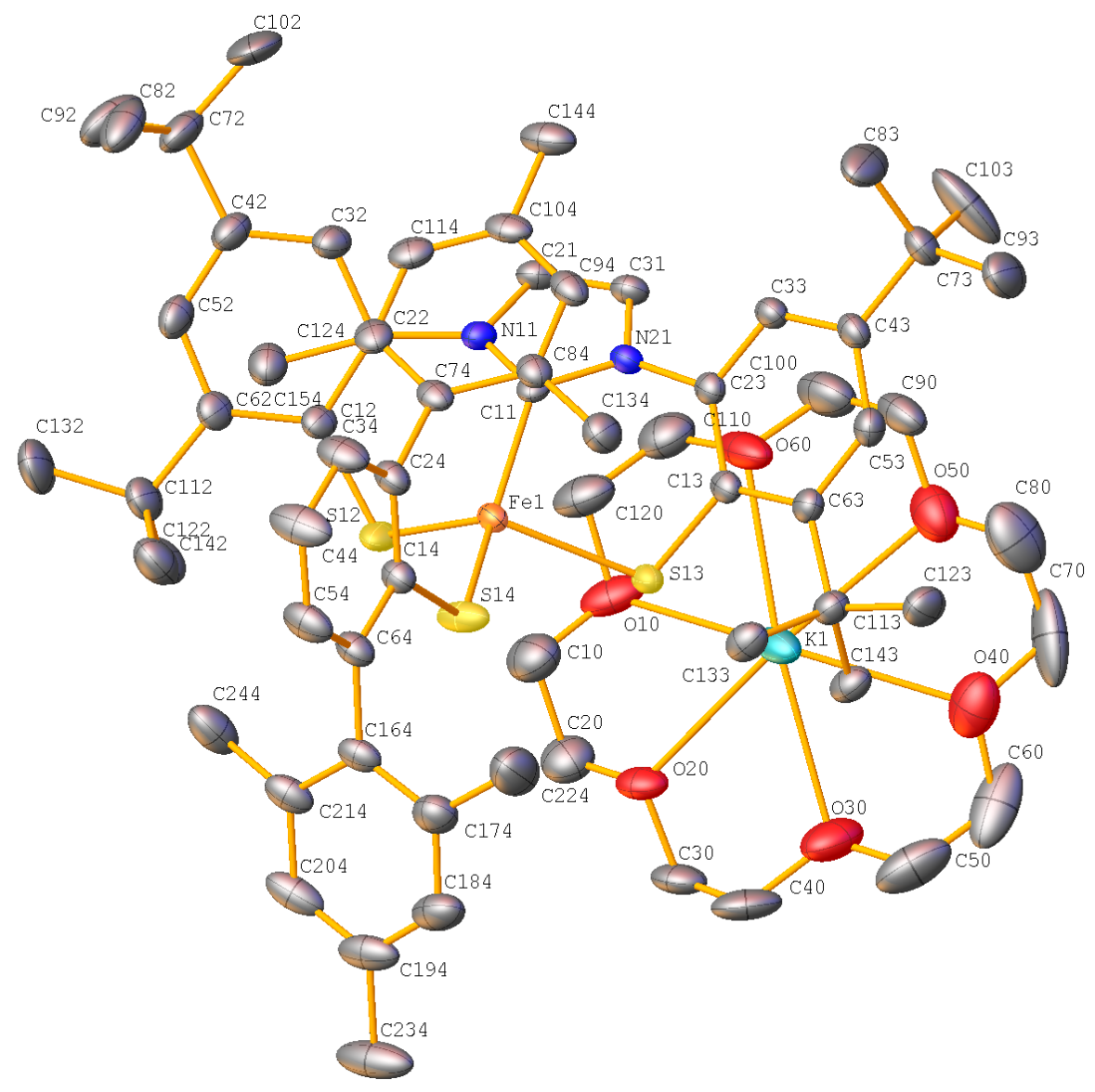

Figure S55. The complete numbering scheme of 11 with 50\% thermal ellipsoids. The hydrogen atoms are omitted for clarity. 
Table S6. Crystal data and structure refinement for 11.

\begin{tabular}{|c|c|c|}
\hline Identification code & \multicolumn{2}{|l|}{ 007c-18078 } \\
\hline Empirical formula & \multicolumn{2}{|c|}{ C67 H91 Fe K N2 O6 S3 } \\
\hline Formula weight & \multicolumn{2}{|l|}{1211.54} \\
\hline Temperature & \multicolumn{2}{|l|}{$93(2) \mathrm{K}$} \\
\hline Wavelength & \multicolumn{2}{|l|}{$0.71073 \AA$} \\
\hline Crystal system & \multicolumn{2}{|l|}{ Triclinic } \\
\hline Space group & \multicolumn{2}{|l|}{$P-1$} \\
\hline \multirow[t]{3}{*}{ Unit cell dimensions } & $a=15.1018(10) \AA$ & $\alpha=73.252(5)^{\circ}$. \\
\hline & $b=15.7094(10) \AA$ & $\beta=74.974(4)^{\circ}$. \\
\hline & $c=20.3943(9) \AA$ & $\gamma=61.355(7)^{\circ}$ \\
\hline Volume & \multicolumn{2}{|l|}{$4023.6(5) \AA^{3}$} \\
\hline Z & \multicolumn{2}{|l|}{2} \\
\hline Density (calculated) & \multicolumn{2}{|l|}{$1.000 \mathrm{~g} / \mathrm{cm}^{3}$} \\
\hline Absorption coefficient & \multicolumn{2}{|l|}{$0.358 \mathrm{~mm}^{-1}$} \\
\hline$F(000)$ & \multicolumn{2}{|l|}{1296} \\
\hline Crystal size & \multicolumn{2}{|c|}{$0.200 \times 0.200 \times 0.050 \mathrm{~mm}^{3}$} \\
\hline Crystal color and habit & \multicolumn{2}{|l|}{ Yellow Plate } \\
\hline Diffractometer & \multicolumn{2}{|l|}{ Dectris Pilatus 3R } \\
\hline Theta range for data collection & \multicolumn{2}{|l|}{2.904 to $27.484^{\circ}$. } \\
\hline Index ranges & \multicolumn{2}{|c|}{$-19<=\mathrm{h}<=19,-20<=\mathrm{k}<=20,-26<=\mid<=26$} \\
\hline Reflections collected & \multicolumn{2}{|l|}{183492} \\
\hline Independent reflections & \multicolumn{2}{|c|}{$18464[\mathrm{R}(\mathrm{int})=0.1325]$} \\
\hline Observed reflections $(\mathrm{I}>2$ sigma $(\mathrm{I}))$ & \multicolumn{2}{|l|}{14697} \\
\hline Completeness to theta $=25.242^{\circ}$ & \multicolumn{2}{|l|}{$99.8 \%$} \\
\hline Absorption correction & \multicolumn{2}{|c|}{ Semi-empirical from equivalents } \\
\hline Max. and min. transmission & \multicolumn{2}{|c|}{1.00000 and 0.61469} \\
\hline Solution method & \multicolumn{2}{|c|}{ SHELXT-2014/5 (Sheldrick, 2014) } \\
\hline Refinement method & \multicolumn{2}{|c|}{ SHELXL-2014/7 (Sheldrick, 2014) } \\
\hline Data / restraints / parameters & \multicolumn{2}{|l|}{18464 / 0 / 739} \\
\hline Goodness-of-fit on $\mathrm{F}^{2}$ & \multicolumn{2}{|l|}{1.031} \\
\hline Final $R$ indices $[\mid>2$ sigma $(I)]$ & \multicolumn{2}{|c|}{$\mathrm{R} 1=0.0625, \mathrm{wR} 2=0.1589$} \\
\hline $\mathrm{R}$ indices (all data) & \multicolumn{2}{|c|}{$\mathrm{R} 1=0.0791, \mathrm{wR} 2=0.1724$} \\
\hline Largest diff. peak and hole & \multicolumn{2}{|c|}{2.022 and -1.239 e. $\AA^{-3}$} \\
\hline
\end{tabular}


Crystalographic details for 12 . Crystals suitable for XRD were grown by layering a concentrated THF solution of 12 with diethyl ether and storing in a $-40^{\circ} \mathrm{C}$ freezer for 2 days. Low-temperature diffraction data ( $\omega$-scans) were collected on a Rigaku MicroMax-007HF diffractometer coupled to a Dectris Pilatus3R detector with Mo Ka $(\lambda=0.71073 \AA)$. The diffraction images were processed and scaled using Rigaku Oxford Diffraction software. ${ }^{17}$ The structure was solved with SHELXT and was refined against $\mathrm{F}^{2}$ on all data by full-matrix least squares with SHELXL. ${ }^{18}$ All non-hydrogen atoms were refined anisotropically. Hydrogen atoms were included in the model at geometrically calculated positions and refined using a riding model. The isotropic displacement parameters of all hydrogen atoms were fixed to 1.2 times the $U$ value of the atoms to which they are linked (1.5 times for methyl groups). One THF coordinated to the K-18-crown- 6 is disordered over two positions. The site occupancies were freely refined to nearly equal values. All chemically similar $\mathrm{C}-\mathrm{C}$ and $\mathrm{C}-\mathrm{O}$ distances are restrained to be similar. Rigid bond restrains were also used to aid in the refinement of the disordered THF models. The program SQUEEZE was used to compensate for the contribution of disordered solvent contained in voids within the crystal lattice from the diffraction intensities. This procedure was applied to the data file and the submitted model is based on the solvent removed data. Based on the total electron density found in the voids $\left(42 \mathrm{e} / \AA^{3}\right)$, it is likely that $\sim 1 \mathrm{THF}$ molecule is present in the unit cell.
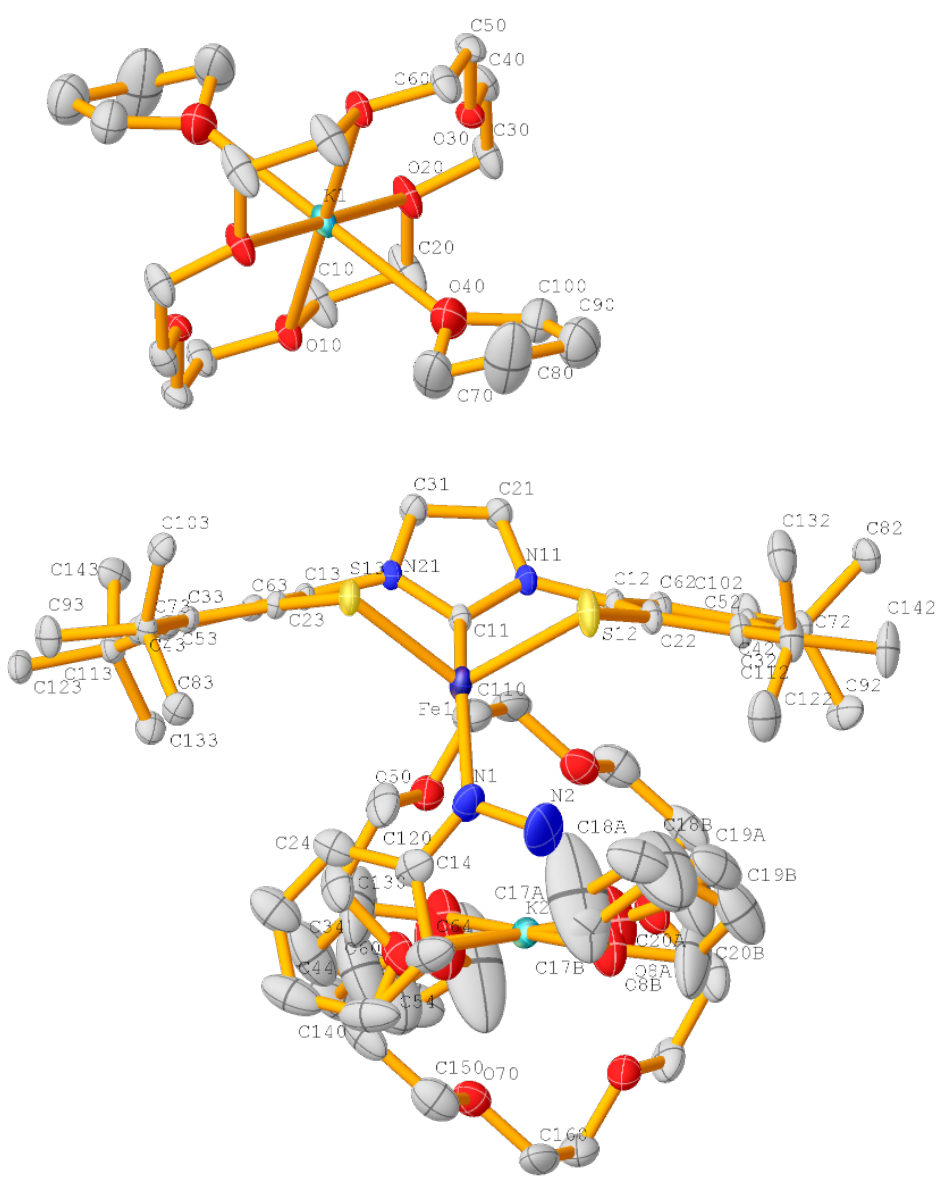

Figure S56. The complete numbering scheme of 12 with 50\% thermal ellipsoid probability levels. Symmetry equivalent atoms are not numbered. The hydrogen atoms are omitted for clarity. 
Table S7. Crystal data and structure refinement for 12.

Identification code

Empirical formula

Formula weight

Temperature

Wavelength

Crystal system

Space group

Unit cell dimensions

Volume

Z

Density (calculated)

Absorption coefficient

$\mathrm{F}(000)$

Crystal size

Crystal color and habit

Diffractometer

Theta range for data collection

Index ranges

Reflections collected

Independent reflections

Observed reflections $(\mathrm{I}>2$ sigma(I))

Completeness to theta $=25.242^{\circ}$

Absorption correction

Max. and min. transmission

Solution method

Refinement method

Data / restraints / parameters

Goodness-of-fit on $\mathrm{F}^{2}$

Final $R$ indices [l>2sigma(I)]

$\mathrm{R}$ indices (all data)

Largest diff. peak and hole 007c-19031

$\mathrm{C} 57 \mathrm{H} 87 \mathrm{Fe} \mathrm{K} \mathrm{N4} \mathrm{O8} \mathrm{S2}$

1115.37

93(2) K

$0.71073 \AA$

Triclinic

$\mathrm{P}-1$

$a=9.9993(4) \AA \quad \alpha=95.243(3)^{\circ}$.

$\mathrm{b}=15.3047(5) \AA \quad \beta=90.884(3)^{\circ}$.

$\mathrm{C}=21.1595(7) \AA \quad \gamma=104.138(3)^{\circ}$.
2

$1.186 \mathrm{~g} / \mathrm{cm}^{3}$

$0.426 \mathrm{~mm}^{-1}$

1196

$0.200 \times 0.040 \times 0.030 \mathrm{~mm}^{3}$

Red Block

Dectris Pilatus $3 R$

2.832 to $27.483^{\circ}$.

$-12<=\mathrm{h}<=12,-19<=\mathrm{k}<=19,-27<=\mathrm{k}<=27$

60808

$14297[R($ int $)=0.0688]$

10967

$99.8 \%$

Semi-empirical from equivalents

1.00000 and 0.19689

SHELXT-2014/5 (Sheldrick, 2014)

SHELXL-2014/7 (Sheldrick, 2014)

14297 / 82 / 719

1.004

$\mathrm{R} 1=0.0524, w R 2=0.1257$

$\mathrm{R} 1=0.0730, w R 2=0.1365$

0.970 and -0.568 e. $\AA^{-3}$ 
Crystalographic details for 13. Crystals suitable for XRD were grown by vapor diffusion of diethyl ether in to a concentrated THF solution of 13 in a $-40{ }^{\circ} \mathrm{C}$ freezer. Low-temperature diffraction data ( $\omega$-scans) were collected on a Rigaku MicroMax-007HF diffractometer coupled to a Saturn994+ CCD detector with $\mathrm{Cu} \mathrm{K \alpha}(\lambda=1.54178 \AA)$. The diffraction images were processed and scaled using Rigaku Oxford Diffraction software. ${ }^{17}$ The structure was solved with SHELXT and was refined against $F^{2}$ on all data by full-matrix least squares with SHELXL. ${ }^{18}$ All non-hydrogen atoms were refined anisotropically. Hydrogen atoms were included in the model at calculated positions and refined using a riding model. The isotropic displacement parameters of all hydrogen atoms were fixed to 1.2 times the $U$ value of the atoms to which they are linked (1.5 times for methyl groups). The only exception is $\mathrm{H} 14$, which was found in the difference map and freely refined. One tert-butyl group and a THF were modeled as disordered. The minor component of both models required that the thermal parameters be constrained to identical values of their major counterparts. The 1,2 $\mathrm{C}-\mathrm{C}$ and $\mathrm{C}-\mathrm{O}$ distances were restrained to be similar. The tert-butyl group required $1,3 \mathrm{C}$-C distance restraints.

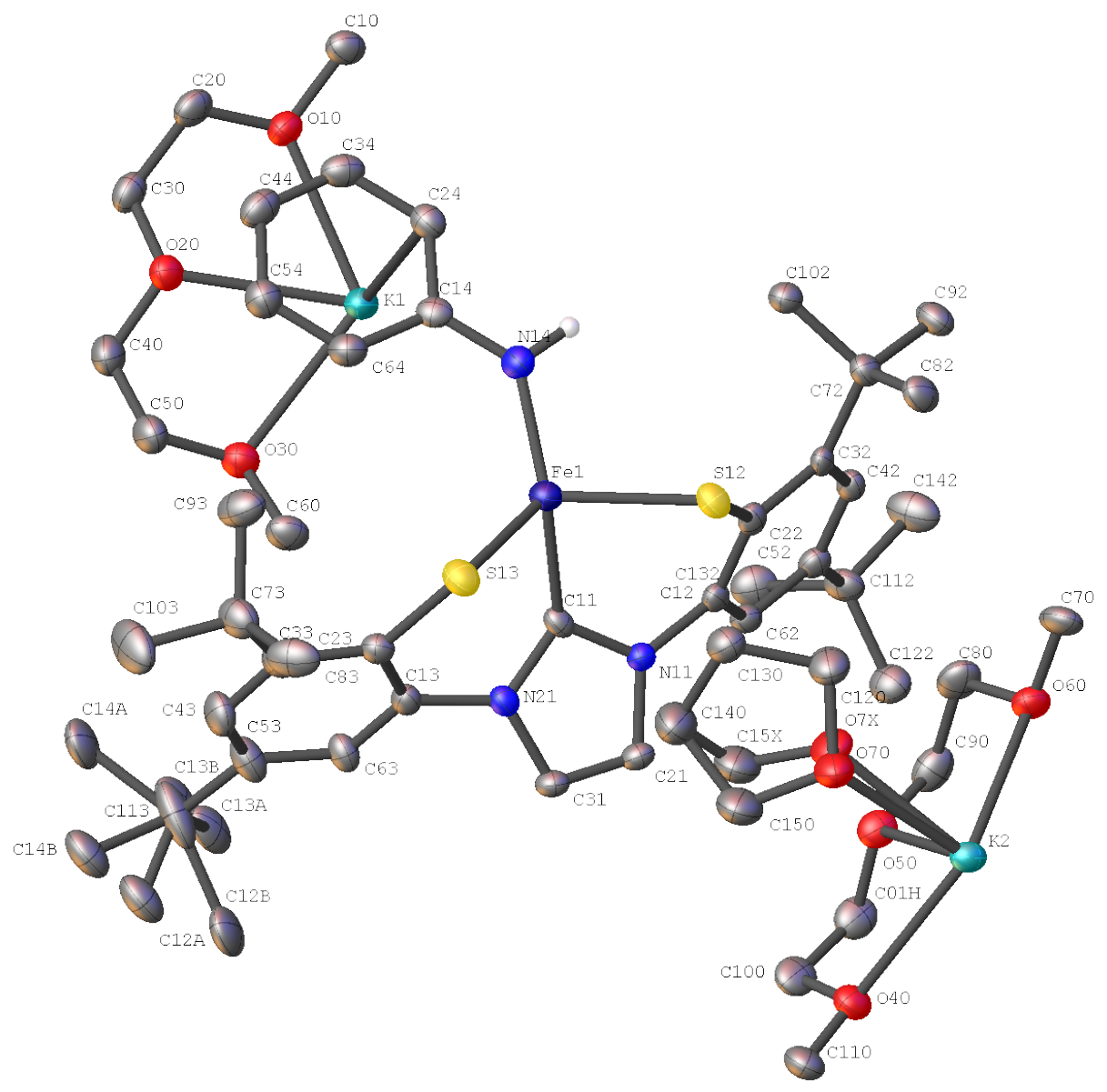

Figure S57. The complete numbering scheme of 13 with $50 \%$ thermal ellipsoids, with the major conformer of disordered groups. The hydrogen atoms, except $\mathrm{H} 14$, are not shown for clarity. 
Table S8. Crystal data and structure refinement for 13.

\begin{tabular}{|c|c|c|}
\hline Identification code & \multicolumn{2}{|l|}{ 007b-19057 } \\
\hline Empirical formula & \multicolumn{2}{|c|}{ C53 H80 Fe K N3 O7 S2 } \\
\hline Formula weight & \multicolumn{2}{|l|}{1030.27} \\
\hline Temperature & \multicolumn{2}{|l|}{$93(2) \mathrm{K}$} \\
\hline Wavelength & \multicolumn{2}{|l|}{$1.54184 \AA$} \\
\hline Crystal system & \multicolumn{2}{|l|}{ Triclinic } \\
\hline Space group & \multicolumn{2}{|l|}{$P-1$} \\
\hline \multirow[t]{3}{*}{ Unit cell dimensions } & $a=9.9424(4) \AA$ & $\alpha=101.205(3)^{\circ}$ \\
\hline & $b=16.8415(6) \AA$ & $\beta=101.212(3)^{\circ}$ \\
\hline & $c=18.7422(7) \AA$ & $\gamma=98.457(3)^{\circ}$ \\
\hline Volume & \multicolumn{2}{|l|}{$2963.5(2) \AA^{3}$} \\
\hline Z & \multicolumn{2}{|l|}{2} \\
\hline Density (calculated) & \multicolumn{2}{|l|}{$1.155 \mathrm{~g} / \mathrm{cm}^{3}$} \\
\hline Absorption coefficient & \multicolumn{2}{|l|}{$3.699 \mathrm{~mm}^{-1}$} \\
\hline$F(000)$ & \multicolumn{2}{|l|}{1104} \\
\hline Crystal size & \multicolumn{2}{|c|}{$0.200 \times 0.200 \times 0.020 \mathrm{~mm}^{3}$} \\
\hline Crystal color and habit & \multicolumn{2}{|l|}{ Yellow Plate } \\
\hline Diffractometer & \multicolumn{2}{|c|}{ Rigaku Saturn 944+ CCD } \\
\hline Theta range for data collection & \multicolumn{2}{|l|}{2.469 to $66.597^{\circ}$} \\
\hline Index ranges & \multicolumn{2}{|c|}{$-11<=\mathrm{h}<=11,-20<=\mathrm{k}<=20,-22<=\mid<=22$} \\
\hline Reflections collected & \multicolumn{2}{|l|}{69563} \\
\hline Independent reflections & \multicolumn{2}{|c|}{$10250[R($ int $)=0.0946]$} \\
\hline Observed reflections $(\mathrm{I}>2$ sigma $(\mathrm{I}))$ & \multicolumn{2}{|l|}{7822} \\
\hline Completeness to theta $=66.597^{\circ}$ & \multicolumn{2}{|l|}{$97.8 \%$} \\
\hline Absorption correction & \multicolumn{2}{|c|}{ Semi-empirical from equivalents } \\
\hline Max. and min. transmission & \multicolumn{2}{|c|}{1.00000 and 0.57460} \\
\hline Solution method & \multicolumn{2}{|c|}{ SHELXT-2014/5 (Sheldrick, 2014) } \\
\hline Refinement method & \multicolumn{2}{|c|}{ SHELXL-2014/7 (Sheldrick, 2014) } \\
\hline Data / restraints / parameters & \multicolumn{2}{|l|}{10250 / 45 / 649} \\
\hline Goodness-of-fit on $\mathrm{F}^{2}$ & \multicolumn{2}{|l|}{1.096} \\
\hline Final $R$ indices $[\mid>2$ sigma $(I)]$ & \multicolumn{2}{|c|}{$\mathrm{R} 1=0.0537, w R 2=0.1319$} \\
\hline $\mathrm{R}$ indices (all data) & \multicolumn{2}{|c|}{$\mathrm{R} 1=0.0738, w R 2=0.1505$} \\
\hline Largest diff. peak and hole & \multicolumn{2}{|c|}{0.602 and -0.423 e. $\AA^{-3}$} \\
\hline
\end{tabular}




\section{References}

(1) Hagen, K. S. Iron(II) triflate salts as convenient substitutes for perchlorate salts: crystal structures of $\left[\mathrm{Fe}\left(\mathrm{H}_{2} \mathrm{O}\right)_{6}\right]\left(\mathrm{CF}_{3} \mathrm{SO}_{3}\right)_{2}$ and $\mathrm{Fe}(\mathrm{MeCN})_{4}\left(\mathrm{CF}_{3} \mathrm{SO}_{3}\right)_{2}$. Inorg. Chem. 2000, 39, 5867-5869.

(2) Broere, D. L.; Coric, I.; Brosnahan, A.; Holland, P. L. Quantitation of the THF Content in Fe[N( $\left.\left.\mathrm{SiMe}_{3}\right)_{2}\right]_{2}$ - xTHF. Inorg. Chem. 2017, 56, 3140-3143.

(3) Dresselhaus, M. S.; Dresselhaus, G. Intercalation compounds of graphite. Adv. Phys. 1981, 30, 139326.

(4) Mallow, O.; Khanfar, M. A.; Malischewski, M.; Finke, P.; Hesse, M.; Lork, E.; Augenstein, T.; Breher, F.; Harmer, J. R.; Vasilieva, N. V.; Zibarev, A.; Bogomyakov, A. S.; Seppelt, K.; Beckmann, J. Diaryldichalcogenide radical cations. Chem. Sci. 2015, 6, 497-504.

(5) Brookhart, M.; Grant, B.; Volpe, A. F. [(3,5- $\left.\left.\left(\mathrm{CF}_{3}\right)_{2} \mathrm{C}_{6} \mathrm{H}_{3}\right)_{4} \mathrm{~B}\right]\left[\mathrm{H}\left(\mathrm{OEt}_{2}\right)_{2}\right]^{+}$: a convenient reagent for generation and stabilization of cationic, highly electrophilic organometallic complexes. Organometallics 1992, 11, 3920-3922.

(6) Chalkley, M. J.; Del Castillo, T. J.; Matson, B. D.; Roddy, J. P.; Peters, J. C. Catalytic $\mathrm{N}_{2}$-to-NH $\mathrm{NH}_{3}$ Conversion by Fe at Lower Driving Force: A Proposed Role for Metallocene-Mediated PCET. ACS Cent. Sci. 2017, 3, 217-223.

(7) McCarthy, B. D.; Martin, D. J.; Rountree, E. S.; Ullman, A. C.; Dempsey, J. L. Electrochemical reduction of Bronsted acids by glassy carbon in acetonitrile-implications for electrocatalytic hydrogen evolution. Inorg. Chem. 2014, 53, 8350-8361.

(8) Sellmann, D.; Käppler, O. Transition Metal Complexes with Sulfur Ligands, XXXII: Synthesis of the Sterically Demanding New Thiolate-amine Ligands tbuz-ma-H = 2-Mercapto-3,5-di-tbutylaniline and ${ }^{t} b_{4}-b_{\text {bmae- }} \mathrm{H}_{2}=1,2-\mathrm{Bis}(2-$ mercapto-3,5-di-tbutylanilino)ethane as well as of their Iron-, Ruthenium- and

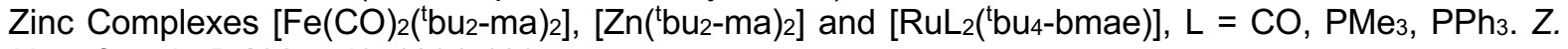
Naturforsch. B 1987, 42, 1291-1297.

(9) Téllez, F.; Cruz, A.; López-Sandoval, H.; Ramos-García, I.; Gayosso, M.; Castillo-Sierra, R. N.; PazMichel, B.; Nöth, H.; Flores-Parra, A.; Contreras, R. Dithiocarbamates, Thiocarbamic Esters, Dithiocarboimidates, Guanidines, Thioureas, Isothioureas, and Tetraazathiapentalene Derived from 2Aminobenzothiazole. Eur. J. Org. Chem. 2004, 4203-4214.

(10) Shaban, S. Y.; Ibrahim, M. M.; Heinemann, F. W. A new sterically loaded pentadentate $\mathrm{N}_{3} \mathrm{~S}_{2}$ ligand and its zinc complexes. Inorg. Chim. Acta. 2007, 360, 2929-2934.

(11) Lee, S.; Jorgensen, M.; Hartwig, J. F. Palladium-catalyzed synthesis of arylamines from aryl halides and lithium bis(trimethylsilyl)amide as an ammonia equivalent. Org. Lett. 2001, 3, 2729-2732.

(12) Surry, D. S.; Buchwald, S. L. Selective palladium-catalyzed arylation of ammonia: synthesis of anilines as well as symmetrical and unsymmetrical di- and triarylamines. J. Am. Chem. Soc. 2007, 129, 1035410355.

(13) Ghosh, P.; Begum, A.; Bill, E.; Weyhermuller, T.; Wieghardt, K. Molecular and electronic structures of iron(II)/(III) complexes containing N,S-coordinated, closed-shell o-aminothiophenolato(1-) and oiminothiophenolato(2-) ligands. Inorg. Chem. 2003, 42, 3208-3215.

(14) Despagnet-Ayoub, E.; Miqueu, K.; Sotiropoulos, J.-M.; Henling, L. M.; Day, M. W.; Labinger, J. A.; Bercaw, J. E. Unexpected rearrangements in the synthesis of an unsymmetrical tridentate dianionic Nheterocyclic carbene. Chem. Sci. 2013, 4, 2117-2121.

(15) Chaney, A. L.; Marbach, E. P. Modified Reagents for Determination of Urea and Ammonia. Clin. Chem. $1962,8,130-132$.

(16) Watt, G. W.; Chrisp, J. D. Spectrophotometric Method for Determination of Hydrazine. Anal. Chem. 1952, 24, 2006-2008.

(17) CrysAlisPro, Rigaku OD: Woodlands, TX, 2015.

(18) Sheldrick, G. M. A Short History of SHELX. Acta Cryst. 2008, A64, 112-122. 